\title{
COMPORTAMENTO FENOLÓGICO DAS PRINCIPAIS CULTIVARES DE Q Qitis vinifera L. PARA A REGIÃO DE BENTO GONÇALVES, RS
}

\section{FRANCISCO MANDELLI}

Orientador: Dr. AFONSO DECICO

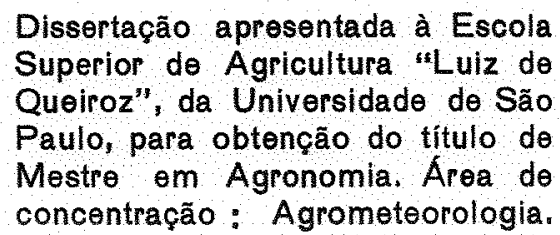

$P \mid R A C I C A B A$

Estado de São Paulo - Brasil Julho - 1984 
A memöria de meu pai, Alfredo A minha mãe, Anuncia

A meus irmãos e irmãs

D E D I C O 


\section{AGRADECIMENTOS}

A Secretaria da Agricultura do Estado do Rio Grande do Sul, à EMBRAPA e à Escola Superior de Agricultura "Luiz de Queiroz" pe la oportunidade de realização do curso.

Ao Prof. Dr. Afonso Decico, pela orientação e amizade.

Aos Profs. Luiz Roberto Angelocci (ESALQ), Homero Bergamaschi (UFRGS) e Sērgio Luiz Westphalen (SA/UFRGS) pela colaboração, apoio e amizade.

Aos professores do Departamento de Física e Meteorologia da ESALQ, que contribuíram para minha formação profissional.

Ao Chefe da UEPAE/BG, Dr. João Giugliani Filho e ao Dire tor da Estação Experimental de Vitivinicultura de Caxias do Sul, Dr. Jaime Luis Lovatel pelo estímulo e apoio na realização do curso.

Aos colegas da Estação Experimental de Vitivinicultura de Caxias do Sul, Moacyr Falcão Dias e Amaury F. Dal Conte e aos da UEPAE/BG pelo incentivo e por assumirem minhas atividades possibilitaram o meu afastamento para a realização do curso.

A UEPAE de Bento Gonçalves, Instituto Nacional de Meteorologia - INMET/MA, através do 89 DISME e à Seção de Ecologia Agrícola do IPAGRO pela cedencia dos dados.

Ao Convento EMBRAPA-Secretaria da Agricultura do Rio Grande do Sul pelo auxilio financeiro.

A Ana Rita F. Rodrigues, Hamilton J. Vieira, Renato dos 
Santos e Sara Maria S. da Igreja e demais colegas do Curso de Agrometeorologia pelo convivio e amizade.

- As funcionārias do Departamento de Física e Meteorologia Aurea B. Michelotto e Ana M.S. Michelon pela amizade e colaboração durante o curso.

A todos que de uma forma ou de outra contribuíram para a realização deste trabalho. 


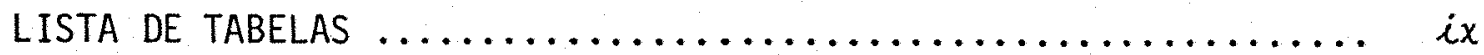

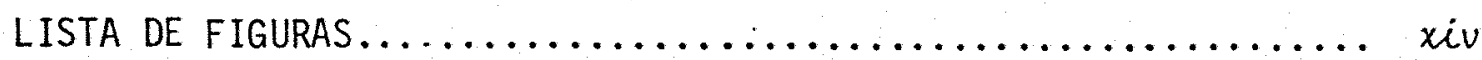

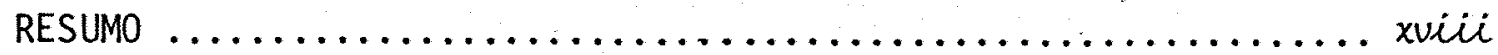

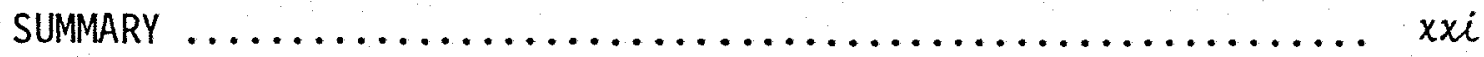

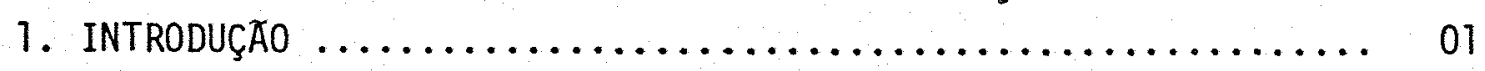

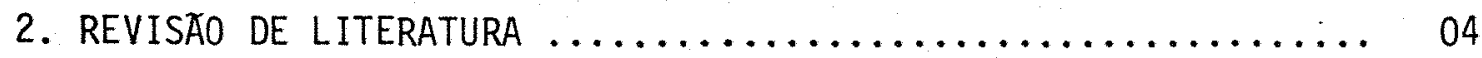

2.1. Clima e distribuição da videira ................. 04

2.2. Fenologia da videira ............................ 08

2.2.1. Ciclo vegetativo $\ldots \ldots \ldots \ldots \ldots \ldots \ldots \ldots \ldots \ldots \ldots$

2.2.2. Repouso hibernal $\ldots \ldots \ldots \ldots \ldots \ldots \ldots \ldots \ldots .10$

2.2.2.1. Fase de pré-dormēncia $\ldots \ldots \ldots \ldots \ldots \ldots, 12$

2.2.2.2. Fase de entrada em dormência ........ 13

2.2.2.3. Fase de dormência ............... 14

2.2.2.4. Fase da quebra de dormência ......... 14

2.2.2.5. Fase de pōs-dormência $\ldots \ldots \ldots \ldots \ldots \ldots .15$

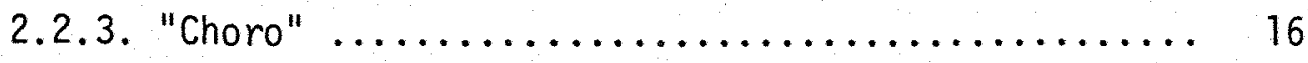

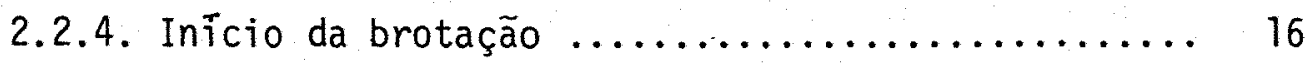

2.2.5. Crescimento dos ramos $\ldots \ldots \ldots \ldots \ldots \ldots \ldots \ldots, 17$

2.2.6. Florescimento $\ldots \ldots \ldots \ldots \ldots \ldots \ldots \ldots \ldots \ldots \ldots, 18$

2.2.7. Maturação $\ldots \ldots \ldots \ldots \ldots \ldots \ldots \ldots \ldots \ldots \ldots \ldots \ldots \ldots$

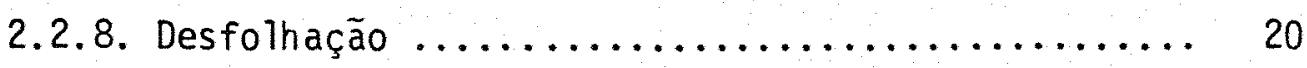

2.2.9. Amadurecimento dos tecidos $\ldots \ldots \ldots \ldots \ldots \ldots \ldots 20$ 
päg.

2.3. Elementos e fatores do clima e o desenvolvimento da vi

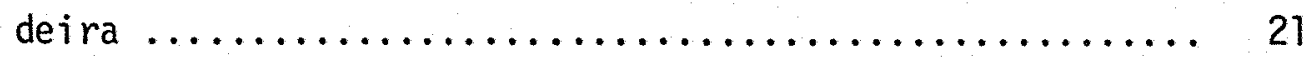

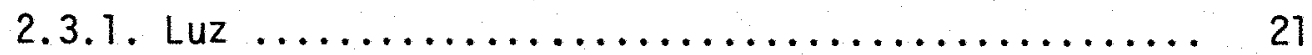

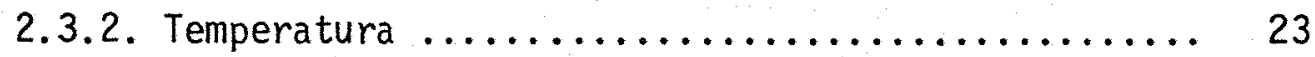

2.3.3. Regime hidrico $\ldots \ldots \ldots \ldots \ldots \ldots \ldots \ldots \ldots .27$

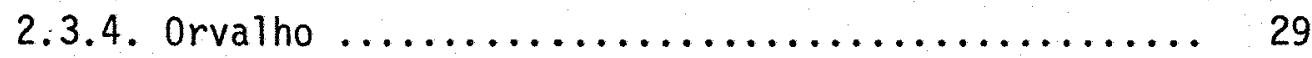

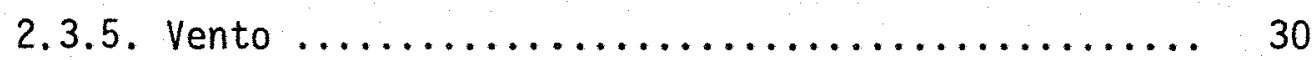

2.3.6. Fatores geogräficos ................... 30

2.3.6.1. Latitude ..................... 30

2.3.6.2. Altitude $\ldots \ldots \ldots \ldots \ldots \ldots \ldots \ldots \ldots . .31$

2.3.6.3. Relevo e exposição ............... 32

2.3.6:4. Florestas ................... 32

2.3.6.5. Proximidades de massas d'āgua ........ 32

2.4. Parâmetros de caracterização das exigências climāticas

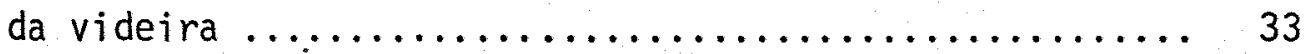

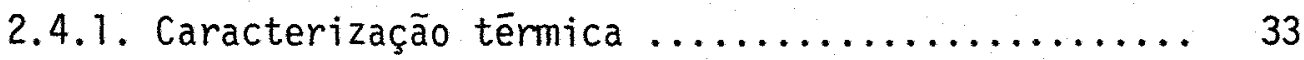

2.4.1.1. Zero de vegetação (temperatura-base) ... 34

2.4.1.2. Período ativo $\ldots \ldots \ldots \ldots \ldots \ldots \ldots \ldots, 36$

2.4.1.3. Temperatura ativa $\ldots \ldots \ldots \ldots \ldots \ldots \ldots, 36$

2.4.1.4. Graus-dia ................... 37

2.4.2. Caracterização hel iotērmica ............... 39

2.4.3. Caracterização hidrotérmica e o desenvolvimento

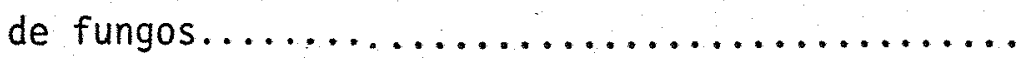


2.4.4. Caracterização heliohidrotérmica $\ldots . \ldots \ldots \ldots \ldots .42$

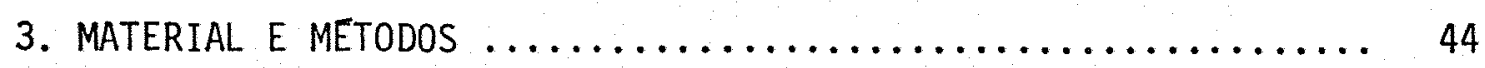

3.1. Clima e Solo ............................. 44

3.1.1. Caracterização do clima da Microrregião Homogēnea 311 - Vinicultora de Caxias do Sul (MRH311) _ 44

3.1.2. Caracterização do solo da MRH311 ........... 46

3.2. Dados meteorológicos $\ldots \ldots \ldots \ldots \ldots \ldots \ldots \ldots \ldots . \ldots . \ldots . \ldots$

3.3. Dados fenológicos ............................. 47

3.4. Determinações fenológicas $\ldots \ldots \ldots \ldots \ldots \ldots \ldots \ldots \ldots . \ldots . \ldots . \ldots$

3.4.1. Início ao final da brotação (IB-FB) $\ldots \ldots \ldots \ldots .49$

3.4.2. Inĩcio ao final da floração (IF-FF) $\ldots \ldots \ldots \ldots .49$

3.4.3. Início ao final da maturação (IM-FM) ........ 50

3.4.4. Início ao final da queda das folhas (IQF-FQF) ... 50

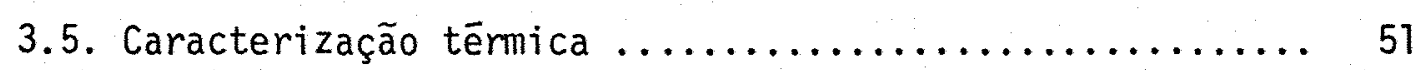

3.5.1. Tempera.tura-base e graus-dia .............. 51

3.5.2. Temperatura ativa $\ldots \ldots \ldots \ldots \ldots \ldots \ldots \ldots \ldots \ldots \ldots$

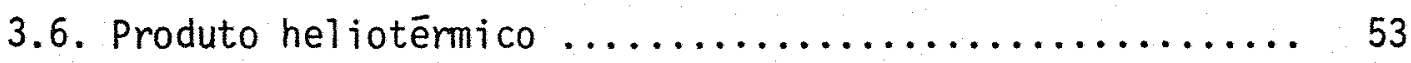

3.7. Coeficiente hidrotérmico para o desenvolvimento de

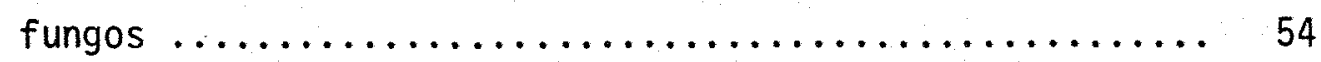

3.8. Caracterização heliohidrotérmica $\ldots \ldots \ldots \ldots \ldots \ldots . . \ldots 54$

3.8.1. Indice bioclimātico de Constantinescu ......... 54

3.8.2. Quociente heliopluviomētrico de maturação $\ldots . . .55$ 
viii

Pāg.

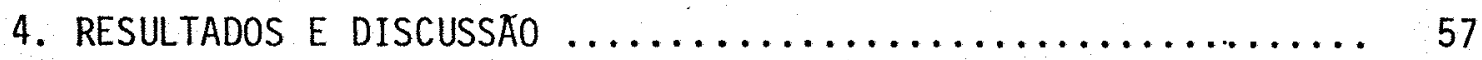

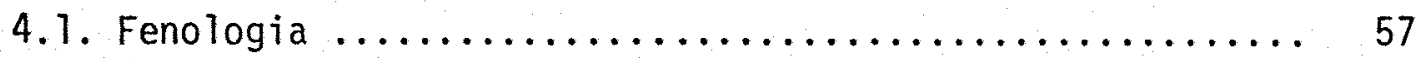

4.1.1. Inīcio ao final da brotação (IB-FB) ........ 57

4.1.2. Inīcio ao final da floração (IF-FF) ....... 73

4.1.3. Início ao final da maturação (IM-FM) ....... 75

4.1.4. Início ao final da queda das folhas (IQF-FQF) ... 78

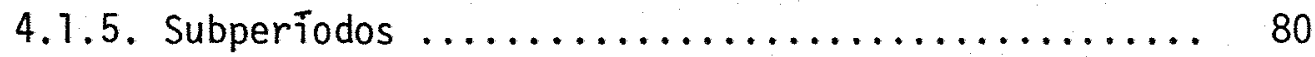

4.1.6. Comparação fenolōgica entre a cultivar Cabernet franc e as demais cultivares em estudo ....... 84

4.2. Caracterização térmica $\ldots \ldots \ldots \ldots \ldots \ldots \ldots \ldots \ldots \ldots \ldots$

4.2.1. Temperatura-base $\ldots \ldots \ldots \ldots \ldots \ldots \ldots \ldots \ldots$

4.2.2. Graus-dia ...................... 93

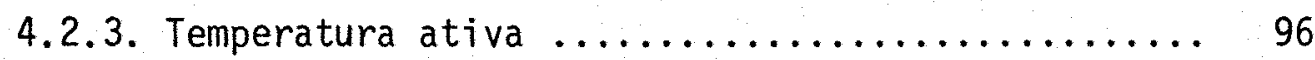

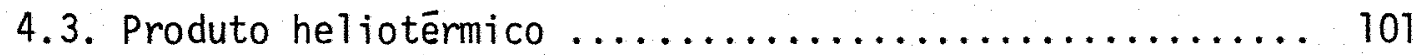

4.4. Coeficiente hidrotérmico para o desenvolvimento de

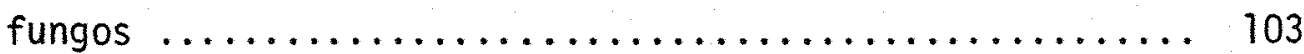

4.5. Caracterização heliohidrotērmica ............. 105

4.5.1. Indice bioclimätico de Constantinescu ........ 105

4.5.2. Quociente heliopluviométrico de maturação ..... 107

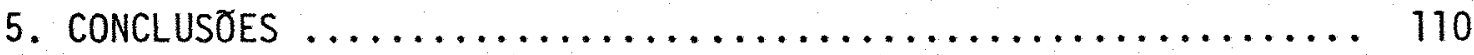

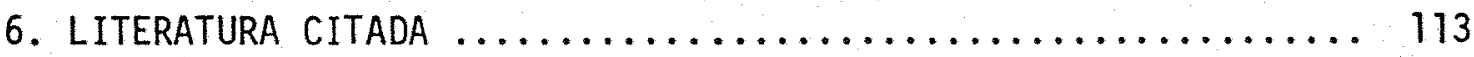




\section{LISTA DE TABELAS}

Tabela nọ Pāg.

01 Dados climāticos (mēdias mensais, médias anuais

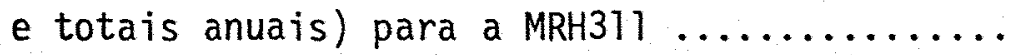

02 Datas médias de ocorrēncia das diferentes fases fenológicas e respectivos intervalos de confian ça em dias $(\alpha=0,05)$ de 11 cultivares de videi ra. Bento Gonçalves, $1965 / 78$...............

03 Número médio de dias para a ocorrência dos dife rentes subperiodos fenológicos (do início ao fi nal da brotação, floração, maturação e queda das folhas) com respectivas amplitudes e coefi cientes de variação de 11 cultivares de videira. Bento Gonçalves, $1965 / 78$.................

04 Datas de ocorrência do início da brotação (ano, mês e dia) de 11 cultivares de videira e respec tivos graus-dia acumulados ( $\Sigma G D$ ) acima da tempe ratura-base de $12^{\circ} \mathrm{C}$ durante o período de 10 de maio a 15 de junho. Bento Gonçalves, 1965/78 .. 
Pāg.

05 Número de dias médio para a ocorrēncia dos di ferentes subperiodos fenológicos (IB = início da brotação; IF = inīcio da floração; IM = início da maturação; $F M=$ final da maturação; $F F=f i-$ nal da floração; IQF = inĩcio da queda das foThas; $F Q F=$ final da queda das fol has) e os res pectivos intervalos de confiança, em dias $(\alpha=$ 0,05), amplitude (em dias) e coeficientes de va riação (\%) de 11 cultivares de videira. Bento Gonçalves, $1965 / 78 \ldots \ldots \ldots \ldots \ldots \ldots \ldots \ldots$

06 Desvios (nọ de dias) nas datas médias de ocorrência dos diferentes estādios fenolōgicos das cultivares estudadas em relação à cv. Cabernet franc. Bento Gonçalves, 1965/78 ...........

07 Somatório de graus-dia, no subperíodo início da brotação - final da maturação, calculados com diferentes temperaturas-base e respectivas equa ções de regressão e coeficientes de correlação (r), na cv. Cabernet franc. Bento Gonçalves,

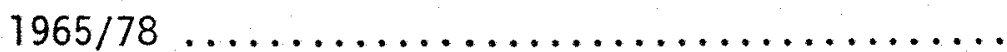

08 Valores da temperatura média $\left({ }^{\circ} \mathrm{C}\right)$, do nümero de dias (N), do desvio padrão da soma térmica expresso em dias ( $S d$ ) e em graus-dia ( $S d d$ ) e tem 
Pàg.

peraturas-base correspondentes, para o subperío do inĩcio da brotação - final da maturação da cultivar Cabernet franc, durante alguns anos a-

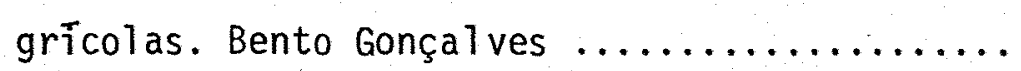

09 Datas (ano, mês e dia) de ocorrência do inīcio da brotação (IB) de 11 cultivares de videira e os respectivos zero de vegetação $\left(T 0^{\circ}\right)$, em ${ }^{\circ} \mathrm{C}$, média, erro padrão da média $(s(\hat{m}))$ e intervalos de confiança (I.C.). Bento Gonçalves, 1965/78.

10 Graus-dia acumulados para a temperatura-base de $12^{\circ} \mathrm{C}$ durante as fases fenolögicas brotação, flo ração, maturação e o total acumulado com os res pectivos coeficientes de variação (C.V.), erro padrão da média $(s(\bar{m}))$, intervalo de confiança (I.C.) e valores extremos para o subperiodo in i cio da brotação - final da maturação (IB-FM) pa ra 11 cultivares de videira. Bento Gonçalves,

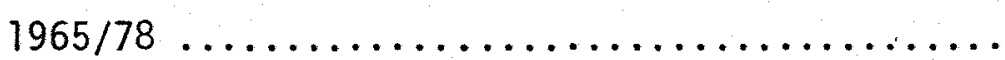

11 Temperatura ativa acumulada para a temperatura-base de $12^{\circ} \mathrm{C}$ durante as fases fenolögicas brotação, floração, maturação e o total acumulado com os respectivos coeficientes de variação ( $C$. V.), erro padrão da média $(s(\hat{m}))$, intervalo de 
Pāg.

confiança (I.C.) e valores extremos para o subperíodo início da brotação - final da maturação (IB-FM) para 11 cultivares de videira. Bento

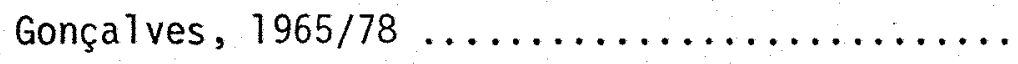

12 Número de dias e valores médios do somatório dos graus-dia $(\Sigma G D)$ e temperatura ativa ( $\Sigma T a)$ para o subperíodo início da brotação - final da matu ração (IB-FM) de 10 cultivares de videira. Ben to Gonçalves, $1965 / 78 \ldots \ldots \ldots \ldots \ldots \ldots \ldots$

13 Produto Heliotérmico (P.H.) durante as fases fe nolōgicas brotação, floração, maturação e o total acumulado com a respectiva média, coeficien te de variação e erro padrão da média para 0 subperíodo início da brotação - final da matura ção (IB-FM) para 11 cultivares de videira. Ben to Gonçalves, $1965 / 78 \ldots \ldots \ldots \ldots \ldots \ldots \ldots$

14 Coeficiente Hidrotērmico (C.H.) acumulado, com as respectivas médias, coeficiente de variação, erro padrão da média e intervalo de confiança para o subperíodo início da brotação - final da maturação para 11 cultivares de videira, nos a- 
Pāg.

nos agrícolas de 1965/66, 1967/68, 1969/70, 1972/73 e 1977/78. Bento Gonçalves ...........

15 Indice bioclimātico (Ibc) acumulado, com as res pectivas médias, coeficiente de variação, erro padrão da média e intervalo de confiança para o subperĩodo início da brotação - final da matura ção para 11 cultivares de videira, nos anos agrícolas de 1965/66, 1967/68, 1969/70,1972/73

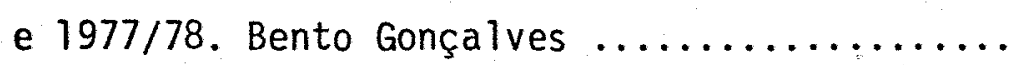

16 Quociente Heliopluviométrico de Maturação (Q.M.) acumulado, com as respectivas mëdias e erro pa drão da média, para o subperíodo início da bro tação - final da maturação, para 11 cultivares de videira nos anos agrícolas de 1965/66, 1967/ $68,1969 / 70,1972 / 73$ e 1977/78. Bento Gonçalves 


\section{LISTA DE FIGURAS}

Figura nọ Pāg.

01 Datas e número mëdics de dias com respectivos in tervalos de confiança necessārios para a realiza ção das fases fenológicas (inîcio e final) brota ção, floração, maturação e queda das folhas, em 11 cultivares de videira. Bento Gonçalves, 1965/

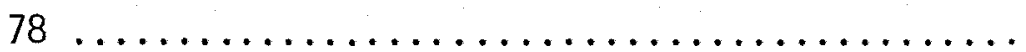

02 Número médio de dias com os respectivos intervalos de confiança necessārios para a realização das fases fenolōgicas brotação, floração, matura ção e queda das folhas, em 11 cultivares de videira. Bento Gonçalves, 1965/78 ..........

03 Datas de ocorréncia dos estädios fenolōgicos in cio da brotação (IB), final da brotação (FB), inīcio da floração (IF), final da floração (FF), inĩcio da maturação (IM), final da maturação (FM), início da queda das folhas (IQF) e final da queda das folhas (FQF) para as cultivares semillon e Barbera. Bento Gonçalves, 1965/78 ..........

04 Datas de ocorrência dos estädios fenolōgicos in cio da brotação (IB), final da brotação (FB), início da floração (IF), final da floração (FF), 
Pāg.

inīcio da maturação (IM), final da maturação (FM), início da queda das folhas (IQF) e final da queda das folhas (FQF) para as cultivares Bonarda e Merlot. Bento Gonçalves, 1965/78 .............

05 Datas de ocorrência dos estádios fenológicos inî cio da brotação (IB), final da brotação (FB), início da floração (IF), final da floração (FF), inīcio da maturação (IM), final da maturação (FM), início da queda das folhas (IQF) e final da queda das folhas (FQF) para as cultivares Cabernet franc e Petit Syrah. Bento Gonçalves, 1965/78 .. Datas de ocorrência dos estādios fenotógicos iní cio da brotação (IB), final da brotação (FB), inīcio da floração (IF), final da floração (FF), inīcio da maturação (IM), final da maturação (FM), início da queda das folhas (IQF) e final da queda das folhas (FQF) para as cultivares Riesling itālico e Trebbiano. Bento Gonçalves, 1965/78 ..

07 Datas de ocorrēncia dos estādios fenológicos iní cio da brotação (IB), final da brotação (FB), inĩcio da floração (IF), final da floração (FF), inî́cio da maturação (IM), final da maturação (FM), 
Pāg.

inicio da queda das folhas (IQF) e final da queda das folhas (FQF) para as cultivares Malvasia de Lipari e Moscatel branco. Bento Gonçalves,

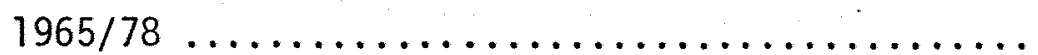

08 Datas de ocorrēncia dos estádios fenológicos iní cio da brotação (IB), final da brotação (FB), início da floração (IF), final da floração (FF), início da maturação (IM), final da maturação (FM), início da queda das folhas (IQF) e final da queda das folhas (FQF) para a cultivar Isabel. Ben ta Gonçalves, $1973 / 78 \ldots \ldots \ldots \ldots \ldots \ldots \ldots \ldots .70$

09 Esquema do ritmo vegetativo da videira ......... 83

10.a Graus-dia acumulados obtidos em função da temperatura-base, no subperíodo início da brotação - fi nal da maturação, para a cultivar Cabernet franc.

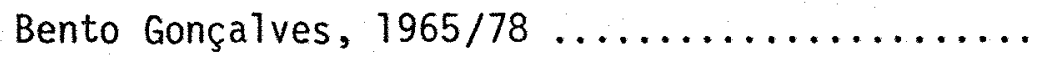

10.b Graus-dia acumulados obtidos em função da temperatura-base, no subperíodo início da brotação - f $\underline{j}$ nal da maturação, para a cultivar Cabernet franc nos sete anos agrícolas selecionados .......... 
Pàg.

11 Nūmero de dias necessārios para o subperiodo inî cio da brotação - final da maturação da cultivar Cabernet franc em função da temperatura média do ar. Bento Gonçalves, 1965/78

12 Desvio padrão (em dias) em função de temperaturas-base entre 4 a $16^{\circ} \mathrm{C}$, para o subperiodo início da brotação - final da maturação na cultivar Cabernet franc. Bento Gonçalves ............. 
COMPORTAMENTO FENOLOGICO DAS PRINCIPAIS CULTIVARES DE Vit is vinifera L. PARA A REGIÁO DE BENTO GONÇALVES

Candidato: Francisco Mandelli

Orientador: Prof. Dr. Afonso Decico

RES U M O

0 presente estudo teve como objetivos caracterizar o padrão fenológico médio, quantificar as necessidades térmicas e heliotérmicas, bem como caracterizar as potencialidades viticolas da região de Bento Gonçalves no que se refere à aptidão climática.

Para isso utilizaram-se os dados meteorológicos e fenológicos de uma série de 13 anos (1965/78), coletados na UEPAE de Bento Gonçalves, situada a $29^{\circ} 15^{\prime}$ de latitude sul, $51^{\circ} 31^{\prime}$ de longitu de oeste e altitude de $671 \mathrm{~m}$.

As cultivares estudadas foram selecionadas ou por serem as de maior expressão econômica dentro de seus grupos ou por apresentarem uma boa perspectiva à difusão na Microrregião Homogênea 311 - Vinicultora de Caxias do SuI (MRH311). 
A descrição dos estädios fenolögicos proposta por AZZI (1959) foi tomada como base para a determinação da fenologia mé dia de 11 cultivares de videira, sendo 10 de origem europèia (Vitis vinifera L.) e uma anericana (Vitis labrusca L.). As cultivares Isa bel e Semilion apresentaram brotação mais precoce, a cv. Moscatel branco mais tardia, sendo de brotação intermediäria as cvs. Cabernet franc, Bonarda, Riesling itálico, Merlot, Barbera, Trebbiano, Petit Syrah e Malvasia de Lipari. A sequência nas datas de ocorrēncia da floração mostrou um comportamento semelhante ao da brotação. Quanto à data média de maturação, as cvs. Riesling itälico, SemilIon, Trebbiano, Isabel e Bonarda demonstraram pertencer ao 39 grupo da escala de Pulliat, enquanto as demais cultivares demonstraramper tencer ao 49 grupo.

As necessidades tērmicas e heliotērmicas exigidas pe las diversas cultivares atē atingir a maturação foram determinadas através do somatörio de graus-dia, temperatura ativa e produto heliotérmico; para as cultivares extremas foram necessärios, em média, respectivamente, $1299 \mathrm{GD}, 3087^{\circ} \mathrm{C}$ e 2,59 para a cv. Ries ling itälico e $1427 \mathrm{GD}, 3411^{\circ} \mathrm{C}$ e 3,17 para a cv. Cabernet franc. Esses va lores mostraram que a região apresentou condições térmicas e heliotërmicas dentro dos limites exigidos para outras regiões vitícolas tradicionais. No cälculo destes indices, considerou-se a temperatura-base de $12^{\circ} \mathrm{C}$ para todo o ciclo. 
As possibilidades para a incidencia de molēstias füngicas, durante o período vegetativo da videira, foram avaliadas atra vés do coeficiente hidrotérmico de ZULUAGA et alii (1971). Utilizou-se o indice bioclimático de CONSTANTINESCU (1967) para relacionar as disponibilidades de temperatura e luz com as dispcribilidades de àgua. Estes indices mostraram que a região apresentou umidade excessiva em todos os anos, uma vez que os valores, calculados excederamos limites estabelecidos para outras regióes vitícolas.

0 quociente heliopluviomëtrico de maturação proposto por WESTPHALEN (1977), que avalia as condições para a maturação das uvas desde a mudança de cor à colheita, mostrou que, embora a umidade possa ser considerada excessiva, existiram, em alguns anos, condi ções para a obtenção de uvas de bo a qualidade para a vinificação. 


\section{PHENOLOGICAL BEHAVIOR OF MAJOR CULTIVARS OF Vitis vinifera} L. FOR THE BENTO GONÇALVES REGION

Author: Francisco Mande11i

Adviser: Afonso Decico

The aim of the present study was to characterize the mean phenological standard, quantify thermal and heliothermal requirements and characterize the viticultural potencialities for the Bento Gonçalves region, regarding climatic aptitude.

To this purpose, phenological and meteorological data were utilized from a series of 13 years (1965-1978), collected at the UEPAE in Bento Gonçalves (RS), located at $29^{\circ} 15^{\prime} \mathrm{S}$ latitude, $51^{\circ} 31^{\prime} \mathrm{W}$ longitude and altitude $671 \mathrm{~m}$.

The cultivars selected for study were either those most expressive economically within their groups or those with a good perspective for diffusion in the Homogeneous Micro-Region 311-Vinicul tora de Caxias do SuI (MRH-311).

The description of the phenological phases proposed by AZZI (1959) was taken as a basis for determining the standard 
phenology for 11 cultivars of grapevine, 10 being of European origin (Vitis vinifera L.) and 1 American (Vitis labrusca L.). Budding occurred earlier for cultivars Isabel and Semillon, later for cv. white Moscatel and intermediately for cvs. Cabernet franc, Bonarda, italic Riesling, Merlot, Barbera, Trebbiano; Petit Syrah and Malvasia from Lipari. The sequence in the dates at which flowering took place showed a similar behavior to that for budding. Regarding the mean maturation date, cvs. italic Riesling, Semilion, Trebbiano, Isabel and Bonarda showed to belong to the 3 rd group on the Pulliat scale, while the remaining cvs. showed to belong to the 4 th group.

The thermal and heliothermal requirements of the various cultivars until reaching maturation were determined by summation of degree-days, active temperature and heliothermal product; for the extreme cultivars, $1299 \mathrm{DD}, 3087^{\circ} \mathrm{C}$ and 2.59 were needed, as an average, for cv. italic Riesling, and $1427 \mathrm{DD}, 3411^{\circ} \mathrm{C}$ and 3.17 for $\mathrm{cv}$. Cabernet franc. These values showed that the region under study presented thermal and heliothermal conditions within the required limits for other traditional viticultural regions. For the calculation of these indices, a base temperature of $12^{\circ} \mathrm{C}$ was considered for the entire cycle.

The possibilities for occurrence of diseases caused by fungi during the vegetative phase of grapevines were estimated through the hydrothermal coefficient proposed by ZULUAGA et alii (1971). The bioclimatic index of ConstanTINESCU (1967) was used to 
relate temperature and 1 ight availability to water availability. These indices showed that the region presented excessive humidity throughout the years, as the calculated values exceeded the established $1 \underline{i}$ mits for other viticultural regions.

The heliopluviometric maturation coefficient proposed by WESTPHALEN (1977) for evaluating conditions for grape maturation since color change to harvest showed that, though the humidity can be considered excessive, in some of the years adequate conditions exis ted for obtention of good quality grapes for vinification. 


\section{INTRODUÇAO}

A videira é cultivada em quase todas as partes do mun do, salvo em locais onde as condições térmicas e hídricas não oferecem um mínimo para o seu desenvolvimento.

No Brasil seu cultivo iniciou-se por São Paulo e se desenvolveu muito no Rio Grande do Su1. Esse desenvolvimento teve seu apogeu com a vinda de imigrantes italianos que foram assentados na En costa Superior da Serra'do Nordeste do Estado, que engloba a hoje deno minada Microrregião Homogênea 311 (MRH 311) - Vinicultora de Caxias do Sul.

Fazem parte da MRH 311 os municípios de Antonio Prado, Bento Gonçalves, Carlos Barbosa, Caxias do Sul, Farroupilha, Flores da Cunha, Garibaldi, São Marcos e Veranópolis. 
Segundo FERVI (1978) a indūstria vinícola, em 1977, representou em torno de $21 \%$ do faturamento industrial da MRH 311 e ab sorveu cerca de $11 \%$ dos empregos.

Do total de cerca de 333 milhões de quilos de uvas industrializadas no Rio Grande do Sul, em 1977, a indústria instalada na MRH 311 sorveu em torno de 328 milhões de quilos, sendo que $82 \%$ des ta uva constituia-se de cultivares americanas e híbridas e $18 \%$ prove nientes de cultivares européias (RIO GRANDE DO SUL, 1977). Para esse mesmo ano, segundo a UVIBRA (1977) a MRH 311 foi responsävel pela pro dução de 252 milhões de litros de vinho e derivados, que representavam cerca de $97 \%$ da produção vinícola comercializāvel do Estado.

Atualmente se define a aptidão climätica de uma certa região para o cultivo da videira atravēs de índices bioclimáticos. Os Indices que definem o ambiente mais adequado para o cultivo da videira estão bem caracterizados para regiões vitícolas tradicionais, tais como França, Espanha, Itālia, entre outras, nas quais encontram-se cul tivares bem adaptadas e cuja exploração vem se processando a centenas de anos. Por esse motivo, os índices elaborados a partir de parâmetros obtidos nessas regiões exprimem, com propriedade, as condições para o bom desenvolvimento da videira. A utilização desses índices em outras regiões que não aquelas para as quais foram estabelecidos, podem, mui tas vezes, apresentar resultados que não correspondem às expectativas. Por esse motivo, estudos que envolvam estabelecer o comportamento da cultura frente as condições do ambiente, em especial o clima, são ne- 
cessários no planejamento do seu cultivo, principalmente em regiões on de ele ainda não se encontra definitivamente ajustado.

o Programa Nacional de Pesquisas de Vitivinicultura (EMBRAPA, 1981) tem, entre suas prioridades, a delimitação de āreas mais aptas para o desenvolvimento da viticultura, através de estudos edafoclimáticos e de avaliações sobre o comportamento da videira. Embo ra a MRH 311 tenha sido considerada inapta para a viticultura européia no zoneamento agroclimätico do Rio Grande do Sul, os resultados quali-quantitativos da vitivinicultura nessas novas āreas certamente serão confrontados com aqueles obtidos na MRH 311. Por isso, é de grande interesse que os dados fenológicos, as necessidades térmicas e outros Indices bioclimāticos para a viticultura naquela microrregião sejam bem caracterizados.

Com base nisso, este trabalho tem como objetivos:

- caracterizar o padrão fenológico médio das principais cultivares de Vitis vinifera L., para a região de Bento Gonçalves;

- quantificar as necessidades térmicas e heliotērmicas para os diversos subperíodos de desenvolvimento dessas cultivares;

- caracterizar as potencialidades vitícolas através dos indices hidrotérmicos e heliohidrotérmicos. 


\section{REVISAO DE LITERATURA}

\subsection{Clima e distribuição da videira}

o meio vitícola é um conjunto de fatores que determi nam o potencial vegetativo individual. Os fatores naturais desse meio são o clima, o solo e a exposição topogrä́fica, sobre os quais o homem tem pouca ação; entretanto ele poderá escolher entres os outros fatores (espaçamento, porta-enxerto, sistema de condução, entre outros) os que melhor the aprouver. HUGLIN (1971) e GALET (1983) admitem que as técnicas agrícolas, tais como adubação, irrigação e práticas culturais não exercem muita ação sobre o meio natural.

GOBBATO (1940) considera o regime de chuvas, a temperatura do ar e a insolação como os elementos mais importantes para a videira. Ele comparou a região vinícola tradicional do Rio Grande do 
Sul com outras regiões do Estado, para a produção dé uva de mesa destị nada ao abastecimento dos grandes centros consumidores e concluiu que a região não seria a mais indicada. Esse é o motivo pelo qual a quase totalidade da produção é transformada em vinho.

SANTOS (1966) elaborou o fitoclimograma esquemático pa ra a videira no Brasil, utilizando-se do regime de temperaturas, chuvas, geadas e umidade do ar dos locais em estudo. Comparou esses valo res com as condições dos locais do globo onde a videira se desenvolve adequadamente. As condições mais próximas do ótimo seriam as que apresentassem temperaturas no inverno de 7 a $9^{\circ} \mathrm{C}$, de curta duração, com geadas para um melhor descanso, insolação intensa, umidade relativa mé dia do ar de 62 a $68 \%$ e regime de chuvas entre 630 e $785 \mathrm{~mm}$ anuais. Assim, delimitou zonas de condições que se aproximam do ótimo, zonas intermediārias de possível utilização e zonas sem condições de cultivo. As que se aproximam do ótimo apresentam condições favoráveis de temperatura, embora sejam caracterizadas por chuvas abundantes e/ou al to coeficiente de umidade. As intermediärias apresentam excesso de tem peratura na primavera, chuvas excessivas no verão e/ou umidade excessi va. As zonas sem condição de cultivo apresentam excesso de temperatura no inverno e na primavera.

VEGA (1969) comenta que a videira cresce melhor em re giões de verões longos e secos, moderadamente quentes, e com invernos relativamente frios para satisfazer às necessidades de repouso vegetativo. 
STAEHELIN et alii (1970), para as condições suiças, comentam que um bom clima para a viticultura se caracteriza por uma temperatura média superior a $18^{\circ} \mathrm{C}$, no verão e de $9^{\circ} \mathrm{C}$ durante o ano, por uma altura pluviométrica entre 580 e 1200mm, aliado a uma insolação í gual ou superior a 1800 horas.

Segundo ALMEIDA (1972), verões longos, quentes e secos, com precipitações menores que $20 \mathrm{~mm}$ mensais beneficiam a qualida de e a quantidade.

REDONDO (1973, 1974 e 1977) estabeleceu categorias de safras de uvas obtidas em Rioja Alta, norte da Espanha, baseado na qua lificação da colheita, mediante a marcha do ano meteorológico, fazendo comparações com as normais climāticas da região. Desse modo, é possível avaliar se a variāvel climática influiu positiva ou negativamente sobre a qualidade das uvas.

CARBONNEAU (1982) comenta que o clima da videira no Rio Grande do Sul è tropical úmido, com latitudes próximas a $30^{\circ} \mathrm{S}$, ocorrendo modificações importantes devido a altitude e a proximidade do oceano. A presença de temperaturas bastante altas, embora não excessivas, de uma insolação suficiente, e de uma pluviosidade abundante e re gular, conduzem a videira a externar ao meio seu vigor e a produzir a bundantemente, mas com limitação de ordem cultural. o excesso de chuvas e a elevada umidade relativa do ar influenciam negativamente no teor de açücar e contribuem para o aumento da incidência de moléstias, impedindo a maturação mais uniforme dos frutos. RIZZON e TONIET To (1982) comentam que nessas condições os mostos são pouco equilibrados, com baixos teores de açūcares e acidez elevada. 
GALET (1983) discutiu as possibilidades da videira se desenvolver nos vários climas existentes no planeta. Afirma que os climas do tipo mediterrânico, localizados entre os paralelos 30 a $39^{\circ} \mathrm{N}$ e 30 a $44^{\circ} \mathrm{S}$, apresentam as melhores condições para o desenvolvimento da videira, motivo pelo qual a maioria dos vinhedos mundiais são encontrados entre esses limites.

0 zoneamento da videira para o Rio Grande do Sul consi derou como região preferencial a que apresentou mais de 500 horas de frio (abaixo de $7^{\circ} \mathrm{C}$ ), uma soma de calor efetivo menor que $2300 \mathrm{GD}$ e um indice hidrotérmico menor que 50 (RIO GRANDE DO SUL, 1975). O de Santa Cata rina considerou como região preferencial a que apresentou mais de 400 horas de frio, uma soma de calor efetivo maior que $1900 \mathrm{GD}$ e menor que $2300 \mathrm{GD}$ e um Indice hidrotérmico maior que 80 e menor que 100(EMPASC,1978).

WESTPHALEN (1980) analisou os zoneamentos para a videira no Rio Grande do Sul e em Santa Catarina, colocando em evidência as diferenças de critérios utilizados para a avaliação das potencialida des vitícolas desses dois Estados. Quanto ao Rio Grande do Sul, comenta o rigorismo nos critérios adotados, os quais delimitaram as videiras européias a pequenas áreas do sudeste do Estado e classificaram como inaptas a região de maior produção do Brasil, ou seja, a MRH 311 . Es se autor considera os critérios adotados para Santa Catarina mais lógicos, pois, aplicados ao Rio Grande do Sul, não limitariam o cultivo na região tradicional da viticultura. Salienta, tambēm, que o de Santa Catarina não usou a expressão inapta, mas sim cultivo não recomendado, a qual evita o caräter estätico dado a muitos zoneamentos. 


\subsection{Fenologia da videira}

\subsubsection{Ciclo vegetativo}

De FINA e RAVELo (1973) definem a fenologia como o ra mo da ecologia que estuda os fenômenos periódicos dos seres vivos e suas relações com as condições do ambiente. Para esses autores fase ve getativa é o aparecimento, transformação ou desaparecimento dos órgãos das plantas. Duas fases sucessivas delimitam um subperíodo.

BERLATO et alii (1974) afirmam que o ciclo das plantas cultivadas é medido, muitas vezes, pelo número de dias que vai do início da brotação à maturação, enquanto o ciclo relativo das diversas cultivares è determinado pela comparação com cultivares tomadas como padrão e cuja fenologia média jā tenha sido determinada para o local.

A videira apresenta uma sucessão de ciclos vegetati vos, alternados por períodos de repouso. As variações climáticas que não permitem essa alternância, limitam o seu cultivo. Durante um ciclo vegetativo a planta sofre contínuas variações ou modificações de volu me, peso, forma e estrutura, de maneira que suas exigências e suscetibi lidade aos fatores do meio tambēm variam (HIDALGO, 1956).

o ciclo da videira é subdivivido em períodos: o que $\underline{1}$ nicia na brotação e vai até o fim do crescimento, também chamado perío do de crescimento; o que inicia na floração e vai até a maturação, cha mado período reprodutivo; o da paralisação do crescimento à maturação dos ramos, chamado período de amadurecimento dos tecidos; o que engloba desde o "choro" à desfolhação, chamado período vegetativo. Entre 
dois ciclos vegetativos existe um período de repouso. Esses períodos vão se sucedendo, paulatinamente, existindo uma interdependência entre si, sendo que o desenrolar de um depende daquele que o precede (GALET, 1983).

AZZI (1959) subdivide as fases naturais da vegetação da videira considerando os seguintes subperíodos: primeiro, desde o fim da colheita até o início da brotação; segundo, do início da brota ção até o início da floração; terceiro, do início da floração até a frutificação; quarto, da frutificação até a mudança de cor; quinto, da mu dança de cor à maturação compieta; sexto, do início a fim da vindima. GOBBATO (1940) comenta que a época em que as parreiras cumprem seus principais estádios vegetativos variam consideravelmente, mas, de um modo geral, para Caxias do Sul, a brotação ocorre do 19. decêndio de setembro ao 29 decêndio de outubro; a floração do 39 decêndio de outubro ao 29 decêndio de novembro; a maturação das uvas do 19 decêndio de janeiro ao 19 decêndio de abril e a desfol hação do 30 decêndio de maio ao 39 decêndio de junho.

Para a região sul do Brasil, SouzA (1969) comenta que a brotação ocorre entre 15 de agosto e 15 de outubro, o florescimento entre 15 de outubro e 15 de novembro a maturação dos frutos entre 19 de dezembro e 10 de abril e a queda das folhas entre 15 de maio 30 de julho.

CARBONNEAU (1982) comparou o comportamento da culti var Cabernet franc cultivada em Bento Gonçalves, RS, com a cultivada 
em Bordeaux, França. Constatou que Bento Gonçalves àpresenta o início da brotação quatro semanas mais precoce, em razão da temperatura mais elevada. 0 início da floração é, em média, seis semanas mais precoce. A mudança de cor é quatro semanas mais precoce; a maior necessidade no somatório das temperaturas ativas $\overrightarrow{\mathrm{e}}$ devida ao excesso de chuvas e $\bar{a}$ au sência frequente do efeito da seca estival que ocorre em Bordeaux. A maturação é atingida pouco antes, com uma necessidade de temperaturas ativas bastante superiores às exigidas em Bordeaux.

DIAS et alii (1982) relacionaram as fases fenológicas da cultivar Semillon em comparação com a 'Cabernet franc' separando a MRH 311 em dois pólos, segundo suas isoipsas. Para Bento Gonçalves a 'Semillon'inicia a brotação nos ūltimos dias de agosto e matura no 2 ? decêndio de fevereiro, enquanto a 'Cabernet franc'inicia a brotação no 20 decêndio do mês de setembro e matura no 10 decêndio do mês de mar ço. Para Caxias do Sul a cultivar Semillon inicia a brotação nos pri meiros dias de setembro e estā apta a ser colhida no 30 decêndio de fe vereiro, enquanto a'Cabernet franc' inicia a brotação no 20 decêndio de setembro e è colhida no 29 decên dio do mês de março.

\subsubsection{Repouso hibernal}

Ao final do outono, a multiplicação celular cessa e as folhas caem, pois a temperatura do ar e a do solo são insuficientes para permitirem o crescimento da videira. 
CHANDLER (1954) definiu o termo descanso como uma con dição de inibição de crescimento, isto é, não existe crescimento visí vel, embora ocorram atividades. O crescimento é retomado após a planta ser submetida a um período de baixas temperaturas.

SAMISH (1954) considera dois períodos, sendo o primei ro chamado de descanso e produzido por fatores externos, tais como tem peratura, fotoperíodo e práticas culturais; o segundo, denominado dor mência, é devido às condições internas da planta, relacionadas a enzi mas, a auxinas, e ao balanço promotor/inibidor.

Os invernos cujo frio $\vec{e}$ insuficiente para satisfazer às exigências, determinam anomalias fenológicas que redundam na redução dos rendimentos e da longevidade das plantas (LEDESMA, 1950; MOTA, 1957).

WINKLER (1965) comenta que o período de repouso é ne cessārio para a formação de hormōnios de frutificação, os quais trans formam as gemas vegetativas em gemas frutiferas.

PAI ANISWAMY et alii (1965) comentam as possibilidades de duas colheitas para os Estados de Madras e Mysore, sul da India, face às condições térmicas excessivas que não permitem que a videira entre em repouso pelo frio. VEGA (1969) comenta que, quando a temperatu ra mínima do ar for superior a $24^{\circ} \mathrm{C}$, o repouso vegetativo poderá ser conseguido pela suspensão da àgua de irrigação.

SoUZA (1969), comentando a viticultura da região do vale médio do São Francisco, diz que um longo período de seca, tanto 
do solo como do ar, faz com que a videira atinja o ponto de murcha, en trando em dormência.

Plantas que foram submetidas a periodos de altas temperaturas, no final do verão ou princípio do outono, requerem mais ho ras de frio para seu crescimento normal do que quando não foram expos tas a temperaturas altas (TABUENCA, 1965).

WESTPHALEN (1977) afirma que o Rio Grande do Sul, com preendido entre as latitudes 27 e $34^{\circ} \mathrm{S}$ e com altitudes de zero a pouco mais de 1000 metros, permite, com certas reservas, o repouso hibernal. A MRH 311, segundo EMBRAPA (1982), normalmente não apresenta problemas relacionados à quebra de dormenncia das gemas; entretanto, quando o in verno for ameno, resulta considerāvel nümero de gemas que não brotam.

As fases por que passam as gemas, depois de sua forma ção nos ramos até o início da brotação no ano seguinte, constituem e tapas que marcam seu estado fisiológico em função das condições do meio ambiente. POUGET (1972) avaliou os potenciais de crescimento das gemas, de acordo com a variação de sua velocidade para iniciar a brotação, em função da temperatura, subdividindo o ciclo anual das gemas em cinco fases sucessivas, desde sua formação até o início da brotação.

\subsubsection{Fase de pré-dormēncia}

Segundo POUGET (1972) esta fase è iniciada quando as gemas formadas sobre os ramos do ano atingem um nível de evolução sufi ciente para se tornarem aptas a se desenvolverem, se colocadas en con 
dições favoráveis; mas se continuarem nos ramos, ficam inibidas devido à dominância dos āpices vegetativos. Nessa fase, as potencialidades de crescimento são máximas. Essa fase é tanto mais longa quanto mais pre coce for a cultivar para iniciar a brotação. As cultivares de brotação tardia podem ter essa fase suprimida, pois são inaptas para iniciar a brotação durante certo período.

ZULUAGA et alii (1971) e WESTPHALEN (1977) comentam que as chuvas ao final do verão provocam ataques de fungos, os quais causam a desfolhação prematura e, como consequência, a ruptura dessa fase. Teremos como resultado uma brotação outonal, jā que não ocorre a fase de entrada em dormência.

\subsubsection{Fase de entrada em dormência}

POUGET (1972) diz que nessa fase a velocidade para o início da brotação atinge o mínimo. Cultivares de brotação tardia entram primeiro em dormência, enquanto as precoces apresentam um decrés cimo mais atenuado, entrando, por isso, mais tarde em dormencia.

A influência do fotoperíodo foi constatada por Alle weldt (1960) citado por GALET (1983), o qual afirma que o encurtamento do dia acelera esse fenômeno fisiológico.

A entrada em dormência coincide com a mudança de colo ração dos ramos e amadurecimento dos meritalos, uma vez que os ramos paralisam seu crescimento (POUGET, 1972). Vê-se que o estabelecimento da dormência coincide com a senescéncia dos äpices vegetativos e pontos de crescimento. 


\subsubsection{Fase de dormēncia}

POUGET (1966) diz que as cepas precoces tem dormência menos intensa que as tardias, pois exigem um tratamento mais curto de quebra da dormência e possivelmente apresentam uma velocidade de evo lução fisiológica mais rápida. Comenta, também, que cepas precoces apresentam uma constante de precocidade superior às tardias.

De um modo geral, os órgãos mais velhos, de crescimen to lento, favorecem a instalação da dormência. Os de crescimento rápido inibem seu estabelecimento (GALET, 1983).

\subsubsection{Fase da quebra de dormência}

POUGET (1972) comenta que, quanto mais tardia for a cul tivar para iniciar a brotação, maior será sua exigência em baixas tempe raturas. 0 período de frio deve ser contínuo para que as gemas alcancem um limiar de irreversibilidade em sua evolução fisiológica. Se es sa não for satisfeita, a quebra da dormência será inibida e ocorrerā u ma paralisação na evolução das gemas e um retorno ao estádio fisiológi co anterior, perdendo, assim, parte ou a totalidade das potencialidades de crescimento (BRANAS et alii, 1946; POUGET, 1972).

ZULUAGA et alii (1970) constataram que, se a quebra de dormência não ocorre nos meses de abril, maio ou primeiros dias de junho, a fase de pós-dormência interfere na brotação, resultando uma bro tação irregular e com alta percentagem de gemas inibidas. Isso ocorre em zonas quentes que apresentam um periodo de repouso curto e inadequa do. 
WESTPHALEN (1977) afirma que as regiões mais frias ou de maior altitude do Rio Grande do Sul têm mais possibilidades de satisfazer as exigências em frio. Ele propôs um índice de repouso hiber nal, representado pela temperatura média mensal do mês de maio que in dica, aproximadamente, as condições de cada localidade para satisfazer as exigências em frio, na fase da quebra de dormência. Considerou regiões preferenciais as que apresentam a temperatura média do mês de maio inferior a $14,5^{\circ} \mathrm{C}$ e regiōes inaptas quando maior que $16,6^{\circ} \mathrm{C}$.

POUGET (1972) comenta que as cultivares precoces podem ser consideradas como mais adaptadas a todos os climas, em compara ção com as tardias, por isso elas são encontradas em climas frios e também em climas de inverno acentuado, uma vez que a quebra de dormência è realizada com temperaturas mais elevadas que aquelas exigidas pe las cultivares tardias. Inversamente, as cultivares de brotação tardia possuem uma área de adaptação mais restrita, devido ao seu longo ciclo vegetativo e, sobretudo, devido à maturação de seus frutos ser quase sempre tardia.

\subsubsection{Fase de pös-dormência}

As gemas que foram submetidas a ação de baixas temperaturas, tornam-se aptas a iniciar a brotação mais rapidamente em qual quer temperatura, sendo esta adaptação mais intensa nas cultivares pre coces (POUGET, 1972).

Segundo ZULUAGA et alii (1970) ocorre um longo proces so fisiológico, durando em média 45 dias, onde os inibidores da brota- 
ção diminuem paulatinamente. Quando o período de vegetação ativa é maior que 280 dias, esta fase se sobrepõe com o período de brotação, o casionando brotação irregular, jā que a maioria das gemas se encontram inibidas.

\subsection{3. "Choro"}

Corresponde à entrada em atividade do sistema radicular, sob ação direta da temperatura do solo (BRANAS et alii, 1946). STOEV et alii (1971) consideram que a circulação da seiva inicia quando a temperatura do solo atinge $8^{\circ} \mathrm{C}$ na zona explorada pelas raízes, em bora varie segundo a espécie e cultivar. GALET (1983) comenta que o ex travazamento pode prolongar-se por três semanas, bem como ocorrer em alguns dias durante o período de início da brotação.

\subsubsection{Inĩcio da brotação}

STAEHELIN et alii (1970) afirmam que a brotação è pos sível graças às reservas acumuladas no lenho. Essas reservas são utili zadas até que os novos tecidos formados estejam aptos a sustentar o de senvolvimento da brotação.

Baggiolini (1952), citado por GALET (1983), descreve todo o processo de desenvolvimento de uma gema, da seguinte forma: no primeiro estádio, a gema principal estā em repouso, recoberta por duas escamas protetoras-ê o estädio de gema de inverno; no segundo estádio, próximo ao início do "choro", as gemas incham e as escamas se abrem, a 
parecendo a proteção fibrosa - é o estádio de gemas em algodão; no ter ceiro estádio, a gema continua a inchar e se alonga até iniciar-se o a parecimento do jovem broto- $\bar{e}$ o estädio de ponto verde.

As gemas de uma cepa não iniciam a brotação todas ao mesmo tempo para um determinado local. BRANAS et alii (1946), NEGROUL (1965a e 1965b), Ochoa (1965), citado por VEGA (1969) e COSTACURTA e ROSELLI (1980) afirmam que essas diferenças são devidas a uma proprieda de genética, mas dependentes das flutuações climāticas, exposição, na tureza do solo e práticas culturais.

Para COSTACURTA e ROSELLI (1980), quanto mais alta for a temperatura no período que precede a brotação, tanto mais precocemen te ela se realizará.

\subsubsection{Crescimento dos ramos}

A maioria das pesquisas adotam como expressão de cres cimento a elongação dos ramos e consideram a marcha do crescimento em função do tempo, expresso em dias, através de uma curva sigmóide (BRA NAS et alii, 1946). O crescimento $\bar{e}$ dependente dos materiais elaborados pelas folhas, das condições de nutrição e de umidade.

y Baggiolini (1952), citado por GALET (1983), comenta que os estädios que se seguem ao inỉcio da brotação são: quarto estádio, que corresponde ao aparecimento das folhas rudimentares, as quais permanecem presas, umas contra as outras (estādio de soltura das folhas); quinto estädio, no qual as folhas jovens estão expandidas e os ápices 
vegetativos perfeitamente livres; sexto estádio, no qual os cachos, em bora rudimentares, tornam-se visíveis, ocorrendo isso normalmente após o estabelecimento de três a cinco folhas.

\subsubsection{Florescimento}

Baggiolini (1952), citado por GALET (1983), descreve os estādios da floração da seguinte forma: sétimo estádio, no qual os ca chos se espaçam e se alongam sobre os ramos, enquanto os órgãos florais permanecem ainda aglomeraḍos; oitavo estádio, onde ocorre o apare cimento da forma típica da inflorescência, nas quais os botões florais estão nitidamente separados (estädio de botões florais separados); no no estädio, no qual começam a aparecer as flores.

A maioria das videiras apresentam flores alogamas e os insetos são elementos benéficos para a realização de uma boa floração.

\subsubsection{Maturação}

o perïodo de maturação inicia-se na mudança de cor das bagas e prossegue até a maturação.

TRIPOLI e MÜLLER (1981) estudaram o desenvolvimento dos frutos de 19 cultivares de videiras na região vitícola do Rio Gran de do Sul, analisando os parâmetros:comprimento, largura, peso fresco e peso seco das uvas, a fim de determinar o tipo de curva de crescimen to e época de maturação dos frutos. Encontraram curvas de crescimen 
to dos tipos sigmóides e duplo-signóides. Constataram, tạmbém, que o tamanho morfológico mäximo dos frutos nem sempre coincide com a matura ção fisiológica.

STOEV et a1ii (1971) afirmam que o início da maturação é caracterizado por profundas modificações, entre as quais apresentam destaque a parada do alongamento dos ramos, parada temporäria do aumento das bagas, diminuição da acidez e início do amadurecimento dos ramos.

CALÓ e COSTACURTA (1974), estudando as reações das cultivares aos fatores do meio ambiente, constataram que as cultivares de maturação tardia demonstraram ter um ritmo mais lento na brotação, mas, sobretudo, um alongamento do período que vai da floração à mudan ça de cor das bagas, quando comparadas às de maturação precoce. Atē o momento da floração os dois grupos de cultivares reagem da mesma forma. A qualidade de uma colheita depende, em grande parte, das reservas de nutrientes. Se estas forem abundantes, permitem que as uvas amadureçam mesmo que o ano seja desfavorāvel do ponto de vista climático, enquanto que, se as reservas forem pobres as uvas não recebem os nutrientes em quantidades suficientes, as folhas definham prema turamente e a consequência será uma colheita pobre em qualidade (GALET, 1983).

Pulliat (1879), citado por GALET (1983), foi o primei ro a estabelecer uma classificação das cepas em função da maturação das uvas, tendo como base a ëpoca de maturação da cultivar Chasselas doré. 
Essa classificação separa as cultivares em cinco grupos: primeiro gru po - precoces - maturam 15 dias antes da cv. Chasselas doré; segundo grupo - de primeiro amadurecimento - maturam junto com a cV. Chasselas doré; terceiro grupo - de segundo amadurecimento - maturam de 12 a 15 dias após a cv. Chasselas doré; quarto grupo - de terceiro amadurecimento - maturam de 12 a 15 dias após o terceiro grupo; quinto grupo - de quarto amadurecimento ou tardias - maturam de 15 ou mais dias apōs as do quarto grupo.

\subsubsection{Desfolhação}

Desfoliação é a queda natural das folhas no final do ciclo vegetativo. E um processo gradual, no qual é responsável o ácido abscísico. As folhas vão perdendo, progressivamente, a clorofila e ad quirem uma coloração amarelada. A respiração se reduz e a transpiração pára, em seguida as folhas se destacam e caem, sendo o fenōnemo acelerado pela ação do vento e da chuva (GALET, 1983).

\subsubsection{Amadurecimento dos tecidos}

Nos ramos, o amadurecimento dos tecidos inicia-se pela base e, progressivamente, vai atingindo a extremidade superior, po dendo paralisar-se a uma certa distância do äpice. o amadurecimento va ria segundo a temperatura, o vigor da cepa, a incidência de pragas e moléstias, isto é, dos fatores que não permitem um depósito de reservas adequado (BRANAS et alii, 1946; GALET, 1983). 
TABUENCA (1965) considera que as plantas com produções médias, resistem melhor ao frio em relação àquelas com elevada pro dução, pois possibilitam um maior acúmulo de reservas em seus tecidos. ZULUAGA et alii (1971) comentam que a atividade energética da planta está organizada, primeiro, para maturar seus frutos e após acumular reservas, processo que não se cumpre ou se cumpre imperfeitamente quando a maturação industrial dos frutos coincide com o amarelecimento das folhas.

GALET (1983) afirma que, se o ciclo vegetativo é indis pensāvel à vida da videira, o amadurecimento dos tecidos é necessārio à perenidade da cepa de um ano para o outro.

2.3. Elementos e fatores do clima e o desenvolvimento da videira 2.3.1. Luz

Para BUTTROSE (1974), quanto à luminosidade, deve ser considerada sua intensidade, duração e o dossel vegetativo. A videira, por ser uma planta heliófila, è exigente em 1uz. A falta de luz causa problemas, principalmente durante a floração e a maturação. NEMETH (1972) comenta que é fundamental, para a coloração das bagas e evolução do teor de açúcar, que a insolação durante o período vegetativo a tinja de 1200 a 1400 horas. HIDALGO e CANDELA (1971) consideram a viti cultura espanhola privilegiada, pois apresenta mais de 2000 horas. 
Azzi (1928), citado por HIDALGO (1956), diz que o en curtamento das horas do dia, no período brotação-floração, provoca um maior desenvolvimento dos ramos e folhas, uma antecipação do início da maturação e, como consequência, uma maturação mais perfeita.

BRANAS et alii (1946) consideram o amadurecimento dos tecidos dependentes da radiação solar e do arranjo da folhagem.

NITSCH (1957) constatou que, para a cultivar Concord, as temperaturas noturnas elevadas provocaram uma parada no crescimento, em condições de dias curtos. Afirma, ainda, que a interação do fotoperíodo com a temperatura contribui para modificar o ritmo vegetativo, so bretudo nas regiões mais quentes.

STAEHELIN et alii (1970) comentam a influência da luz nas formas dos órgãos vegetais. $\bar{A}$ sombra os caules são franzinos, as folhas pequenas e fracamente coloridas. A disposição da folhagem è muito importante para a fotossíntese e, consequentemente, para um bom acúmulo de reservas.

BUTTROSE (1974) comenta trabalhos realizados na cultivar Sultanina, por Shaulis e May (1971), onde foi obtido um aumento na fertilidade das gemas florais, através de uma descompactação do sis tema de condução em "latada".

Amerine e Singleton (1965), citados por ROSA FILHO (1973), estimaram que uma concentração de açücar da ordem de $24 \%$ corresponde a $4 \%$ formados pelas reservas da planta durante o erescimento e $20 \%$ sintetizados nas folhas, pela ação da luz solar, no periodo que vai do início ao fim da maturação das bagas. 
Segundo POUGET (1972), o fotoperíodo tem influência no ritmo vegetativo. Para esse autor as espécies e cultivares bastante precoces, originärias das regiões setentrionais da Europa e Âsia, são plantas de dias longos e sensíveis a um fotoperíodo curto. As cultivares tardias, originadas das regiões meridionais, parecem pouco sensiveis às variações do comprimento do dia.

REDONDO (1977) considera positivo quando o número de diàs encobertos, durante o período vegetativo, for inferior a $30 \%$ do total e que para uma boa colheita, o período que vai da mudança de cor à maturação deve ser bem ensolarado.

\subsubsection{Temperatura}

Todos os seres vivos apresentam limites de temperatura bem definidos. Qualquer excesso ou deficiência redundam em altera ções em seu metabolismo e,consequentemente, em seu desenvolvimento nor mal.

A fase da quebra de dormência é de curta duração, uma semana em média, e exige um período de frio com temperaturas médias diārias inferiores a $10^{\circ} \mathrm{C}$ (BRANAS et a11i, 1946; CONSTANTINESCU, 1967 ; WINKLER et alii, 1974).

Nigond (1967), citado por GALET (1983), lembra que a instalação e o nível de dormência não se manifestam igualmente para as gemas de um ramo, sendo as gemas da parte inferior do ramo mais dormen tes que as situadas na extremidade. Ele estima que a dormência desapa rece se a temperatura média do ar não diminuir abaixo dos $20^{\circ} \mathrm{C}$. 
ZULUAGA et alii (1971) comentam que temperaturas elevadas e fotoperíodo longo não permitem a instalação da dormência, pro vocando anormalidades na evolução da videira. Temperaturas médias míni mas diārias de $12^{\circ}$ a $18^{\circ} \mathrm{C}$ são necessärias para essa instalação.

CALÓ et alii (1971) constataram que a temperatura tem um papel determinante na abertura das gemas dormentes, sobressaindo-se dois efeitos. Um relativo ao início dos processos evolutivos que antecedem a brotação, com temperaturas superiores a $0^{\circ} \mathrm{C}$, mas que ficam blo queados abaixo desse valor. 0 outro, relativo à possibilidade efetiva das gemas se abrirem, com necessidades de temperaturas da ordem de pe 10 menos $10^{\circ} \mathrm{C}$ a $13^{\circ} \mathrm{C}$. Valores superiores, até atingirem $18^{\circ} \mathrm{C}$, incremen tam a velocidade, sendo que posteriormente vai ocorrendo um decrëscimo até se anular.

RIBAS (1962), comentando sobre as possibilidades da viticultura no médio São Francisco, diz que o excesso de calor durante todo o ano obriga a videira a vegetar constantemente. A ausencia do in verno modifica o ciclo natural da vegetação e ela entra em repouso pe la falta d'āgua.

A temperatura do ar tem estreita relação com a data do início da brotação (POUGET, 1966 e 1969). Esse autor diz que a velo cidade do início da brotação segue uma lei logarítmica da temperatura. KOKHANOVA (1972) observou uma correlação inversa entre a duração dessa fase e a temperatura. Nas cultivares destinadas à produção de uvas de mesa, altas temperaturas $\left(19,2^{\circ} \mathrm{C}\right)$ encurtaram a fase, enquanto baixas temperaturas $\left(15,6^{\circ} \mathrm{C}\right)$ a prolongaram. 
Para CALó e COSTACURTA (1974) existe uma correlação positiva entre a temperatura média do período imediatamente precedente à brotação e a antecipação na manifestação deste fenômeno. Observaram, também, que a brotação não está somente sob influências ambientais que se realizam no período que imediatamente a precede, porque o cálculo da correlação entre o seu aparecimento e a temperatura média do mês de jạ neiro coloca em evidência que um janeiro mais frio corresponde a uma brotação mais precoce. Isto confirma a ação do frio invernal sobre a futura evolução das gemas.

o florescimento està subordinado, essencialmente, à temperatura (GOBBATO, 1940; BRANAS et alii, 1946; STOEV et alii, 1971; CALO e COSTACURTA, 1974; CALÓ et alii, 1979; COSTACURTA e ROSELLI, 1980 e GALET, 1983). Este estádio é crítico ao desenvolvimento da planta, ao curso do qual as condições térmicas devem ser satisfeitas. Na ausência dessas condições especiais, o rendimento é afetado, embora o crescimen to possa se realizar de forma normal.

$$
\text { GOBBATO (1940) e STOEV et alii (1971) consideram .. a }
$$

temperatura ótima para o florescimento $15^{\circ} \mathrm{C}$, sendo regular e lenta en tre 18 e $20^{\circ} \mathrm{C}$ e räpida e menos regular entre os 20 e $25^{\circ} \mathrm{C}$.

CALÓ (1972) estudou a influência das condições do am biente sobre o desenvolvimento das bagas e constatou que a temperatura elevada durante a fase de floração acelerava o início de formação dos frutos, e que uma maior pluviosidade na fase floração - início de for ção dos frutos provocava um retardamento. 
BUTTROSE (1974), estudando a fertilidade das gemas, constatou que, entre os elementos climáticos, a temperatura e a lumino sidade foram os que apresentaram efeitos mais pronunciados.

GOBBATO (1940) afirma que os melhores vinhos são produzidos nas regiões que apresentam isotermas de $20-25^{\circ} \mathrm{C}$ durante o pe ríodo de maturação e que o conteúdo de açūcar nas bagas são diretamente determinados pelas temperaturas médias do período que vai da mu dança de cor à maturação.

Para VERDEREVSKIY (1962), se a temperatura média durante o mês mais quente do período de crescimento for de 17 a $19,5^{\circ} \mathrm{C}$, existem boas possibilidades de se conseguirem excelentes colheitas.

Para NEMETH (1972) a videira vegeta bem e produz a me lhor qualidade entre as isotermas de 9 a $16^{\circ} \mathrm{C}$, enquanto que entre $16 \mathrm{e}$ $21^{\circ} \mathrm{C}$ ela se desenvolve com exuberância, dando uma colheita abundante, mas de qualidade inferior. As regiões com isotermas entre 17 e $18^{\circ} \mathrm{C}$ são mais indicadas para a produção de vinhos tintos, enquanto as regiões com isotermas mais baixas seriam destinadas à produção de vinhos bran $\cos$.

A videira requer, durante o seu periodo vegetativo, temperaturas crescentes de 10 a $23^{\circ} \mathrm{C}$. Quando as temperaturas são infe riores a $10^{\circ} \mathrm{C}$ não ocorre crescimento, sendo que as superiores a $39^{\circ} \mathrm{C}$ prejudicam a videira (RIO GRANDE DO SUL, 1975).

Saunier (1960), citado por TABUENCA (1965), diz que os botões florais fechados resistem a $-1,1^{\circ} \mathrm{C}$; na plena floração, e fru 
tos jovens, $\mathrm{a}-0,5^{\circ} \mathrm{C}$, por um período de meia hora de exposição a essas baixas temperaturas.

BRANAS (1974) afirma que os órgãos amadurecidos são destruídos a $55^{\circ} \mathrm{C}$ durante 5 minutos e a $48^{\circ} \mathrm{C}$ durante três horas. Os ór gãos herbāceos sofrem desgastes quando a temperatura do ar atinge $-2,5^{\circ} \mathrm{C}$ ou quando u1trapassar os $42^{\circ} \mathrm{C}$ (SEGUIN, 1980).

\subsubsection{Regime hỉdrico}

As videiras são consideradas resistentes à seca, qua'iidade essa devida ao desenvolvimento considerável de seu sistema radi cular, capaz de penetrar no solo a grandes profundidades (HUGLIN, 1971; HIDALGO, 1980).

As chuvas de inverno não exercem influência direta sobre a videira e ficam armazenadas no solo. As de primavera condicionam taxa de crescimento, a elongação dos ramos e a superfície foliar, além de favorecer a incidência de moléstias (BRANAS et alii, 1946; GALET, 1983). Para Montpellier, França, GALET (1983) comenta que, quando as chuvas são inferiores a $200 \mathrm{~mm}$, os fungos praticamente não oferecem riscos. ZULUAGA et alii (1971) afirmam que, nas latitudes in feriores a $28^{\circ} \mathrm{S}$, frequentemente ocorrem chuvas no final do período ati vo de vegetação (dezembro-fevereiro), ocasionando intensos ataques tar dios dos fungos que provocam a desfolhação prematura e necrose dos bro tos. STOEV et a]ii (1971) afirmam que, para se obter uma produção de qualidade, $\vec{e}$ importante que ao longo da maturação a planta disponha de 
quantidades moderadas de àgua, sendo suficientes $100 \mathrm{~mm}$. As chuvas fre quentes são as causas do aparecimento das podridões das uvas.

As chuvas de verão, no Rio Grande do Su1, são de origem convectiva, com altas intensidades, as quais determinam uma menor qualidade e um favorecimento da ocorrência de doenças (WESTPHALEN, 1977). As chuvas de verão entre 80 a $150 \mathrm{~mm}$ são suficientes para não haver deficiências. As chuvas de outono, antes da colheita, podem au mentar a produção em plantas sadias. Caso as cepas jä estejam debilita das, os danos causados pelas chuvas serão mais intensos.

Azzi (1928), citado por GOBBATO (1940), considera co mo limite superior para as regiões vitícolas italianas os seguintes to tais de chuva: $94 \mathrm{~mm}$ no período de brotação até o início da floração; $25 \mathrm{~mm}$ da floração à fecundação; $135 \mathrm{~mm}$ da fecundação até o início do amadurecimento; $130 \mathrm{~mm}$ do começo do amadurecimento até o início da co Theita e $40 \mathrm{~mm}$ do início ao fim da colheita.

ALMEIDA e GRÁCIO (1969) comentam que, para a umidade do solo prōxima ao ponto de murcha permanente, nem a vegetação nem a pro dução sofrem sērios danos. Das necessidades hídricas totais para com pletar o ciclo, ela necessita cerca de $1 \%$ para iniciar a brotação, 1, $5 \%$ até a floração, $10 \%$ da floração à fecundação, $43 \%$ da fecundação à mudança de cor e $45 \%$ da mudança de cor à maturação.

Com relação à dispersão da videira, HIDALGO (1956) diz que ela é cultivada com êxito tanto em zonas em que as alturas pluviomëtricas não passam de $200 \mathrm{~mm}$, atẻ naquelas extremamente ümidas, com mais de $1000 \mathrm{~mm}$ anuais. 
Com respeito às duas colheitas anuais para Montes Cla ros, MG, AZZI (1959) salienta que, quando a maturação ocorre em agosto, apesar da menor disponibilidade térmica, a colheita propicía mostos de melhor qualidade em comparação com a colheita de fevereiro, e isso se deve à escassez de chuva para a colheita de agosto.

NEMETH (1972) considera como favorävel à viticultura a umidade relativa por volta de 70\%. Para RIO GRANDE DO SUL (1975), quan do a umidade atmosférica ultrapassar $80 \%$, ocorre um maior desenvolvi mento dos ramos e, consequentemente, maiores possibilidades para o ata que de fungos.

Quanto às necessidades de āgua, ALMEIDA e GRĀCIO (1969) afirmam que cada planta de videira necessita, em média, quatro litros de água por dia e em torno de 500 1itros por quilo de material lenhoso formado. Segundo GALET (1983), de 250 a 700 1itros de água são necessārios para produzir um quilo de matéria seca.

2.3.4. Orvaitho

0 orvalho atua, principalmente, no desenvolvimento do míldio (Plasmópora viticola Ber1. e Toni) o que explica certas contami nações em regiões de pouca precipitação. BRAVO e OLIVEIRA (1974) afir mam que o aparecimento do miَldio durante a época da floração impede que a fecundação ocorra normalmente, causando uma diminuição na produção. 


\subsubsection{Vento}

Os ventos fortes no início da vegetação podem causar grandes estragos, pois os ramos jovens destacam-se das cepas com relativa facilidade, diminuindo a produção e dificultando a poda do ano se guinte (DIAS et alii, 1982; GALET, 1983). SIMON e KOBLET (1978) estuda ram a influência da situação geogräfica e das variações climáticas so bre os vinhedos suiços. Constataram que vinhedos com exposição leste beneficiavam-se, no outono, de um periodo de ventos quentes, os quais aceleravam a maturação das uvas.

\subsubsection{Fatores geogrāficos}

Os elementos meteorológicos dependem das condições geográficas do local da observação. Entre os fatores geográficos desta cam-se a latitude, a altitude, o relevo, a exposição do terreno, as florestas e a proximidade de massas d'água entre outros (BRANAS, 1974; GALET, 1983).

\subsubsection{Latitude}

TAMARO (1920) comenta que, para o hemisfério norte, o aumento de um grau de latitude, corresponde a um atraso de dois a seis dias no início da brotação e ocorre um prolongamento do ciclo vegetati vo.

Analisando os critérios ecológicos para a delimitação dos vinhedos setentrionais europeus, BECKER (1978) constatou que o $1 \underline{i}$ mite para o plantio seria aquele que proporcionasse uma suficiente so 
ma de temperaturas para atender a uma determinada qualidade bem como um período mínimo médio livre de geadas. Para o hemisfério norte o 1 i mite é o paralelo 50, enquanto para o hemisfério sul é o 40 (SEGUIN, 1980; GALET, 1983).

Para COSTACURTA e ROSELLI (1980) a ārea da viticultura mundial estä compreendida entre as latitudes de 20 a $50^{\circ} \mathrm{N}$ e 20 a $40^{\circ} \mathrm{S}$. A medida que se aproxima dos polos, ocorre um retardamento dos fenômenos vegetativos; aproximando-se dos trópicos, ocorre o processo inverso.

\subsubsection{Altitude}

WINKLER (1965) comenta que a videira se adapta desde altitudes inferiores ao nível do mar (61 metros abaixo, na California) até altitudes elevadas (2473 metros, na Bolívia). TAMARo (1920) diz que a cada acréscimo de cem metros de altitude corresponde um atraso do início da brotação de um ou dois dias e de um a quatro dias na floração e maturação.

NEMETH (1972) demonstrou que o teor de açücar das $\underline{u}$ vas pode baixar de 0,5 a $1^{\circ}$ para cada acréscimo de cem metros de altitude. BRAVO e OLIVEIRA (1974) afirmam que, à medida que aumenta a altí tude, a maturação das uvas se atrasa, a qualidade e a produção diminuem, pois a videira vegeta ma1. GALET (1983) afirma que a temperatura decresce, em média, $0,6^{\circ} \mathrm{C}$ a cada cem metros de altura, causando um atraso na vegetação de um dia para cada 30 metros de altura até os 1000 metros e, após, um dia cada 20 metros. 


\subsubsection{Relevo e exposição}

Os terrenos de colina são mais propícios à viticultura, pois o solo é menos fértil que nos vales e as colheitas menos abun dantes, proporcionando um produto mais equilibrado. Os nevoeiros se dissipam mais rapidamente, possibilitando uma maior insolação (BRAVo e OLIVEIRA, 1974; GALET, 1983). De uma maneira geral, toda a forma concava do terreno aumenta a amplitude de variação diurna da temperatura, enquanto a convexa tende a diminuir (SEGUIN, 1980).

\subsubsection{Florestas}

As florestas abrigam os vinhedos contra os ventos frios e diminuem a amplitude de variação diäria da temperatura, devido à massa de vapor d'água que elas cedem à atmosfera, a qual intercepta a radiação terrestre (BRANAS, 1974; GALET, 1983).

\subsubsection{Proximidades de massas d'água}

As massas d'ägua podem favorecer o desenvolvimento de vinhedos devido à diminuição da temperatura média do verão,bem como pos sibilitam uma maior temperatura média no inverno. Certos locais apre sentam um período de repouso hibernal mais curto e menos intenso por estarem próximos às massas d'água (BRANAS, 1974; GALET, 1983). 
2.4. Parâmetros de caracterização das exigências climäticas da videira

\subsubsection{Caracterização tērmica}

AZZI (1959) comenta que a influência da temperatura é de ação mais imediata e limitada que a da chuva, e isso é uma das cau sas determinantes da imprecisão dos equivalentes de calor. Durante os períodos críticos a videira não tolera excessos ou deficiências térmicas os quais não podem, como as chuvas, ser armazenados em períodos abundantes para posteriormente suprir as necessidades dos tempos adver sos.

CONSTANTINESCU (1967) diz que o balanço térmico tem como objetivo explicar a interdependência entre a videira e o potencial heliotérmico. Para ZULUAGA et alii (1971) o balanço térmico é uti lizado para classificar zonas ecológico-geogräficas e para relacioná-las às exigências térmicas dos subperíodos do ciclo vegetativo, espe cialmente para estudar a época de maturação.

VILLA NOVA et alii (1972) comentam que é provāvel que as unidades térmicas expressem a interação de alguns fatores que afetam a planta simultaneamente. Graficamente, unidades térmicas correspondem à ärea compreendida entre a curva da temperatura e a temperatu ra-base, considerando a curva da temperatura idêntica a uma senóide. Mediante a temperatura máxima, mínima e base,propuseram expressões pa ra estimar o valor dessa ärea e consequentemente, do número de grausdia. 
Não existe uma relação entre o somatório da temperatu ra e a qualidade da produção. PAGLIARI (1980) comenta que em um ano $\operatorname{com} 3219^{\circ} \mathrm{C}$ foi considerado excepcional quanto à qualidade, enquanto ou tro com $3210^{\circ} \mathrm{C}$ foi considerado ordinärio.

\subsubsection{Zero de vegetação (temperatura-base)}

Tambēm denominado de $\mathrm{TO}^{\circ}$ (BRANAS et alii, 1946), zero aparente de vegetação (Nigond, 1957, citado por ZULUAGA et alii, 1971), ou limiar de crescimento aparente (Pouget, 1968, citado por ZULUAGA et alii, 1971).

Para esses autores zero de vegetação é a temperatura abaixo da qual não ocorre desenvolvimento vegetativo. PRIMAULT (1969) considera como a temperatura na qual o movimento dos sucos celulares cessam. Não se trata da morte dos tecidos, mas sim de uma interrupção do crescimento. E variável segundo os anos e cultivares, mas para a vi deira tem sido utilizado $10^{\circ} \mathrm{C}$ como um valor médio (BRANAS et alii, 1946; CONSTANTINESCU, 1967; HIDALGO, 1980).

$$
\text { Nigond (1957), citado por GALET (1983), ZULUAGA et }
$$

alii (1970) e POUGET (1972) dizem que o zero de vegetação è a versão a gronômica do conceito fisiológico do limiar de crescimento aparente, pois o limiar de crescimento real inicia-se com temperaturas mais bai xas. As temperaturas de 0 a $5^{\circ} \mathrm{C}$, na fase de pré-brotação, não bloqueiam a multiplicação celular mas reduzem ao mínimo o número de mitoses, cau sando uma paralisação quase que total dos processos metabólicos. 
Esse Indice constitui a base para a determinação da temperatura média verdadeira, deixando düvida se as temperaturas infe riores a este valor são efetivas para o crescimento da videira (ZULUAGA et alii, 1970). TABUENCA (1965) considera que qualquer temperatura inferior ao limiar de vegetação produz o mesmo efeito.

BRANAS et alii (1946) comentam que a latitude influen cia o $\mathrm{TO}^{\circ}$; quanto maior a latitude, menor o $\mathrm{TO}^{\circ}$.

Com a finalidade de determinar a temperatura-base, AR NoLD (1959) utilizou o somatōrio das unidades térmicas de uma série de experimentos, a partir de diversos valores de temperatura-base escolhi dos previamente, considerando a temperatura-base aquela que forneceu o menor valor do desvio padrão, em dias.

POUGET (1967), observando a data do início de brotação de uma cultivar, constatou que a brotação se iniciava quando a so ma das ações diärias da temperatura média atingiam um valor caracterís tico para aquela cultivar. Estimou que a média aritmética da soma dos dez dias anteriores à brotação representariam o zero de vegetação.

ZULUAGA et alii (1971) comentam que em algumas regiões o $\mathrm{TO}^{\circ}$ pode representar um limite mínimo ou aproximado da temperatura-base para que a videira inicie seu crescimento. 


\subsubsection{Período ativo}

0 período ativo é definido como o período durante o qual a temperatura média do ar é igual ou superior ao zero de vegetação (BRANAS et alii, 1946; HIDALGO, 1980).

ZULUAGA et alii (1970) consideram-no sob dois aspectos: o fisiológico e o climático. O fisiológico abrange desde a brotạ ção ao amarelecimento das folhas. o climático corresponde ao período livre de geadas, com temperaturas médias superiores ao zero de vegeta ção.

CONSTANTINESCU (1971) e VLACHOS (1971) comentam que a sua duração, em relação a uma determinada cepa, varia não somente segundo a região, mas, tambëm, para a mesma região, pois sofrem influências, principalmente, da evolução das condições climáticas e outros fa tores culturais.

WESTPHALEN (1977) considerou que o período ativo para a viticultura gaúcha se extende de setembro a abril, embora; se fosse considerado o período com temperatura superior a $10^{\circ} \mathrm{C}$, deveria estar incluído todo o inverno.

\subsubsection{Temperatura ativa}

Denomina-se de temperatura ativa o somatório das temperaturas médias diārias superiores ao $\mathrm{TO}^{\circ}$ que ocorrem durante o perío do ativo de vegetação (BRANAS et alii, 1946). 
De FINA e RAVELO (1973) comentam que Reaumur foi o primeiro a considerar o somatório das temperaturas médias durante o de senvolvimento dos vegetais e que esse somatório era constante para um determinado subperíodo, independentemente dos extremos de temperatura. Reaumur considerava útil toda a temperatura média acima de zero grau. SAFRAN e HOCHBERG (1971) comentam que, quando a temperatura mêdia do ar durante o período ativo de vegetação for sempre su perior ao $\mathrm{TO}^{\circ}\left(10^{\circ} \mathrm{C}\right)$, não se justifica o cälculo das temperaturas ativas.

\subsubsection{Graus-dia}

Tembëm denominado de temperatura média verdadeira (BRA NAS et alii, 1946), temperatura ütil de crescimento (ZULUAGA et alii, 1971) e temperatura eficaz (Teodorescu, 1949, citado por ZULUAGA et alii, 1971). A temperatura eficaz $\vec{e}$ determinada pela diferença acumula da, durante o ciclo vegetativo, entre a temperatura média diäria e o TO ${ }^{\circ}$, excluindo os dias em que o $\mathrm{TO}^{\circ}$ for maior que a temperatura média. São as temperaturas responsáveis pelo desenvolvimento das plantas (BRA NAS et alii, 1946; GALET, 1983).

Winkler e Amerine (1962), citados por HIDALGO (1980), correlacionaram os principais parâmetros climáticos das äreas produtoras de vinhos com dados analíticos e com a qualidade do produto. Constataram que a temperatura foi o ünico fator do clima que demonstrou ter importância predominante. Partindo disso, estabeleceram um índice 
térmico que corresponde ao número de graus-dia, subtraindo das tempera turas médias mensais o $\mathrm{TO}^{\circ}\left(10^{\circ} \mathrm{C}\right)$ e multiplicando o resíduo pelo número de dias favoráveis à vegetação.

ALMEIDA (1972) considera que as zonas onde mais rapi damente se atingem maiores somas tërmicas devem ser indicadas para o cultivo de uvas de mesa.

VAN DEN BRINK (1974), estudando a época de maturação da cultivar Concord no sudeste de Michigan, EEUU, constatou que a matura ção ótima ocorria após 85 dias da data em que 1000 unidades de calor e ram acumuladas, ou 63 dias após 1500 unidades acumuladas. Dados de 13 anos apresentaram uma variação de 501 unidades entre a colheita mais tar dia (3038 GD) e a mais precoce (2537 GD). Em média, 2747 GD são requeridos para a maturação da uva Concord,e o início da colheita pode variar em mais de três semanas, de um ano a outro.

LINDSEY e NEWMAN (1956) comentam que o uso da tempera tura, sozinha, não significa que não se esteja adotando a influência de outros fatores influentes sobre a planta.

Muitos pesquisadores passaram a utilizar métodos ecológicos mais racionais, tanto para delimitar zonas como para a classificação de cultivares de videiras. A inclusão de outros elementos que poderiam limitar a produção e a qualidade das uvas, entre os quais, a insolação, precipitação e a umidade do ar, começam a fazer parte desses novos indices. 


\subsubsection{Caracterização heliotērmica}

Geslin (1944), citado por De FINA e RAVELO (1973), as sociou o desenvolvimento de um vegetal com o produto da temperatura mé dia diāria e da duração média do dia. Ao somatório desses valores, pa ra um determinado período, dividido por 100, denominou de índice helio térmico.

BRANAS et alii (1946) modificaram o indice de Geslin, a fim de definir a aptidão climática de uma região para o cultivo da vi deira e denominaram de produto heliotérmico. Ele representa o produto das somas das temperaturas eficazes pelas horas de luz, durante o período ativo de vegetação. Com isso, separaram as cultivares da 1 a a $4^{\text {a }}$. época de maturação com valores inferiores a 2,8 até superiores a 4,5. ZULUAGA et alii (1971) consideraram as províncias de Missiones e Corrientes, limitrofes com o Rio Grande do Sul, inaptas por apresentarem um indice superior a 9,0 , isto $\bar{e}$, condições pouco favoräveis ao repouso vegetativo. WESTPHALEN (1977) não encontrou elementos para confirmar tais considerações.

WESTPHALEN (1977) diz que a insolação máxima possível acumulada no período favorävel ao ciclo da videira, pouco varia para - Rio Grande do Su1, o que justifica a adoção de limites baseados na soma de temperaturas efetivas. Considerou, para as cultivares européias de melhor adaptação para o Rio Grande do Sul, que o valor do produto heliotérmico deveria ser maior que 5,0 e menor que 9,0 para 0 período da brotação ao amarelecimento das folhas. 
BRANAS et a1ii (1946) e ZULUAGA et alii (1971) comentam que as cultivares de maturação precoce podem ter as mesmas ou supe riores exigências heliotérmicas que as tardias, uma vez que as precoces são de baixo $\mathrm{TO}^{\circ} \mathrm{e}$ isso permite que aproveitem para o seu crescimento e desenvolvimento temperaturas ambiente mais baixas e, por isso, completem antes seu ciclo vegetativo.

As exigências heliotérmicas das cultivares variam, so bretudo, em função do vigor. Os genōtipos mais vigorosos são mais exigentes e sofrem mais facilmente em presença de deficiências térmicas, atrasando a maturação e produzindo bagas de menor qualidade (ZULUAGA et a1ii, 1971).

ZULUAGA et alii (1971), para avaliarem a evolução de um clone, ampliaram o ciclo vegetativo,que normalmente $\bar{e}$ considerado até a maturação industrial,e o consideraram atē o amarelecimento das folhas. Chamaram de indice heliotërmico de adaptação ao índice que re presenta o produto heliotérmico até o amarelecimento das folhas, descontado do produto heliotérmico atë a maturação industria1. Um baixo Indice se obtëm quando uma cultivar, cujo "habitat" tenha sido um cli ma quente, isto é, de longo período de vegetação, é translocada para climas temperados com curtos períodos ativos de vegetação. Neste caso - subperíodo da maturação industrial - amarelecimento das folhas se en curta ou desaparece, entrando o clone em um räpido processo de senilidade. 
Huglin (1978), citado por COSTACURTA e ROSELLI (1980), modificou o Indice de BRANAS et alii (1946), levando em consideração o produto do somatório da semi-soma entre a temperatura média e a temperatura máxima diāria e o comprimento do dia, durante o período vegetativo. Considerou que quando essse valor for inferinr a 1500, o cultivo da videira não é possível. Acima de 2400 as possibilidades heliotérmicas são ideais.

2.4.3. Caracterização hidrotérmica e o desenvolvimento de fungos

Baseados no fato de que o desenvolvimento do míldio depende da frequência das chuvas e das temperaturas médias, BRANAS et alii (1946) estabeleceram o indice hidrotérmico, que è resultante da soma dos produtos mensais da temperatura média, em ${ }^{\circ} \mathrm{C}$, pela quantidade de chuva, em mm, durante o período favorāvel à incidência do fungo. Con sideraram como limite inferior o valor 2500, isto é, quando o ataque do fungo não causaria problema, e como superior o valor 5100, além do qual é economicamente impossivel o cultivo da videira europëia, face a infestação dos fungos, mas podem-se cultivar videiras americanas e hibridas, uma vez que são mais resistentes às doenças füngicas.

Para as doze regiões vitícolas espanholas, HIDALGO (1980) encontrou valores entre 525 a 5375.

ZULUAGA et alii (1971) modificaram o indice hidrotérmico de BRANAS et alii (1946), tendo em vista que o periodo para o de senvolvimento do fungo $\bar{e}$ maior na Argentina do que na França. Chamaram 
de coeficiente hidrotérmico à relação existente entre o indice hidrotérmico e o número de dias do período favorável. Obtiveram valores que variaram de 30 a 40 . Quanto maior o valor, mais intenso serä o ataque de fungos. As condições epidemiológicas para a infecção e reprodução tornam-se favorecidas por uma alta umidade atmosfërica, neblina e orvalho.

WESTPHALEN (1977) considera a modificação proposta por ZULUAGA et alii (1971) mais apropriada para as condições do Rio Grande do Sul. O zoneamento para a videira européia no Rio Grande do Sul con sidera os limites para a região preferencial quando inferiores a 50 e inapta quando superiores a 70 .

Tanto o indice hidrotérmico de BRANAS et alii (1946) como o coeficiente hidrotérmico de ZULUAGA et alii (1971) são influenciados pela distribuição estacional das precipitações. Menores precip tações acumuladas em um ou dois meses podem ser mais prejudiciais, quan to ao aspecto fitossanitário, do que aqueles de maior precipitação, po rēm, distribuỉdas em um maior número de meses (WESTPHALEN, 1977).

\subsubsection{Caracterização heliohidrotērmica}

$$
\text { CONSTANTINESCU (1967) relacionou os coeficientes de }
$$

temperatura (temperatura ativa mẻdia diāria) e de insolação (insolação média diária) com o coeficiente de precipitação (precipitação média diāria) durante o período ativo de vegetação. Esse indice é de signifí cação biológica, pois relaciona as possibilidades diárias da fotossin- 
tese, (temperatura e luz) com as disponibilidades diärias de água. Ele pode ser utilizado como estimativa do défice e do excedente teórico de água do solo. Para a Romênia, encontrou valores que variaram de 3,0 (forte excedente) a 18,2 (défice acentuado), estimando tambëm, que o e quilỉbrio ótimo se produz quando o indice estiver entre $10 \pm 5$.

HIDALGO (1980) encontrou valores de 7,3 a 42,5 para a Espanha. Por isso, propôs uma modificação no indice de Constantinescu, principalmente quanto às disponibilidades diärias de ägua. Relacionou a temperatura eficaz e a iluminação eficaz com a precipitação anual, sem considerar o número de dias de duração do período vegetativo. Procedendo assim, encontrou valores de 3,9 a 103,4, afirmando que 0 equilỉbrio ótimo estā entre $15 \pm 10$.

WESTPHALEN (1977), para caracterizar as condições de maturação das uvas, dá mudança de cor à maturação comercial, estabele ceu um Indice ao qual denominou de quociente heliopluviométrico de ma turação. Este índice relaciona a insolação efetiva acumulada dos meses de dezembro a fevereiro, com a precipitação total desse periodo. 0 zo neamento para a videira americana no Rio Grande do Sul considera como região preferencial a que apresenta um indice maior que dois (2) e co mo região inapta quando o indice for menor que 1,5 . 
44.

3. MATERIAL E METODOS

3.1. Clima e Solo

3.1.1. Caracterização do clima da Microrregião Homogênea 311 Vinicultora de Caxias do Sul (MRH311).

o clima que compreende a MRH311, a qual possui altitu des superiores a $600 \mathrm{~m}$, foi classificado por MORENO (1961) como sendo temperado, de förmula $\mathrm{Cfb}$, segundo a classificação climática de Köppen. Este tipo climático apresenta a temperatura média do mês mais frio entre -3 e $18^{\circ} \mathrm{C}$, chuvas em todos os meses e a temperatura média do mês mais quente inferior a $22^{\circ} \mathrm{C}$. Durante a maior parte do ano sofre influên cias da massa tropical Atlântica é no inverno da massa polar Atlântica. As chuvas no verão são influenciadas pelos ventos alísios úmidos e as de inverno pelo deslocamento dos anticiclones. A nebulosidade varia de 43 a $50 \%$, sendo mais frequente de abril a agosto.

A tabela 1 fornece as normais climáticas para o Município de Bento Gonçalves e/ou para a MRH311. 


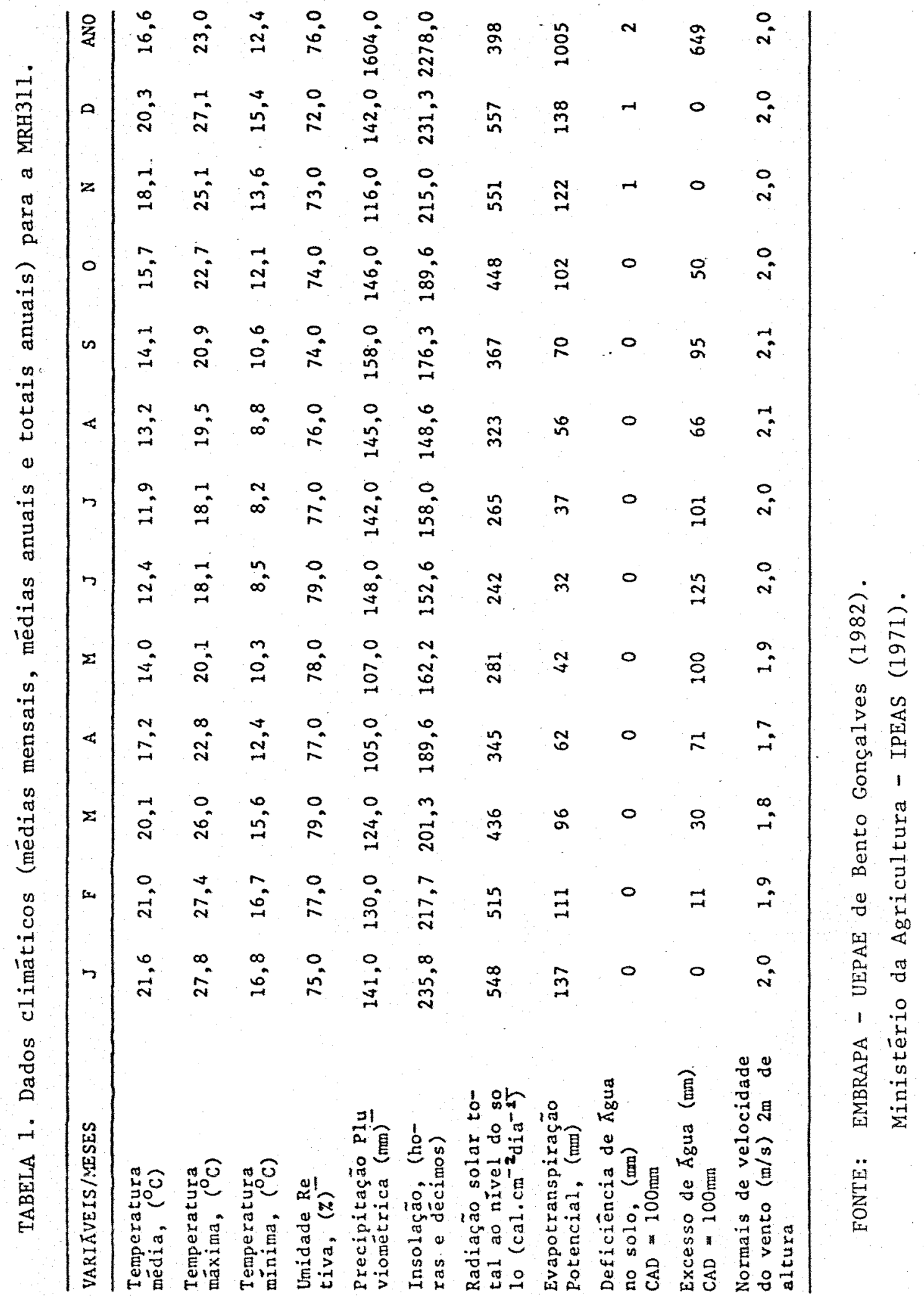




\subsubsection{Caracterização do solo da MRH311}

A região è caracterizada por um relevo acidentado, com solos rasos e pedregosos, predominando os solos pertencentes às asso ciações Ciriaco-Charrua e Caxias-Farroupilha-Carlos Barbosa. Os solos Ciriaco-Charrua apresentam altos teores de argila, são levemente äcidos, com saturação de base alta e teor de alumínio trocável praticamente nulo. Apresentam teores de matéria orgânica de médios a altos $(>1,5 \%)$, os de fósforo baixos $(<0,8 \mathrm{me})$ e os de potássio altos $(>0,40 \mathrm{me})$ (LEMOS et alii, 1967). Os solos Caxias-Farroupilha-Carlos Barbosa são argilosos, àcidos, com saturação de base de média a baixa e com alto teor de alumínio trocável. Apresentam teores de matéria orgânica médio $(1,5 \%)$ e baixo de fósforo $(<0,8 \mathrm{me})$ e potássio $(<0,12 \mathrm{me})$ (EMBRAPA, 1982$)$.

\subsection{Dados meteorológicos}

Os dados meteorolögicos foram coletados na Estação A grometeorológica da UEPAE de Bento Gonçalves, pertencente ao 89 Distri to de Meteorologia do Instituto Nacional de Meteorologia, situada a $29^{\circ} 15^{\prime}$ de latitude su1, $51^{\circ} 31^{\prime}$ de longitude oeste e a altitude de $671 \mathrm{~m}$. Para este trabalho utilizaram-se os dados do período de 1965 a 1978 .

As variáveis climáticas utilizadas foram:

- Temperatura mínima do ar, em ${ }^{\circ} \mathrm{C}$;

- Temperatura mäxima do ar, em ${ }^{\circ} \mathrm{C}$;

- Temperatura média do ar, em ${ }^{\circ} \mathrm{C}$, calculada através da expressão: 


$$
\mathrm{t}_{\mathrm{m}}=\frac{\mathrm{T}_{9}+2 \mathrm{~T}_{21}+\mathrm{T}_{\mathrm{M}}+\mathrm{T}_{\mathrm{m}}}{5}
$$

onde

$$
\begin{aligned}
& t_{m}=\text { temperatura média diäria; } \\
& T_{9}=\text { temperatura do termômetro de bulbo seco às } 9 \text { ho } \\
& \text { ras; } \\
& T_{2 I}=\text { temperatura do termômetro de buibo seco às } 21 \\
& \text { horas; } \\
& T_{M}=\text { temperatura do termômetro de mäxima; } \\
& T_{m}=\text { temperatura do termômetro de minnima. }
\end{aligned}
$$

- Insolação, obtida através de heliógrafo Campbel1-Stokes, em horas e décimos.

- Precipitação pluviométrica, através de pluviômetro tipo Vi1 le. de Paris, com superfície de captação de $400 \mathrm{~cm}^{2}$, em $\mathrm{mm}$.

- Duração do dia, calculados para a latitude de $29^{\circ} \mathrm{S}$ por VILLA NOVA e OMETTO (1978).

\subsection{Dados fenológicos}

Da coleção de cultivares da antiga Estação Experimental de Bento Gonçalves (MA/IPEAS) foram utilizadas onze cultivares de videiras, ou por serem as de maior expressão econômica dentro de seus grupos ou por apresentarem uma boa perspectiva à difusão, face às suas potencialidades agronômicas e enológicas. 
Cultivares brancas utilizadas:

Vitis vinifera L. cultivar Malvasia de Lipari

Vitis vinifera L. cultivar Moscatel branco

Vitis vinifera L. cultivar Riesling itālico

Vitis vinifera L. cultivar Semillon

Vitis vinifera L. cultivar Trebbiano

Cultivares tintas utilizadas:

Vitis vinifera L. cultivar Barbera

Vitis vinifera L. cultivar Bonarda

Vitis vinifera L. cultivar Cabernet franc

Vitis labrusca L. cultivar Isabel

Vitis vinifera L. cultivar Merlot

Vitis vinifera $L$. cultivar Petit Syrah

As avaliações fenológicas foram realizadas, para todas as cultivares, sobre um lote de, no minimo, 50 plantas, com mais de três anos de idade, localizadas nas imediações do posto agrometeoro 1ögico. Todas as plantas eram enxertadas sobre o porta-enxerto 101-14 (V. riparia $\times \underline{\text { V }}$ rupestris $101-14 \mathrm{Mgt.}$ ). O sistema de condução era a espaldeira com três fios de arame (o 19 a 0,80 , o 29 a 1,10 e o 39 a $1,50 \mathrm{~m}$ acima do solo). A poda, normalmente, foi efetuada em agosto no cordão permanente estendido sobre o 19 fio, sendo mista com varas de quatro a oito gemas $e$ esporões de duas gemas, resultando de 50 a $55 \mathrm{mil}$ gemas por hectare, para um espaçamen- 
to de $2,0 \times 1,5 \mathrm{~m}$. Outras práticas culturais, como adubações, manejo do solo, tratamentos fitossanitários, foram efetuados à medida das necessidades das plantas.

Dez das onze cultivares utilizadas (excetuando a cultivar Petit Syrah) estão incluídas na classificação botânica efetuada por BÂN (1979), para Caxias do Sul e Bento Gonçalves.

A descrição dos estádios fenológicos proposta por AZ ZI (1959) foi tomada como base para determinar os diferentes subperiodos estudados, considerando-se os estädios descritos em 3.4.

\subsection{Determinaçöes fenolögicas}

3.4.1. Inỉcio ao final da brotação (IB-FB)

A data do início da brotação foi considerada quando $50 \%$ das gemas atingiram o 39 estádio da descrição proposta por Baggiolini (1952), citado por GALET (1983), estádio de ponto verde, ou seja, começando a aparecer o jovem broto sobre as gemas (BRANAS et alii, 1946; AZZI, 1959; ZULUAGA et alii, 1971; GALET, 1983). O fina1 da brotação foi considerado quando cessava a abertura das gemas, embora ainda pudessem permanecer gemas dormentes sobre os ramos.

3.4.2. Inïcio ao final da floração (IF-FF)

A data do início da floração foi considerada quando $50 \%$ das flores se abriram, ou seja, atingiram o 9 estādio da descrição 
proposta por Baggiolini (1952), citado por GALET (1983), e o final da floração quando ocorreu o término da queda das caliptras (BRANAS et alii, 1946; AZZI, 1959; ZULUAGA et alii, 1971; GALET, 1983).

\subsubsection{Inĩcio ao final da maturaçăo (IM-FM)}

A data do início da maturação foi considerada quando $50 \%$ das bagas mudaram de coloração, isto é, as bagas das cultivares de película branca se tornaram translücidas e as bagas das cultivares tin tas adquiriram uma coloração avermelhada. A data do final da maturação foi considerada a data da colheita da uva que, normalmente, ocorre quan do as bagas apresentam os máximos teores de açūcares.

\subsubsection{Inicio ao final da queda das folhas (IQF-FQF)}

A data do início da queda das folhas foi considerada quando $50 \%$ das plantas iniciaram a queda das folhas e o final da queda das folhas quando $50 \%$ das plantas não apresentaram folhas.

Foram utilizadas as datas fenológicas do início e do fi nal da brotação, floração, maturação e queda das folhas, dos anos agrî colas de $1965 / 66$ a $1977 / 78$, para todas as cultivares utilizadas, exce to para a cultivar Isabel, na qual utilizaram-se os anos agrícolas de $1973 / 74$ a $1977 / 78$.

Com a série de treze anos de dados coletados foi possível caracterizar, fenologicamente, a data média de seu aparecimento em cada uma das cultivares estudadas. A data de cada um dos estádios 
fenológicos foi comparada com a data de sua ocorrēncia na cultivar Ca bernet franc, uma vez que essa vinífera é cultivada em toda a MRH311, servindo assim, como uma referência fenológica para as demais cultivares.

\subsection{Caracterização térmica}

\subsubsection{Temperatura-base e graus-dia.}

Foi calculado o somatório das unidades térmicas desde o início da brotação à colheita para os treze anos com as temperaturas-base de 10,12 e $14^{\circ} \mathrm{C}$, utilizando-se das equações propostas por VIL LA NOVA et alii (1972) ou seja:

$$
G D=\left|(T m-T b)+\left(\frac{T M-T m}{2}\right)\right| \cdot d i a
$$

quando $\mathrm{Tm}>\mathrm{Tb}$;

$$
G D=\left|\frac{(T M-T b)^{2}}{2(T M-T m)}\right| \cdot d i a
$$

quando $\mathrm{Tm} \leq \mathrm{Tb}$;

$$
\mathrm{GD}=0
$$

quando $\mathrm{Tb} \geq \mathrm{TM}$;

onde $\quad G D=$ graus-dia

$$
\begin{aligned}
& \mathrm{TM}=\text { temperatura mäxima diāria, em }{ }^{\circ} \mathrm{C} \\
& \mathrm{Tm}=\text { temperatura mỉnima diāria, em }{ }^{\circ} \mathrm{C} \\
& \mathrm{Tb}=\text { temperatura-base }
\end{aligned}
$$


Para que se pudesse estabelecer uma variação contínua entre os GD e a temperatura-base,estabeleceram-se equações de regressão entre as temperaturas-base propostas e os graus-dia obtidos no interva lo de 10 a $14^{\circ} \mathrm{C}$. Após, traçou-se um gräfico, do quál selecionaram-se as curvas que se interceptavam num ponto comum, isio é, onde se consegue o menor valor entre a diferença dos extremos e a sua média (PRIMAULT, 1969). Esse feixe de curvas continha sẹte dos treze anos estuda dos. Em seguida calcularam-se os graus-dia corrigidos para uma série de temperaturas-base, utilizando-se das sete equações de regressão, a fim de se estabelecer o menor desvio padrão, em dias, de acordo com a relação proposta por ARNOLD (1959),

$$
S d=\frac{S d d}{X t-T b}
$$

onde $\quad \mathrm{Sd}=$ desvio padrão, em dias

Sdd = desvio padrão, em graus-dia

$\mathrm{Xt}=$ temperatura média do ar de todos os anos considerados, em ${ }^{\circ} \mathrm{C}$

$\mathrm{Tb}=$ temperatura-base, em ${ }^{\circ} \mathrm{C}$.

Considerou-se como temperatura-base para todo o ciclo a que forneceu o menor desvio padrão, em dias (ARNOLD, 1959). Para a determinação desses valores foram utilizados os dados fenológicos da cultivar Cabernet franc, uma vez que esta serviu como referência para a MRH3I1. 

e (3).

\subsubsection{Temperatura ativa}

A temperatura ativa foi determinada pelo somatório das temperaturas médias diārias superiores a Tb (BRANAS et alii, 1946).

$$
\mathrm{Ta}=\Sigma \mathrm{tm}
$$

onde $\mathrm{Ta}=$ temperatura ativa do período considerado $\Sigma \mathrm{tm}=$ somatōrio das temperaturas médias diärias superiores a $\mathrm{Tb}$.

\subsection{Produto hel iotérmico}

o produto heliotérmico foi calculado atravēs das somas de temperaturas eficazes pelas horas de luz que ocorreram durante o período considerado (BRANAS et alii, 1946).

$$
\mathrm{PH}=\mathrm{X} \cdot \mathrm{H} \cdot 10^{-6}
$$

onde, $\quad \mathrm{PH}=$ produto heliotérmico do período considerado

$$
X \text { = somatório das temperaturas eficazes, ou seja somatório de }
$$
$\mathrm{tm}-\mathrm{Tb}$

$H=$ somatörio das horas de luz (fotoperíodo)

$10^{-6}=$ artificio para reduzir os valores obtidos. 


\subsection{Coeficiente hidrotérmico para o desenvolvimento de fungos}

o coeficiente hidrotérmico foi calculado através da soma dos produtos mensais das temperaturas mëdias e da quantidade de chuva, divididos pela duração, em dias, do período favorável à infecção do fungo (ZULUAGA et alii, 1971).

$$
\mathrm{CH}=\frac{\sum \mathrm{tm} \cdot \mathrm{h}}{\mathrm{N}}
$$

onde, $\quad \mathrm{CH}=$ coeficiente hidrotérmico

$$
\begin{aligned}
\Sigma \mathrm{tm} & =\text { somatōrio da temperatura média mensal, em }{ }^{\circ} \mathrm{C} \\
\mathrm{h} & =\text { altura pluviométrica mensal, em mm } \\
\mathrm{N} & =\text { nụmeros de dias do período favorável à infecção. }
\end{aligned}
$$

3.8. Caracterização hel iohidrotērmica

\subsubsection{Indice bioclimātico de Constantinescu}

0 indice bioclimätico foi calculado através da expres são (CONSTANTINESCU, 1967).

$$
\mathrm{Ibc}=\frac{\mathrm{Ct} \cdot \mathrm{Ci}}{\mathrm{Cp}_{\mathrm{p}} \cdot 10}
$$

sendo: $\quad C t=\frac{\sum \mathrm{T}_{\mathrm{a}}}{\mathrm{N}}, \quad \mathrm{Ci}=\frac{\sum \mathrm{Ie}}{\mathrm{N}}$ e $\quad \mathrm{Cp}=\frac{\sum \mathrm{Pa}}{\mathrm{N}}$, que resulta, 
$I b c=\frac{\frac{\Sigma \mathrm{Ta}}{\mathrm{N}} \cdot \frac{\sum \mathrm{Ie}}{\mathrm{N}}}{\frac{\Sigma \mathrm{Pa}}{\mathrm{N}} \cdot 10}=\frac{\sum \mathrm{Ta} \cdot \sum \mathrm{Ie}}{\sum \mathrm{Pa} \cdot \mathrm{N} \cdot 10}$

onde $\quad I b c=$ Indice bioclimático do período considerado

$$
\begin{aligned}
\mathrm{Ct} & =\text { coeficiente de temperatura } \\
\mathrm{Ci} & =\text { coeficiente de insolação } \\
\mathrm{Cp} & =\text { coeficiente de precipitação } \\
\Sigma \mathrm{Ta} & =\text { somatório da temperatura ativa mēdia diāria } \\
\Sigma \mathrm{Ie} & =\text { somatōrio da insolação média diāria } \\
\Sigma \mathrm{Pa} & =\text { somatōrio da precipitação média diāria } \\
\mathrm{N} & =\text { número de dias do período favorāvel }
\end{aligned}
$$

3.8.2. Quociente heliopluviométrico de maturação

o quociente heliopluviométrico de maturação foi calcu lado atravēs da relação entre a insolação efetiva acumulada e a precipitação que ocorreu durante o período compreendido entre a mudança de cor à colheita das uvas (WESTPHALEN, 1977).

$$
\mathrm{QM}=\frac{\Sigma \mathrm{Ie}}{\Sigma \mathrm{P}}
$$

onde, $\quad Q M=$ quociente heliopluviométrico de maturação

$$
\begin{aligned}
\Sigma I e & =\text { somatório da insolação efetiva } \\
\Sigma P & =\text { somatório da precipitação }
\end{aligned}
$$


Para a caracterização hidrotérmica e heliohidrotërmica foram utilizados dados de cinco anos agrícolas, diferenciados segun do o total de precipitação pluviométrica ocorrida durante o período compreendido entre a brotação e o final da maturação, cujos valores cres cem na seguinte ordem: 1969/70 foi o de menor precipitação pluvial $(496,8 \mathrm{~mm}), 1977 / 78(619,9 \mathrm{~mm}), 1967 / 68(687,3 \mathrm{~mm}), 1965 / 66(1180,2 \mathrm{~mm})$ e $1972 / 73$ foi o que apresentou a maior precipitaçăo pluvial (1335,7mm). 


\section{RESULTADOS E DISCUSSAOO}

\subsection{Fenologia}

\subsubsection{Início ao final da brotação (IB-FB)}

A tabela 2 e a figura 1 apresentam as datas médias do início e do final da brotação para as cultivares em estudo. A cultivar mais precoce para iniciar a brotação foi a Isabel (30/8), seguida pelas cultivares Semillon (05/9), Cabernet franc (06/9), Bonarda (07/9), Riesling itälico (10/9), Merlot (11/9), Barbera e Trebbiano (14/9), Pe tit Syrah e Malvasia de Lipari (16/9), e a mais tardia a Moscatel bran co $(22 / 9)$.

Observa-se que ocorreu uma diferença de 23 dias entre a data média do início da brotação da cultivar mais precoce em relação ao início de brotação da mais tardia e uma diferença de 20 dias entre 


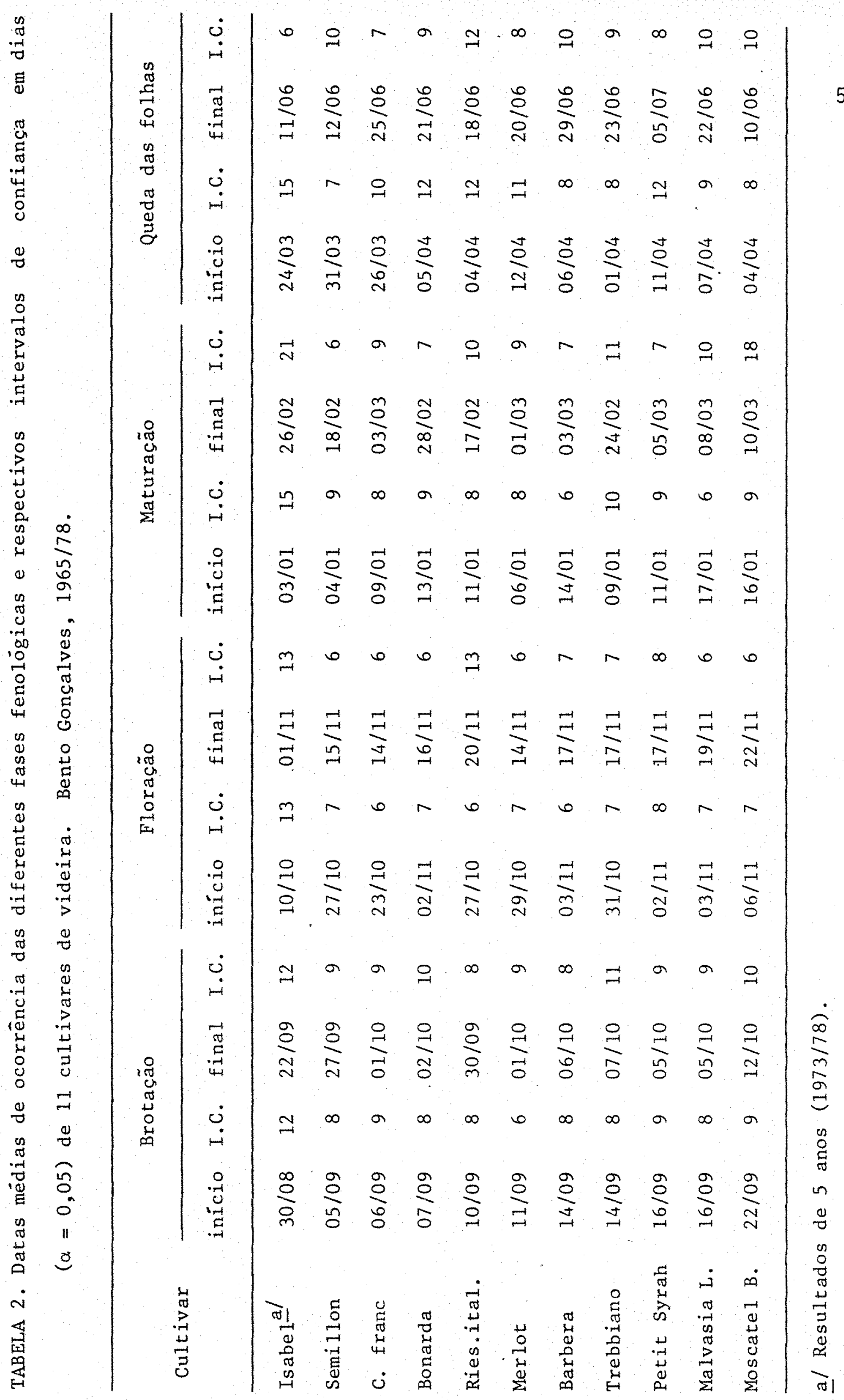


59.

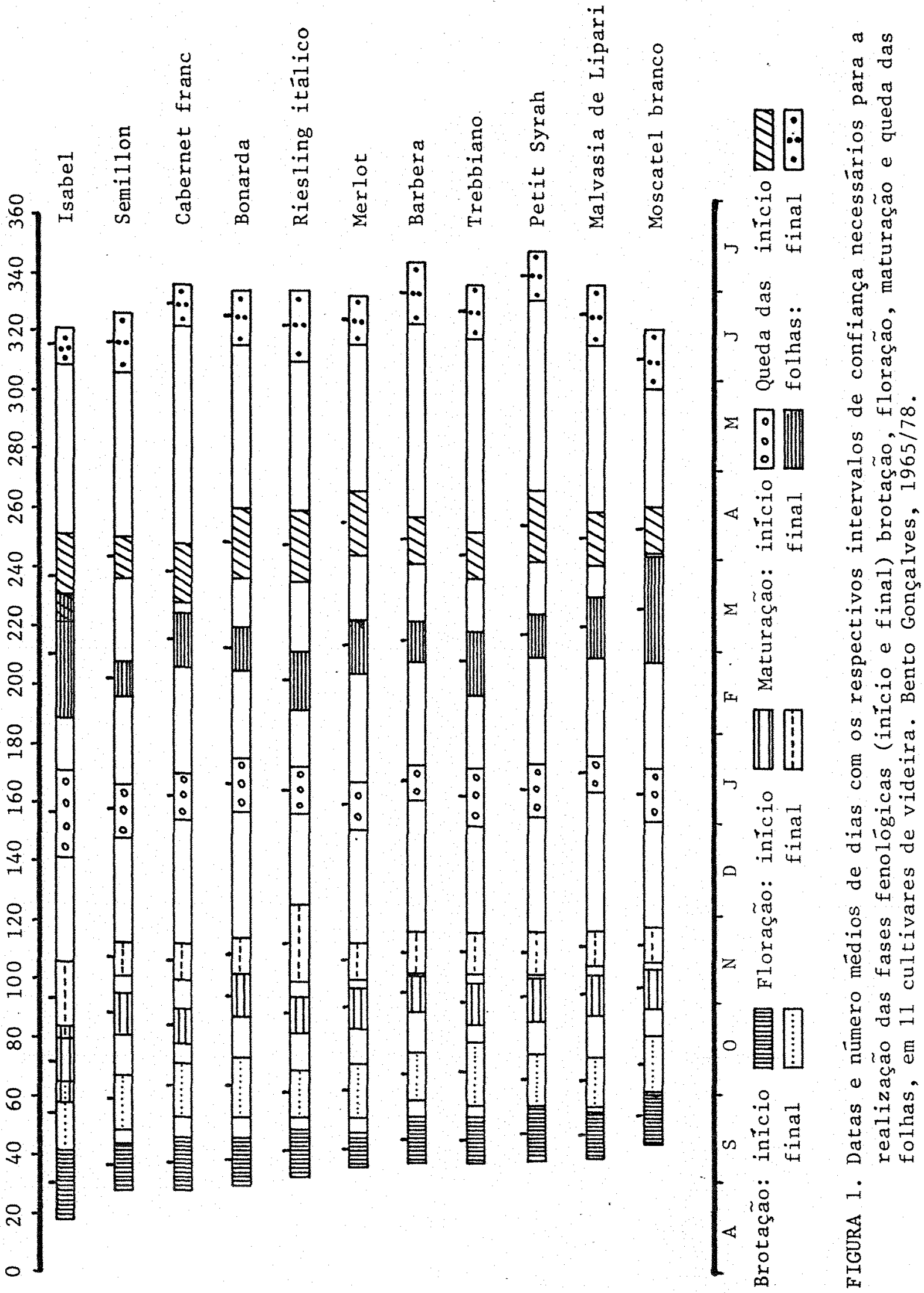


- final da brotação da mais precoce em relação à mais tardia. Essas cul tivares podem ser divididas em três grupos: a) precoces, quando brotam an tes ou junto com a Semillon; b) médias, quando brotam até 15 dias apös a Semillon; c) tardias quando brotam 15 ou mais dias após as médias. Seguindo-se essa classificação, são consideradas cultivares precoces a Isabel e a Semillon; mëdias a Cabernet franc, Bonar da, Riesling itälico, Merlot, Barbera, Trebbiano, Petit Syrah e Malvasia de Lipari; e tardia a Moscatel branco. GOBBATO (1940), para Caxias do Sul, considerou como cultivares de brotação precoce a Riesling itálico, Barbera e Bonarda; de brotação média a Merlot, Semillon e Cabernet franc, e tardias a Trebbiano e a Moscatel branco. DIAS (1959) tam bëm considerou como preccce a cv. Bonarda. VEGA (1969), para a Argenti na, considerou como cultivar precoce a Merlot, tardia a Cabernet franc e mais tardia a Trebbiano. SOUZA (1969) considerou a cv. Bonarda de brotação precoce e a cv. Cabernet franc de brotação tardia.

A tabela 3 e a figura 2 mostram que o número de dias necessários entre o inficio e o final da brotação foi em mëdia de 22 dias, confirmando as observações de BRANAS et alii (1946) de que as ge mas de uma planta não iniciam a brotação ao mesmo tempo e que essa va riação è devida aos diferentes níveis de dormência em que elas se encontram (Nigond, 1967 citado por GALET, 1983). A cv. Moscatel branco realizou esta fase em 18 dias, enquanto a cv. Cabernet franc necessitou de 26 dias. 


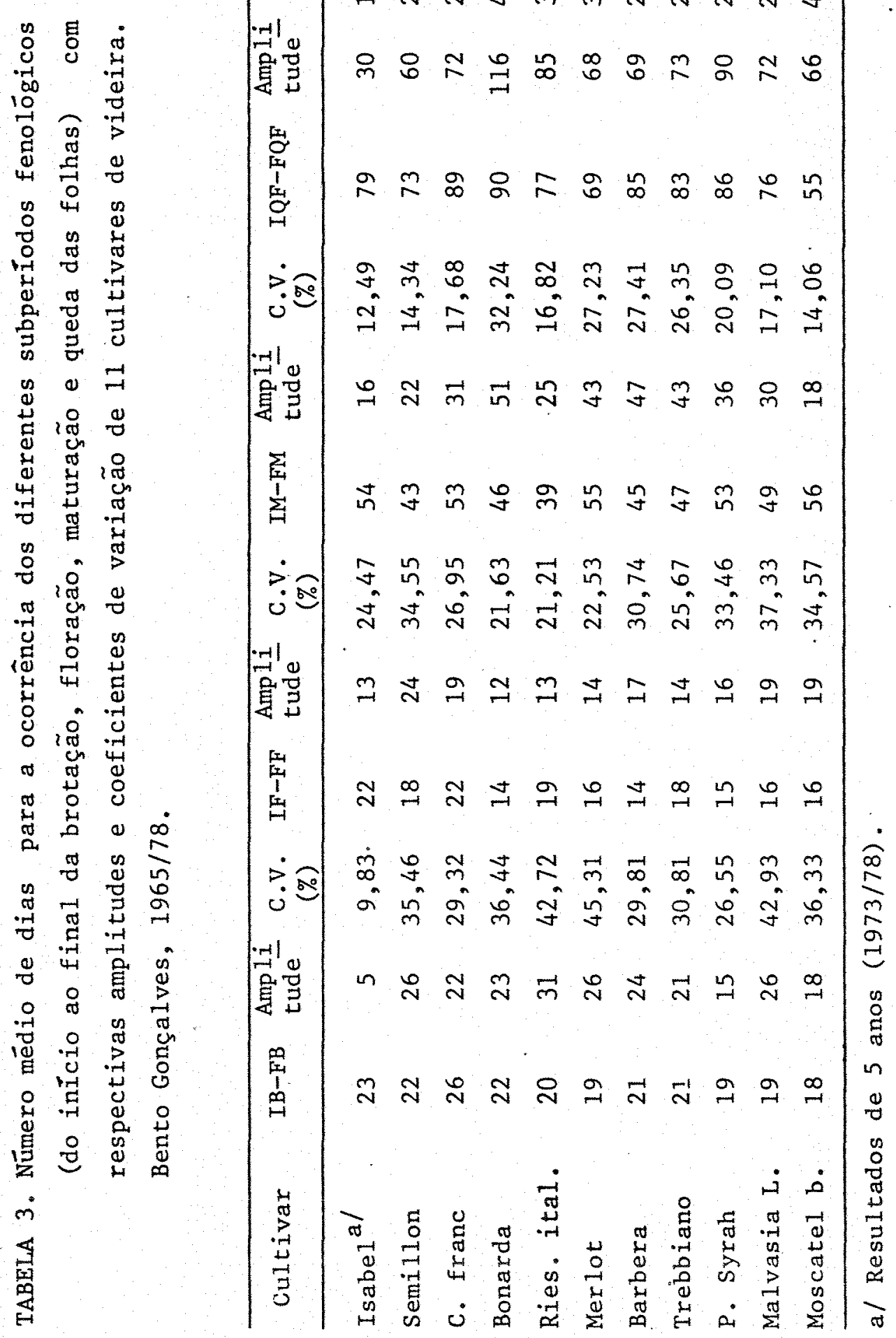


62.
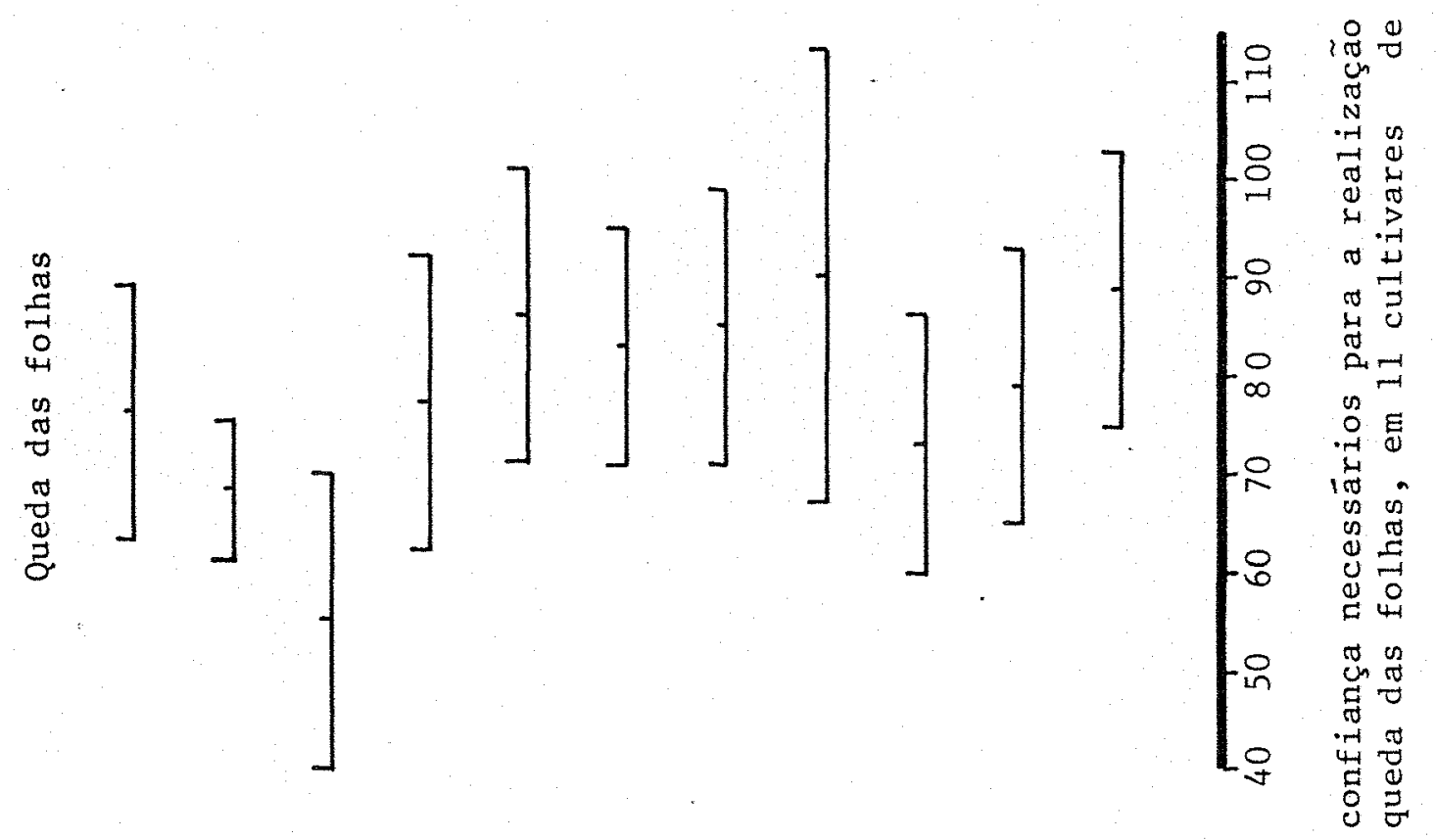

兽 $]$

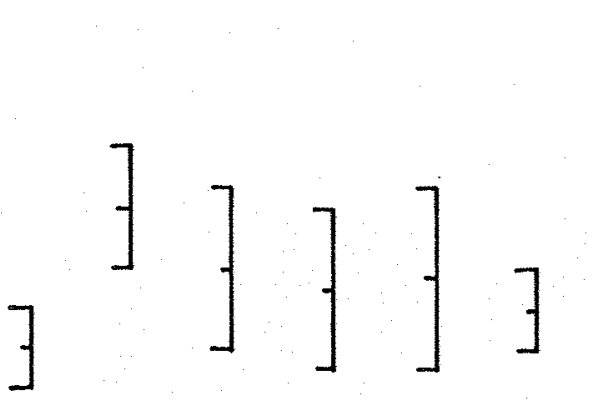

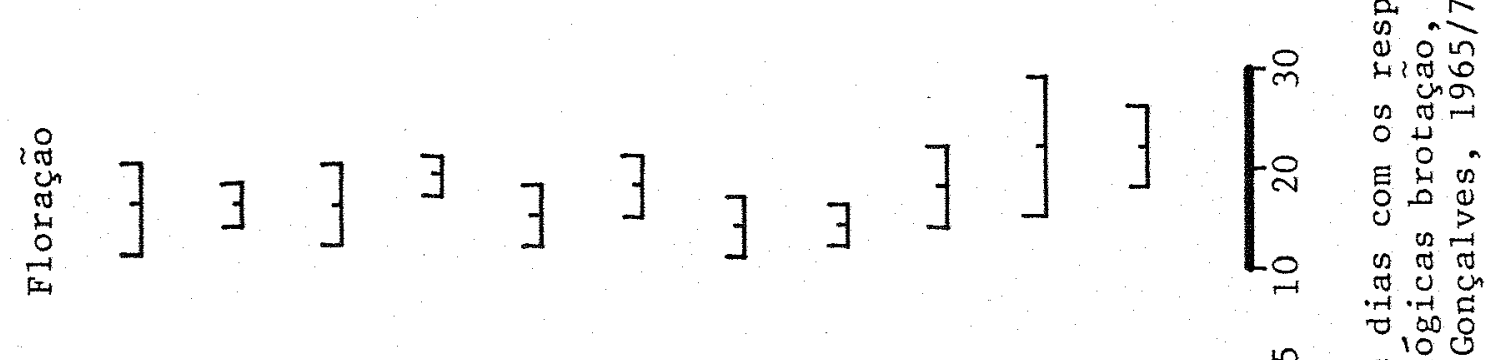

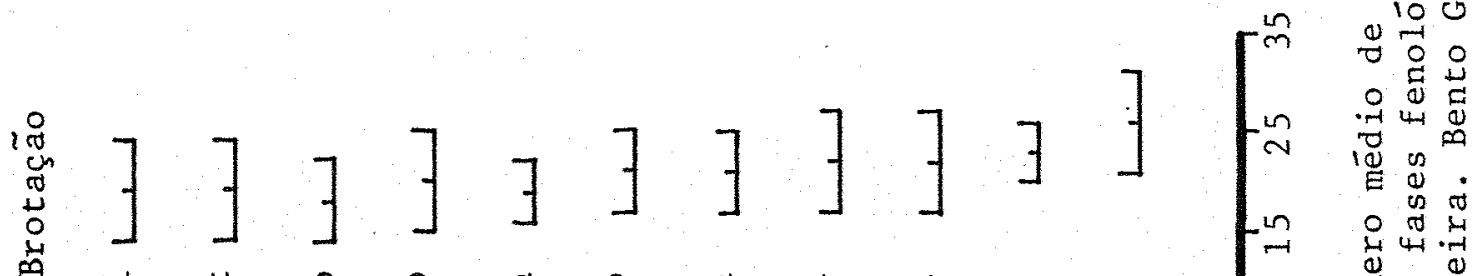

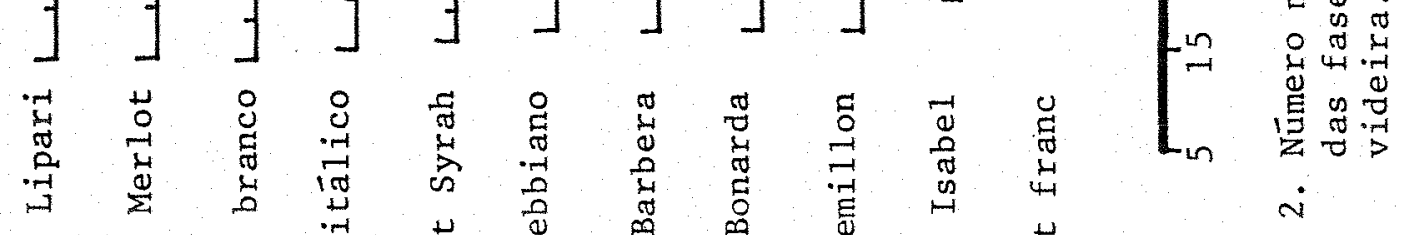

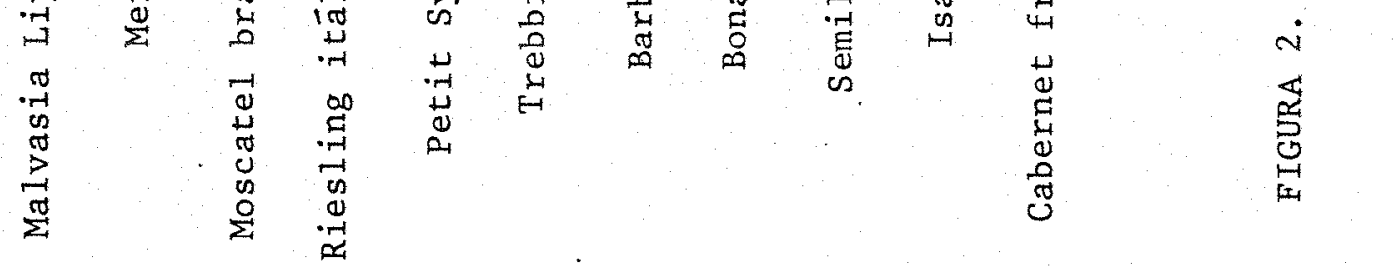


Essas diferenças apresentadas quanto a época de brota çäo são devidas a constituição genética de cada planta, mas estão subordinadas às condições climáticas do local, principalmente através da temperatura mẻdia. A temperatura mẻdia é influenciada pela latitude (TAMARO, 1920; BRANAS, 1974; COSTACURTA e ROSELLI, 1980), pela altitude (TAMARO, 1920; GALET, 1983), pela exposição topogräfica e insolação. Cepas jovens ou fracas antecipam a data do início da brotação, ao passo que cepas vigorosas atrasam-na (BRANAS et alii, 1946). O solo, através de sua coloração, textura e profundidade tambêm influencia a brotação (Ochoa, 1962 citado por VEGA, 1969).

Comparando-se a data mëdia de início da brotação das cultivares estudadas com aquelas de regiões próximas ou em países limí trofes com o local em estudo, constata-se que VASCONCELLOS (1930) encontrou como datas médias para Piracicaba, 14/9 para a cv. Isabe1, $12 /$ 9 para a cv. Malvasia e $17 / 9$ para a cv. Trebbiano. GoBBATO (1940) encontrou como datas médias, para Caxias do Sul, $18 / 9$ para a cv. Merlot, $19 / 9$ para a cv. Cabernet franc e 02/10 para a cv. Trebbiano. ZULUAGA et alii (1971) encontraram para a viticultura argentina as datas médias de 18/9 para a cv. Riesling itālico, 27/9 para a cv. Merlot, 28/9 para a cv. Bonarda, $30 / 9$ para a cv. Trebbiano e 02/10 para a cv. Caber net franc. DIAS et alii (1982) comentam que, para Bento Gonçalves, a cv. Semillon inicia a brotação nos últimos dias de agosto e a cv. Cabernet franc no segundo decèndio de setembro.

Vê-se que as localidades próximas ao local estudado a presentaram datas fenológicas semelhantes às que foram determinadas no 
presente estudo, ao passo que quando comparadas com as existentes na Argentina, apresentaram uma antecipação de atë três semanas, devido, principalmente, ao efeito da latitude sobre a temperatura média.

As figuras 3 a 8 representam, parz cada ano, as datas de ocorrência (início e final) dos diversos estädios fenológicos para as onze cultivares em estudo. Verifica-se que houve uma variação bastante grande, ao longo dos anos, entre as datas do início da brotação para uma mesma cultivar, mas que o comportamento fenolögico entre as diferentes cultivares apresentou uma homogeneidade entre os diversos a nos estudados. Nos anos agrícolas de 1965/66, 1968/69, 1976/77 e 1977/ 78 a data do início da brotação foi antecipada para todas as cultivares, quando comparadas com as respectivas datas médias, enquanto que nos anos agrícólas de 1966/67, 1970/71, 1972/73 e 1973/74 ocorreu um retardamento na data do início da brotação.

Isso vem confirmar que o comportamento fenológico das diferentes cultivares, quanto a brotação, obedecem a um mesmo fator do ambiente, a temperatura do ar (BRANAS et alii, 1946; POUGET, 1966; COS TACUR'AA e ROSELLI, 1980).

A classificação baseada na época de brotação é importante para os viticultores, pois permite que os mesmos possam explorar cultivares de brotação tardia em regiões em que se verificam geadas tardias (GOBBATO, 1940). Os viticultores da MRH311 localizados em locais propensos às geadas tardias, retardam a época de realização da po da de inverno e com isso atrasam por alguns dias a data do início da 


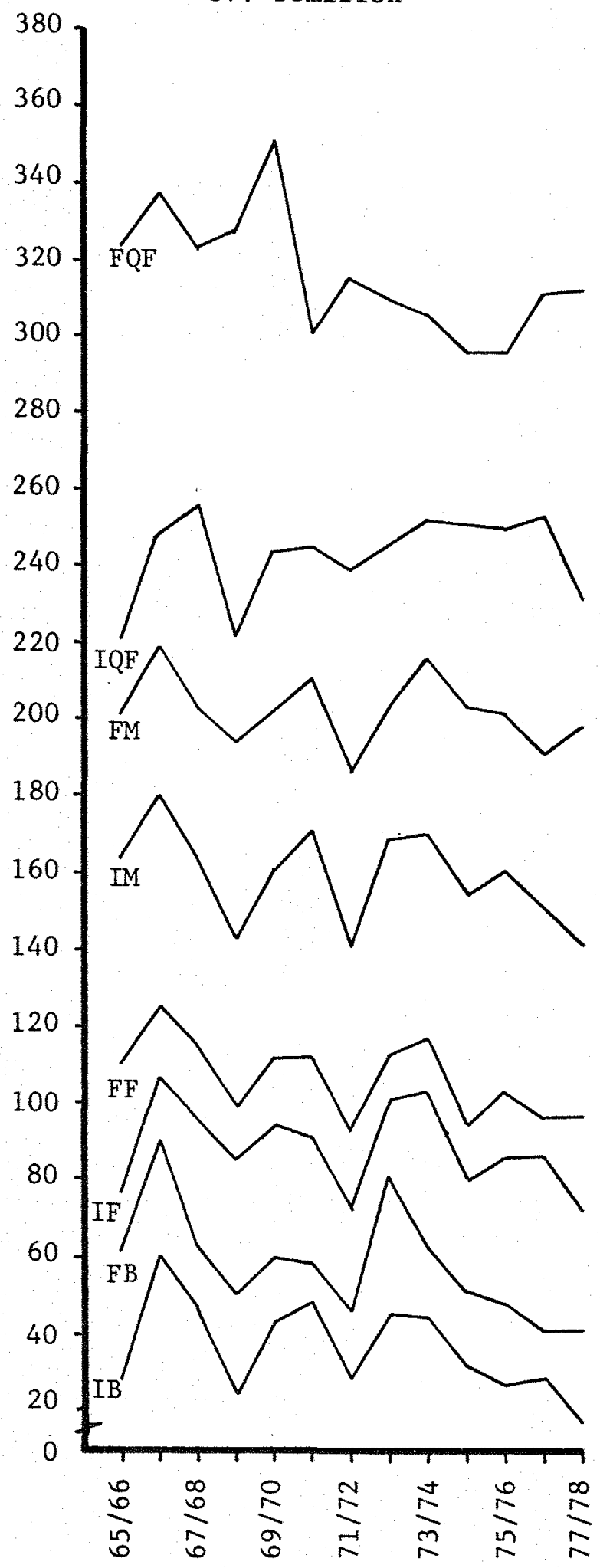

cv. Barbera
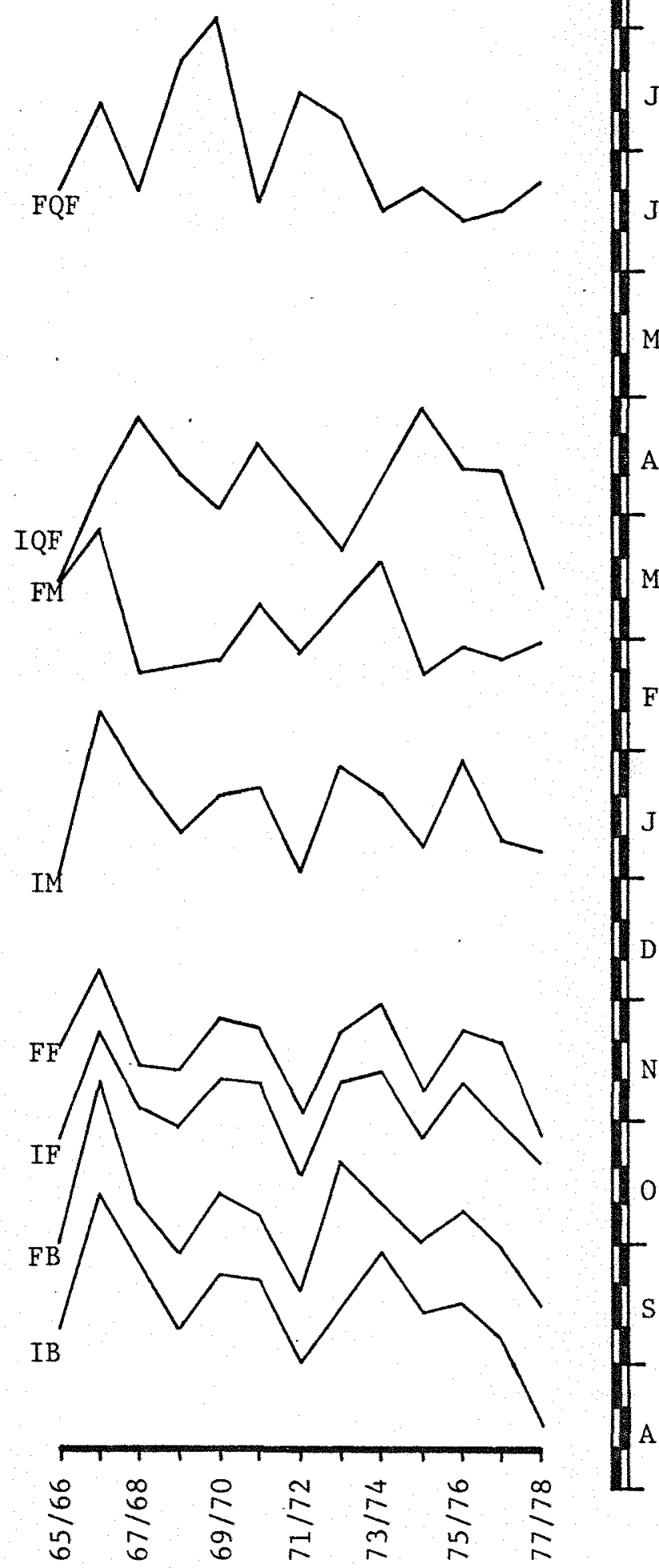

FIGURA 3. Datas de ocorrência dos estádios fenolögicos, início da brotação (IB), final da brotação (FB), início da floração (IF), final da floração (FF), início da maturação (IM), final da maturação (FM), início da queda das folhas (IQF) e final da queda das folhas (FQF) para as cultivares Semillon e Barbera. Bento Gonçalves, 1965/78. 
66.
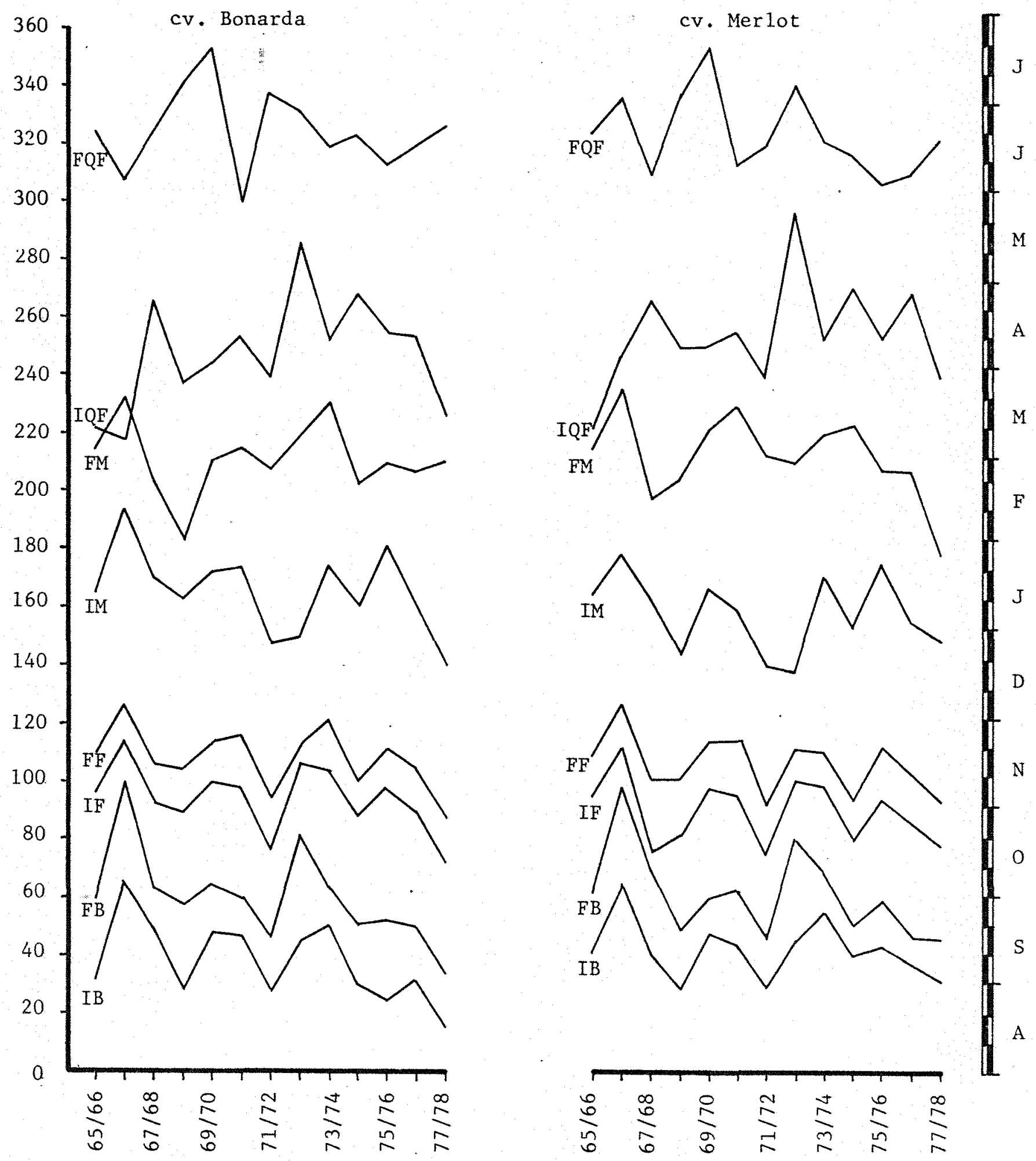

FIGURA 4. Datas de ocorrência dos estâdios fenolögicos, inîcio da brotação. (IB), final da brotação (FB), início da floração (IF), final da floração (FF), início da maturação (IM), final da maturação (FM), início da queda das folhas (IQF) e final da queda das folhas ( $F Q F$ ) para as cultivares Bonar da e Merlot. Bento Gonçalves, $1965 / 78$. 

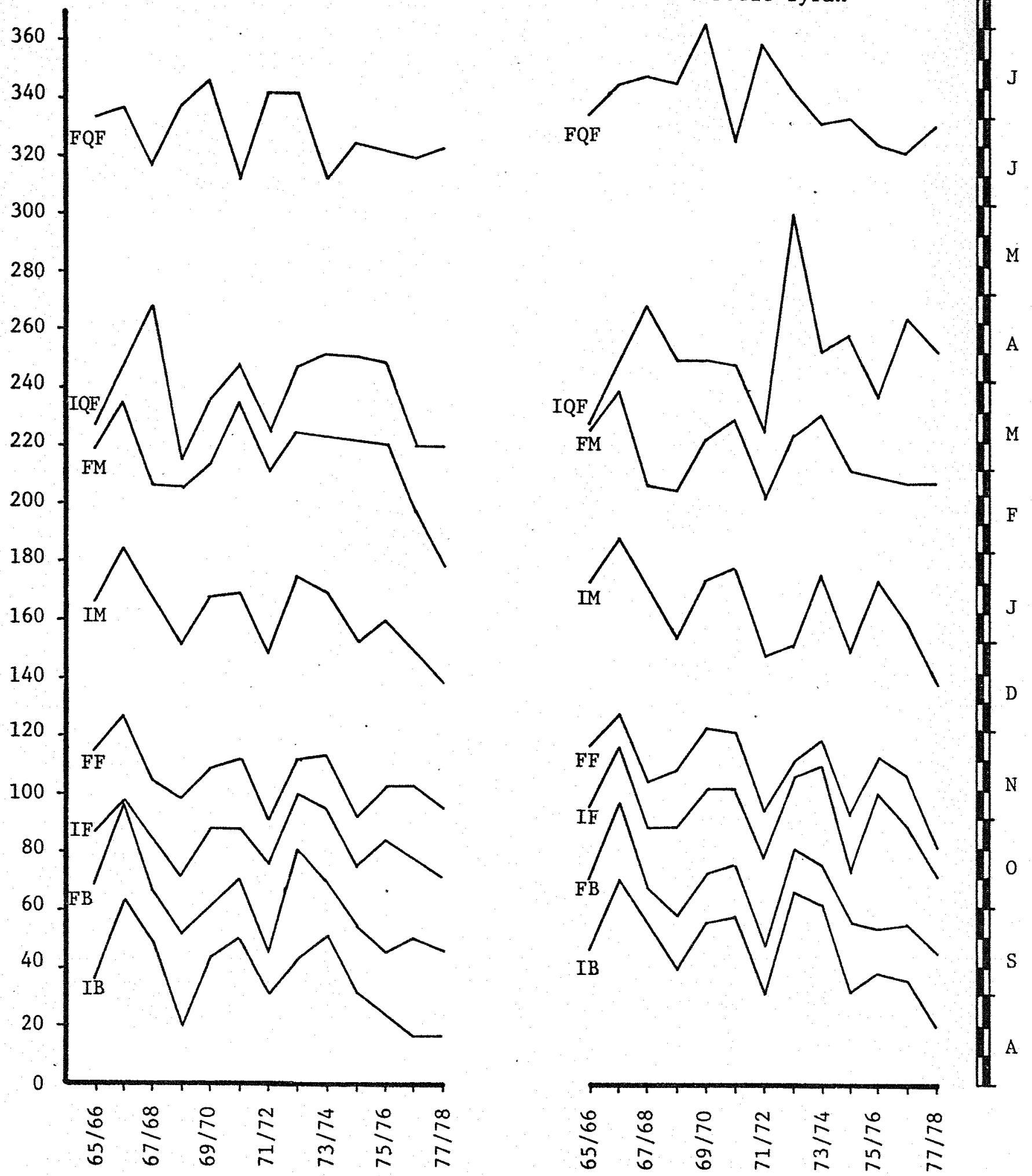

FIGURA 5. Datas de ocorrência dos estâdios fenológicos, inîcio da brotação (IB), final da brotação (FB), início da floração (IF), final da floração (FF), início da maturação (IM), final da maturação (FM), início da queda das folhas (IQF) e final da queda das folhas (FQF) para as cultivares Caber net franc e Petit Syrah. Bento Gonçalves, 1965/78. 
cv. Riesling itälico

cv. Trebbiano
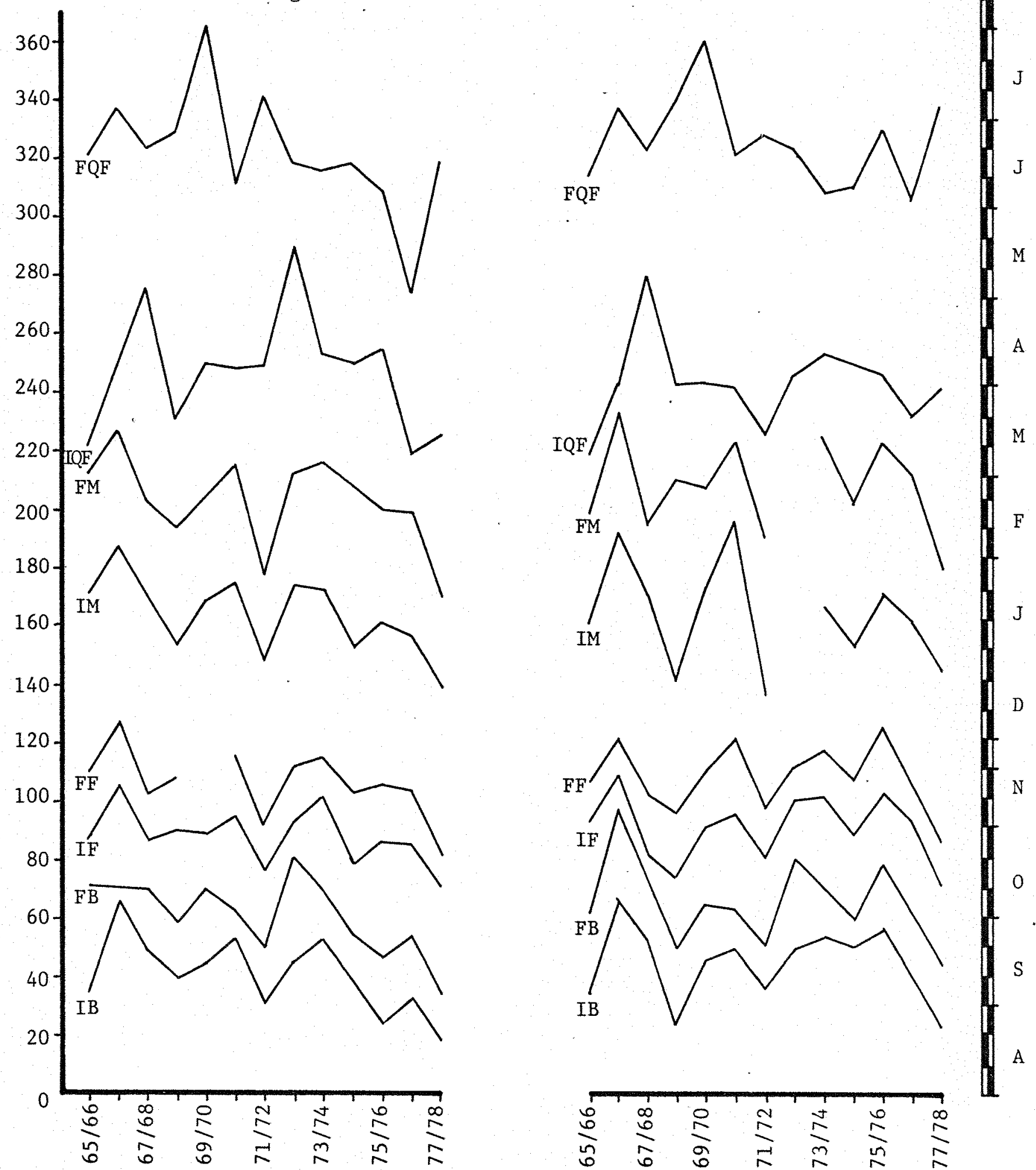

FIGURA 6. Datas de ocorrência dos estädios fenológicos, início da brotaçâo. (IB), final da brotação (FB), início da floração (IF), final da floração (FF), início da maturação (IM), final da maturação (FM), início da queda das folhas (IQF) e final da queda das folhas (FQF) para as cultivares Riesling itālico e Trebbiano. Bento Gonçalves, 1965/78. 
cv. Malvasia de Lipari
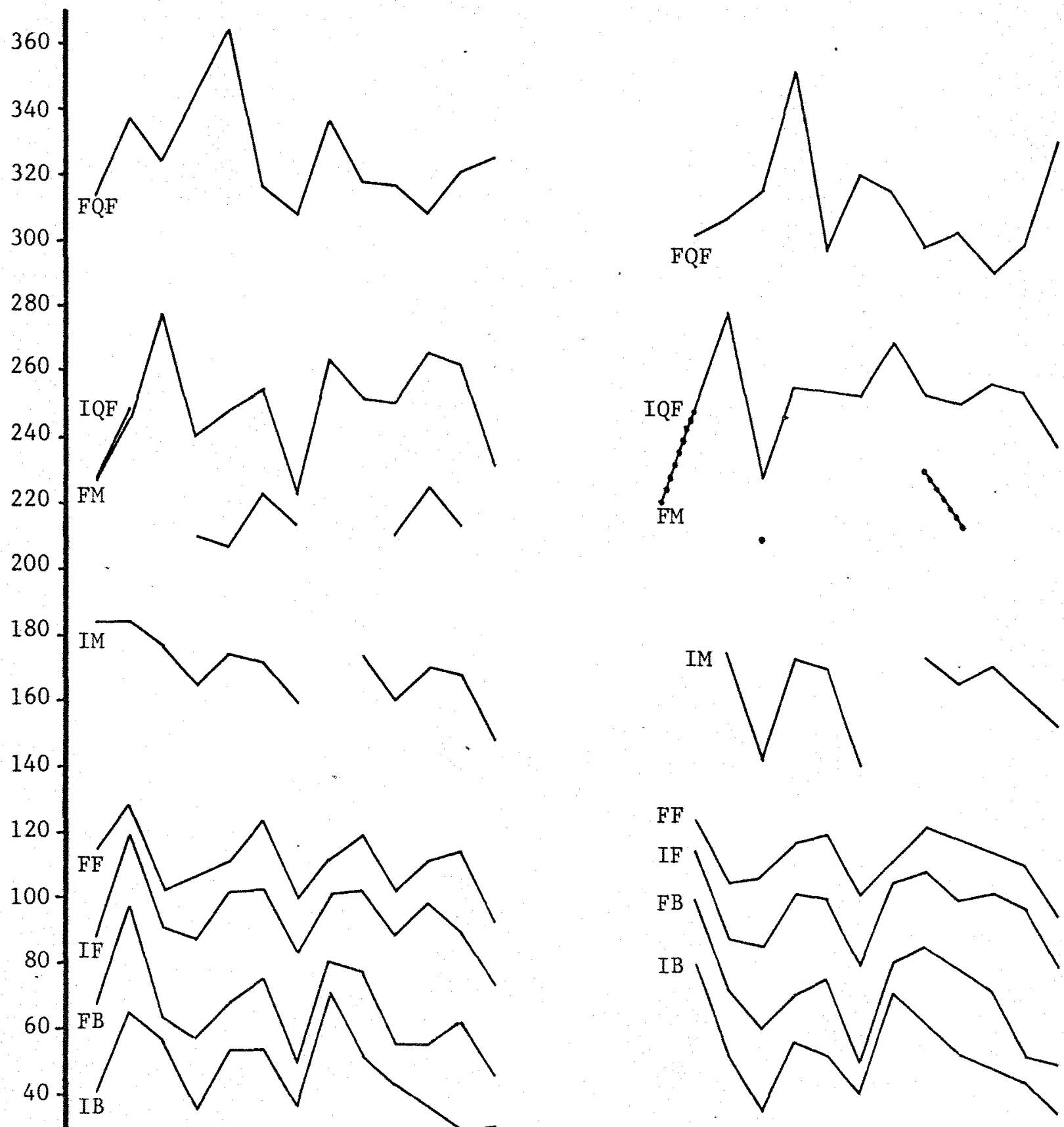

$\mathrm{D}$
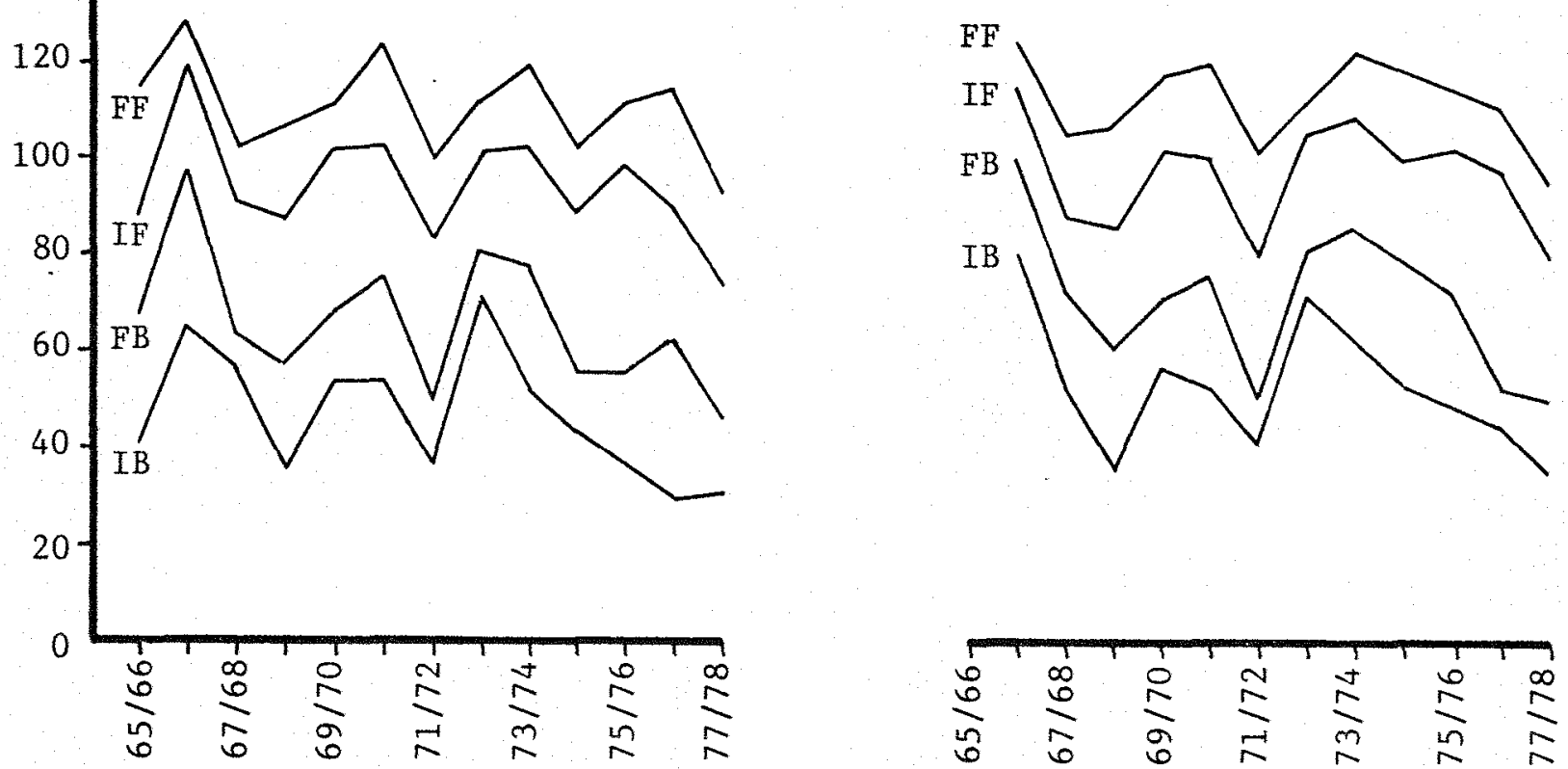

FIGURA 7. Datas de ocorrēncia dos estádios fenológicos, início da brotação. (IB), final da brotação (FB), início da floração (IF), final da floração (FF), início da maturação (IM), final da maturação (FM), início da queda das folhas (IQF) e final da queda das folhas (FQF) para as cultivares Malvasia de Lipari e Moscatel branco. Bento Gonçalves, 1965/78. 


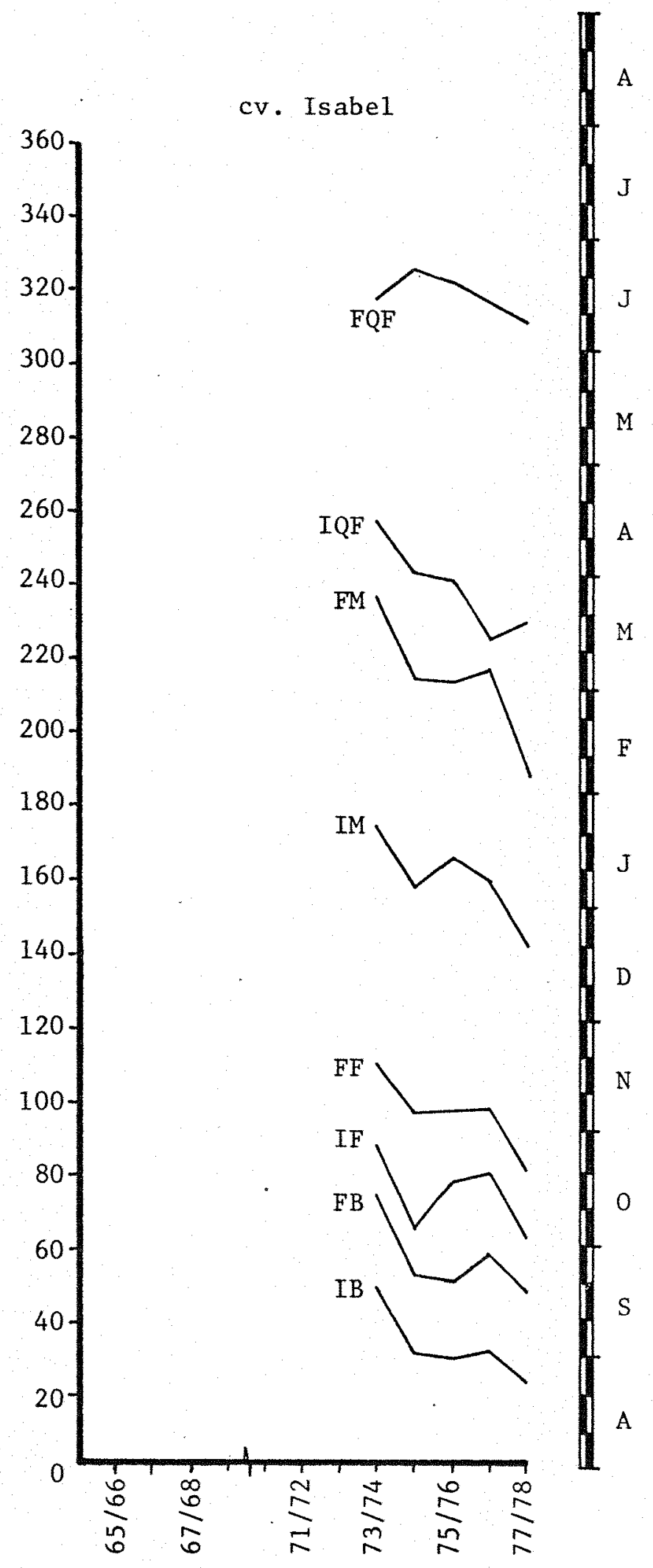

FIGURA 8. Datas de ocorrência dos estãdios fenológicos, inīcio da brotação (IB), final da brotação (FB), início da floração (IF), final da floração (FF), início da maturação (IM), final da maturação (FM), início da queda das folhas (IQF) e final da queda das folhas (FQF) para a cultivar Isabel. Bento Gonçalves, 1973/78. 
brotaçäo fugindo, muitas vezes, dos danos dessas geadas. o porta-enxer to e o sistema de condução empregados podem retardar, por alguns dias, o início da brotaçäo (RIO GRANDE DO SUL, 1978; GALET, 1983).

A data do início da brotação é uma decorrência do re pouso hibernal a que foi submetida a planta (CALó e COSTACURTA, 1974). Sendo assim, procurou-se estabelecer uma correspondência entre o perío do de repouso e a data do inîcio da brotação, uma vez que, como afirma POUGET (1972), a quebra da dormência só è possível quando ocorrerem se te dias consecutivos com temperaturas médias abaixo de $10^{\circ} \mathrm{C}$ e que esse processo ocorre, para a Europa, em novembro, que corresponderia ao mês de maio para o hemisfério sul. Verificou-se que, em maio, apenas um dos treze anos (1968/69) apresentava essa exigência, três anos em junho $(1967 / 68,1971 / 72$ e 1976/77) e um ano em julho $(1969 / 70)$. CARBONNEAU (1982) diz que, para Bento Gonçalves, a quebra da dormència se realiza após a queda das folhas, devido ao frio e às geadas do outono-inverno. Calcularam-se, então, os graus-dia para esse período (início da queda das folhas à brotação) e os resultados encontrados não apresentaram $\underline{u}$ ma correspondéncia entre graus-dia acumulados e a data do início da brotação. Por isso, separou-se o período de repouso em värios subperío dos e desta forma encontrou-se uma correspondência entre a data do in cio da brotação e os graus-dia acumulados. A tabela 4 mostra a data do início da brotação para cada cultivar e os graus-dia acumulados de 19 de maio a 15 de junho. Observa-se que, quando o nümero de graus-dia a cumulados foi menor que 175 (temperatura-base de $12^{\circ} \mathrm{C}$ ), a cultivar ini 


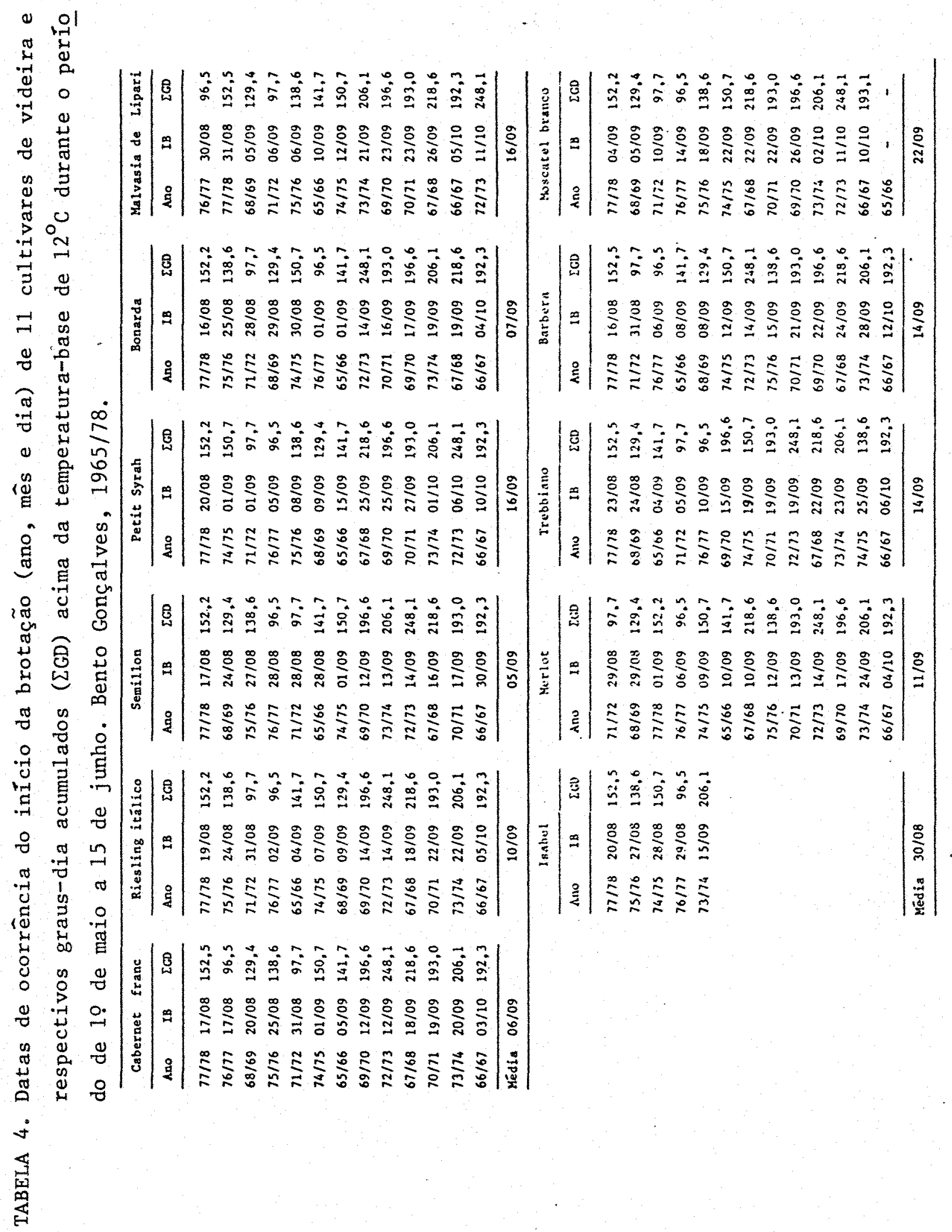


çiou a brotação antes de sua data média; quando o valor de graus-dia a cumulados ultrapassou esse valor, ela iniciou a brotação após a sua da ta mëdia. As cultivares Cabernet franc, Riesling itälico, Semillon, Pe tit Syrah, Bonarda, Malvasia de Lipari e Isabel confirmaram essa tendência em todos os anos. Para as cultivares Merlot, Barbera, Trebbiano e Moscatel branco não houve a tendência em apenas um ano.

\subsubsection{Inĩcio ao final da floração (IF-FF)}

Na tabela 2 e na figura 1 são apresentadas as datas mé dias do início da floração, nas quais observa-se uma diferença de 27 dias entre a data média da floração mais precoce em relação à mais tar dia e uma diferença de 21 dias entre o final da floração mais precoce em relação à mais tardia. A sequência do início da floração foi: cv. I sabel (10/10), cv. Cabernet franc (23/10), cvs. Riesling itälico e Se millon (27/10), cv. Merlot (29/10), cv. Trebbiano $(31 / 10)$, cvs. Bonarda e Petit Syrah (02/11), cvs. Barbera e Malvasia de Lipari (03/11) e cv. Moscatel branco $(06 / 11)$.

Analisando-se a tabela 2 e as figuras 3 a 8 , constata-se que as cultivares precoces para a brotação apresentaram-se tambēm precoces para a floração, embora a sequência da brotação, entre as cuI tivares, não tenha sido a mesma para a floração.

A tabela 3 e a figura 2 mostram que o número de dias $\underline{e}$ xigidos entre o início e o final da floração foi, em média, 17 dias; as 
cvs. Barbera e Bonarda realizaram essa fase em 14 dias, enquanto que as cvs. Isabel e Cabernet franc, em 22 dias.

VASCONCELLOS (1930) comenta que, em Piracicaba, a flo ração ocorre em $10 / 10$ para as cvs. Isabel e Malvasia e 06/10 para a Trebbiano. GoBBATO (1940) diz que, para Caxias do Sul, a floração média da cv. Merlot ocorre em 03/11, para a cv. Trebbiano em $17 / 11$ e em 05/11 para a Cabernet franc. DIAS (1959) comenta que, para Caxias do Sul, as cvs. Bonarda e Cabernet franc florescem na primeira década de novembro. ZULUAGA et alii (1971) consideraram, para a viticultura argentina, as seguintes datas: cv. Riesling itälico 02/11, cv. Trebbiano 09/11, cv. Merlot 07/11, cv. Cabernet franc 08/11, cv. Bonarda 09/11. BĀN (1979) comenta que as datas mëdias para o início da floração das cultivares Cabernet franc, Isabel e Merlot, para Bento Gonçalves, são, respectivamente, $17 / 10,16 / 10$ e $24 / 10$ e para o final da floração 11/11, $03 / 11$ e $09 / 11$.

Constata-se, portanto, que as datas médias determinadas para a floração são bastante semelhantes às relatadas em trabalhos realizados em localidades próximas. Na comparação com localidades argentinas, observou-se uma melhor proximidade das datas médias de flo ração em relação às datas do início da brotação, referidas anteriormente. 


\subsubsection{Inĩcio ao final da maturação (IM-FM)}

A data do início da maturação nem sempre é determinada com precisão, principalmente nas cultivares de película branca, uma vez que a mudança de coloração do fruto se processa lentamente e não é tão nítida como nas cultivares de película tinta.

A tabela 2 e a figura 1 apresentam as datas médias do iníció da maturação (mudança de cor das bagas), nas quais observa-se u ma diferença de 14 dias entre a data média do início da maturação mais precoce em relação à mais tardia e uma diferença de 21 dias entre o fi nal da maturação (colheita) da mais precoce em relação à mais tardia. A cultivar Riesling itälico (17/2) foi a mais precoce para a maturação dos frutos; seguida pela cv. Semillon (18/2), cv. Trebbiano (24/2), cv. Isabel (26/2), cv. Bonarda (28/2), cv. Merlot (01/03), cvs. Cabernet franc e Barbera (03/3), cv. Petit Syrah $(05 / 3)$, cv. Malvasia de Li pari $(08 / 3)$ e cv. Moscatel branco (10/3).

A tabela 3 e a figura 2 mostram que o nümero de dias necessārios entre o início e o final da maturação foi, em média, de 49 dias. A cultivar Riesling itälico necessitou de 39 dias para realizar essa fase, enquanto a cultivar Moscatel branco, 56 dias.

Voltando-se a comparar as datas médias do início e do final da maturação das cultivares estudadas com aquelas de regiões pró ximas, constata-se que, VASCONCELLOS (1930) determinou para Piracicaba que a maturação ocorreu em $08 / 1$ para a cv. Trebbiano, $13 / 1$ para a cv. 
Isabel e 19/1 para a cv. Malvasia. GOBBATO (1940), para Caxias do Sul, considerou como data para a maturação das cultivares Merlot, Trebbiano e Cabernet franc, 09/3, 22/3 e 12/3, respectivamente. DIAS (1959) afir ma que as cultivares Bonarda e Cabernet franc maturam nos primeiros dias de março. SOUZA (1969) comenta que a cv. Merlot matura em feverei ro, enquanto a cv. Trebbiano matura na primeira quinzena de março. Pa ra a Argentina ZULUAGA et alii (1971) consideraram que as cultivares a tingem a maturação industrial quando $21^{\circ}$ de açücares estão acumulados nas uvas e que a data mëdia para que isso ocorra é $05 / 2$ para a $\mathrm{cv}$. Riesling itálico, $25 / 3$ para a cv. Trebbiano, 15/2 para a cv. Merlot, 05/3 para a cv. Cabernet franc e 05/4 pará a cv. Bonarda.

BĀN (1979) determinou, para Bento Gonçalves, que o i nício e o final da maturạção para as cvs. Merlot, Isabel e Cabernet franc foram 02/1, 03/1, 28/12 e 23/2, 01/3 e 14/2, respectivamente. DIAS et alii (1982) consideraram como data mëdia para a maturação da cv. Semillon o segundo decêndio de fevereiro e o primeiro decêndio de março para a cv. Cabernet franc, isso para Bento Gonçalves, enquanto que, para Caxias do Sul, a cv. Semillon maturou no terceiro decêndio de fevereiro e a cv. Cabernet franc no segundo decêndio de março.

Constata-se, através das figuras 3 a 8 que, para a mes ma cultivar, continuam ocorrendo as mesmas variações, ao 1ongo dos anos, entre as datas de início e do final da maturação, embora o compor tamento fenológico nas diferentes cultivares apresentem uma certa homo geneidade entre os diversos anos estudados. A data do início da matura 
ção foi antecipada para todas as cultivares nos anos agrícolas de 1971/ 72 e 1977/78, e para a maioria no ano agrícola 1968/69, quando compara das com as respectivas datas médias. Para os anos agrícolas de 1966/67, 1970/71 e 1973/74, ocorreu um retardamento no inícío da maturação para todas as cultivares. Esses mesmos anos mostraram lim comportamento seme Thante para a data final da maturação.

As condições climäticas, o estado nutricional da plan ta e o número de gemas deixados na poda atuam sobre a data da maturação (VEGA, 1969). Normalmente, plantas com excessiva carga apresentam ma turação irregular e um desequilíbrio na relação quantidade/qualidade . Vinhedos com excesso de adubação nitrogenada apresentam uma vegetação exuberante e uma desproporção entre a parte vegetativa e a produção. A colheita está diretamente associada com as condições climáticas que ocorrem nos dias que antecedem a sua realização. Não são raros os anos em que as uvas chegam às indūstrias com um teor de açücar insuficiente, face às condições desfavorāveis para a maturação (RIZZON e TONIETTO, 1982). A incidência da podridão do cacho acelera a colheita das cultiva res sensiveis a esses fungos. Caso as condições climäticas sejam favoráveis à maturação, os viticultores procuram retardar a data da colhei ta de modo a conseguirem um produto de melhor qualidade e preço.

A maioria dos países vitícolas adotam a clássica esca la de maturação proposta por Pulliat (1879), citado por GALET (1983), ba seada na época de maturação da cultivar Chasselas dorê. ZULUAGA et a1ii (1971) propuseram, para a Argentina, uma escala de maturação baseada na cultivar Semillon. 
Para Bento Gonçalves, foi determinada a data média de maturação da cultivar Chasselas dorē a fim de enquadrar as cultivares estudadas segundo a classificação de Pulliat. Utilizando-se dos dados fenológicos dos anos agrícolas de 1973 a 1978, encontrou-se como data média $13 / 2$. Baseando-se nesta classificação, teremos como cultivares pertencentes ao 39 grupo, ou seja, maturam de 12 a 15 dias após a cv. Chasselas dorē, as cvs. Riesling itälico, Semillon, Trebbiano, Isabel e Bonarda; ao 49 grupo, ou seja, maturam de 25 a 30 dias após a cv. Chasselas doré, as cvs. Merlot, Barbera, Cabernet franc, Petit Syrah, Malvasia de Lipari e Moscatel branco.

A classificação de cultivares segundo a época de matu ração permite que se façam vinhedos com castas que apresentam ciclos ve getativos semelhantes, a fim de se facilitar as präticas culturais, bem como o escalonamento dos serviços de vinificação, uma vez que, sabendo-se a data média de maturação para as diferentes cultivares, é possível programar-se a sequência das cultivares a serem industrializadas (GOBBATO, 1940).

4.1.4. Inicio ao final da queda das folhas (IQF-FQF)

Na tabela 2 e na figura 1 são apresentadas as datas médias do início da queda das folhas, onde se observa uma diferença de 19 dias entre a data média do início da queda das folhas mais precoce em relação à mais tardia, e uma diferença de 25 dias entre o final da queda das folhas mais precoce em relação à mais tardia. A tabela 3 e a 
figura 2 mostram que o número de dias entre o inicio e o final da queda das folhas foi em mëdia de 78 dias, apresentando como valores extre mos a cv. Moscatel branco com 55 dias e a cv. Bonarda com 90 dias. VAS CONCELLOS (1930) encontrou como data média para a queda das folhas $01 /$ 3 para a cv. Isabe1, $26 / 2$ para a cv. Trebbiano e 16/3 para a cv. Malva sia. Segundo esse autor a antecipação na data da queda das folhas, pa ra Piracicaba, é causada pelo período de estiagem que normalmente ocor re no final do verão. GOBBATO (1940) considerou como data média para as cultivares Merlot, Trebbiano e Cabernet franc, 15/6, 16/6 e 06/6, respectivamente. BĀN (1979) considerou a data do início da queda da primeira folha e a data da queda da ültima folha como sendo 08/3 e 09/ 7 para a cv. Cabernet franc, 10/3 e 09/7 para a $\mathrm{cv}$. Isabel, 08/4 e $07 /$ 6 para a cv. Mérlot.

A maioria dos pesquisadores consideram a data do amarelecimento das folhas, isto $\bar{e}$, o processo gradativo e natural da que da das folhas (BRANAS et alii, 1946; ZULUAGA et alii, 1971; GALET , 1983). O fato que ocorre na MRH-311 é que, normalmente, após a colheita das uvas suspendem-se os tratamentos fitossanitärios e as plantas ficam sujeitas ao ataque dos fungos. Esses fungos causam a queda das folhas, não por elas estarem senescentes, mas sim pelos danos causados em sua folhagem. Talvez esta, tambēm, seja a razão pela qual um bom nú mero de gemas deixam de brotar, na primavera. As chuvas, os ventos e, principalmente, as geadas precoces aceleram a queda das folhas. 


\subsubsection{Subperiodos}

A tabela 5 representa o nümero de dias necessärios pa ra a realização dos vārios subperíodos da videira.

Início da brotação - início da floração (IB-IF): cons tatou-se uma diferença de 17 dias entre a cultivar que necessitou o me nor nümero de dias (41, cv. Isabe1) e a que necessitou o maior número de dias (58, cv. Bonarda).

GOBBATO (1940) encontrou valores semelhantes para as cultivares Merlot (45 dias) e Trebbiano (46 dias). ZULUAGA et alii (1971) dizem que, para a Argentina, os valores variam de 43 a 47 dias. Início da brotação - início da maturação (IB-IM) : ocorreu uma diferença de 13 dias entre a cultivar mais precoce, para a realização deste subperíodo (114, cv. Moscatel branco) e a mais tardia (127, cv. Bonarda).

Início da floração - início da maturação (IF-IM) : observou-se uma diferença de 17 dias entre a cultivar mais precoce (68, cvs. Merlot e Moscatel branco) e a mais tardia (85, cv. Isabel).

Início da brotação - final da maturação (IB-FM) : cons tatou-se uma diferença de 18 dias entre a cultivar que necessitou o me nor nümero de dias para a realização da colheita (162, cv. Riesling itälico) e a que necessitou o maior nümero de dias (180, cv. Isabe1).

Final da floração - final da maturação (FF-FM) : ocorreu uma diferença de 26 dias entre a cultivar mais precoce (91, cv. Riesling itálico) e a mais tardia (117, cv. Isabel). 
81.

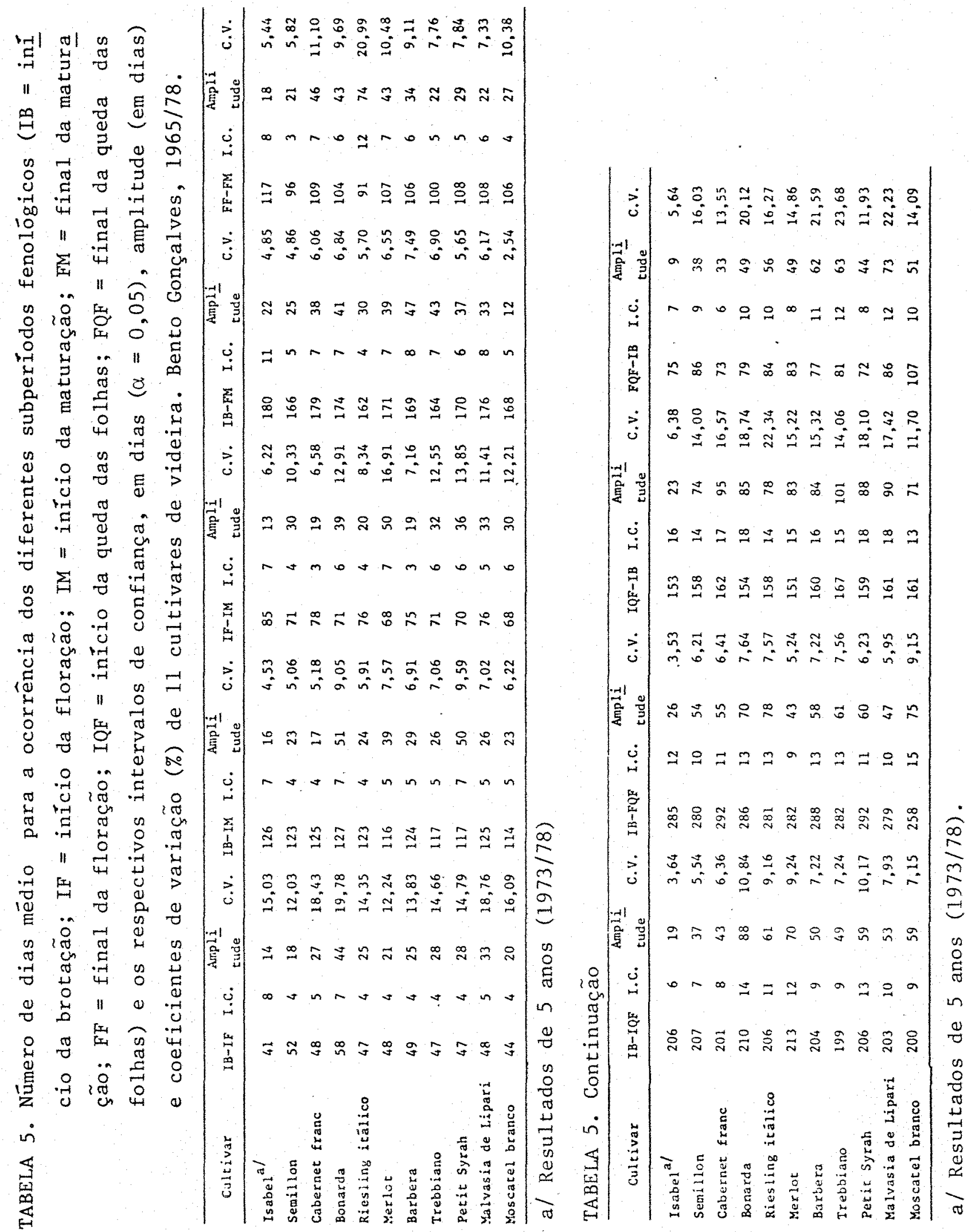


Início da brotação - início da queda dạs folhas (IB$-\mathrm{IQF})$ : observou-se uma diferença de 14 dias entre a cultivar mais precoce (199, cv. Trebbiano) e a mais tardia (213, cv. Merlot).

Início da brotação - final da queda das folhas

$-F Q F)$ : verificou-se que ocorreu uma diferença de 34 dias entre a culti var que realizou o ciclo vegetativo mais precoce (258, cv. Moscatel branco) em relação à mais tardia (292, cvs. Petit Syrah e Cabernet franc).

Início da queda das folhas - início da brotação (IQF$-I B)$ : constatou-se uma diferença de 16 dias entre a cultivar mais pre coce (151, cv. Merlot) e a mais tardia (167, cv. Trebbiano).

Final da queda das folhas - início da brotação (FQF-IB): corresponde ao nümero de dias em que as mudanças morfológicas deixam de ser visíveis. Constatou-se uma diferença de 35 dias entre a cultivar mais precoce (72, cv. Petit Syrah) e a mais tardia (107, cv. Moscatel branco).

A figura 9 representa o ciclo vegetativo médio para a viticultura na MRH311, no qual são apresentados os meses de ocorrência para os värios períodos pelos quais deve passar a videira, até completar um ciclo vegetativo. 


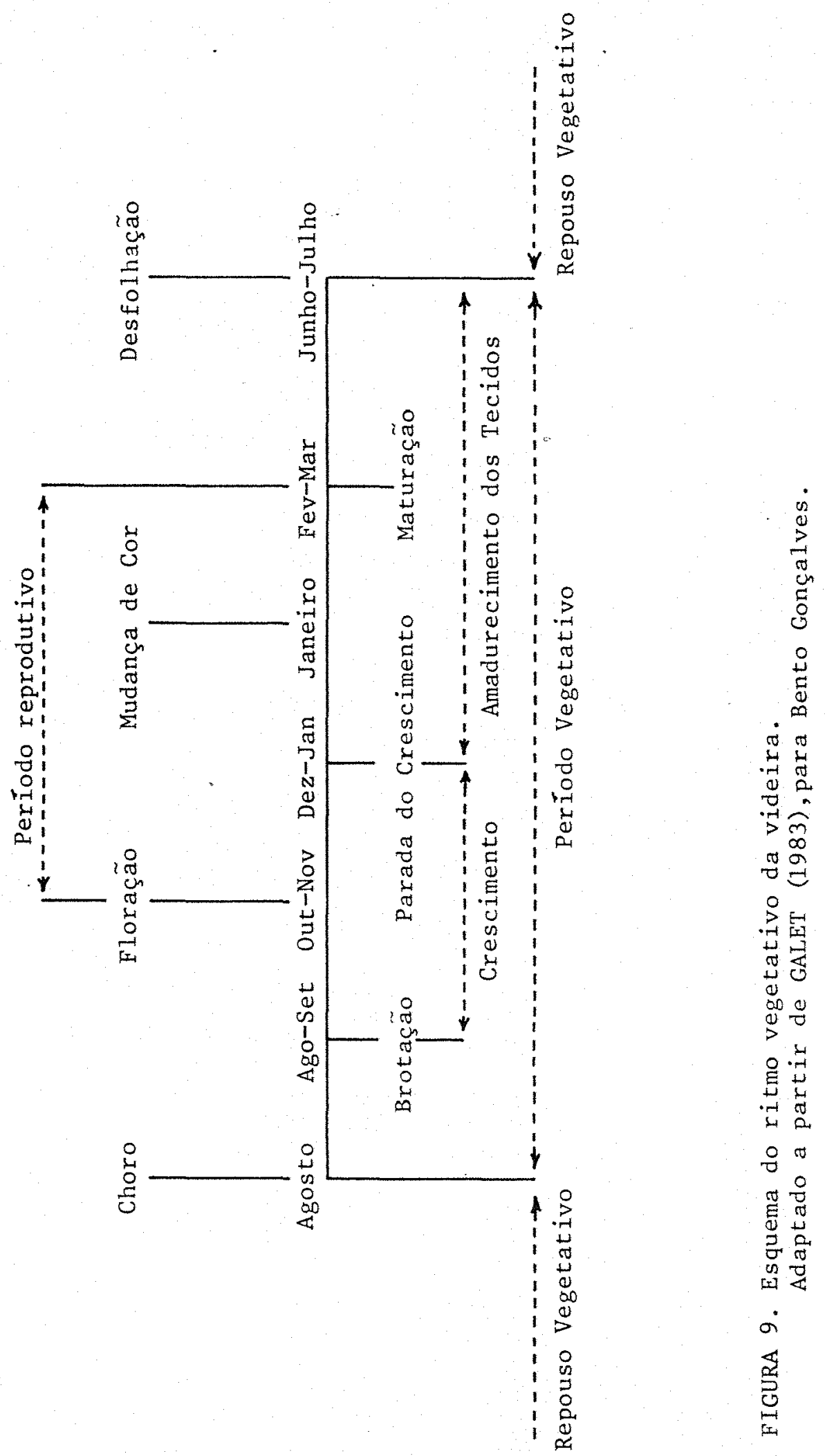




\subsubsection{Comparação fenolögica entre a cultivar Cabernet franc e as demais cultivares em estudo}

Tomou-se como referência a cv. Cabernet franc devido ao fato da mesma ser encontrada, praticamente, em toda a MRH311 face às boas produçôes e à qualidade dos vinhos elaborados a partir de suas uvas. Além disso, è entre as viníferas nobres, uma das mais resistentes às" doenças fúngicas, principalmente no que tange às podridões do cacho (EMBRAPA, 1983).

A tabela 6 representa o nümero de dias necessários pa ra as cultivares em estudo atingirem os diversos estádios fenológicos quando comparadas com a fenologia média da cultivar Cabernet franc. Os valores negativos $(-2$ correspondem ao nümero de dias anteriores à data média de sua ocorrência na cv. Cabernet franc e os valores positivos $(+)$, ao nümero de dias posteriores à data média de sua ocorrência na cv. Cabernet franc. Tomando-se, pois, a referida cultivar como referên cia e considerando-se as datas extremas para as värias fases, temos que a cv. Isabel iniciou a brotação 7 dias antes e terminou 9 dias antes, jā a cv. Moscatel branco iniciou a bretação 16 dias após e terminou 11 dias após. A cv. Isabel iniciou e terminou a floração 13 dias antes, enquanto a cv. Moscatel branco iniciou a floração 14 dias após e termi nou 8 dias após. A cv. Isabel iniciou a maturação 6 dias antes e a cv. Riesling itälico terminou a maturação 14 dias antes, enquanto a cv. Malvasia de Lipari iniciou a maturação 8 dias após e a cv. Moscatel branco terminou de maturar 7 dias após. 0 ịnício da queda das folhas 


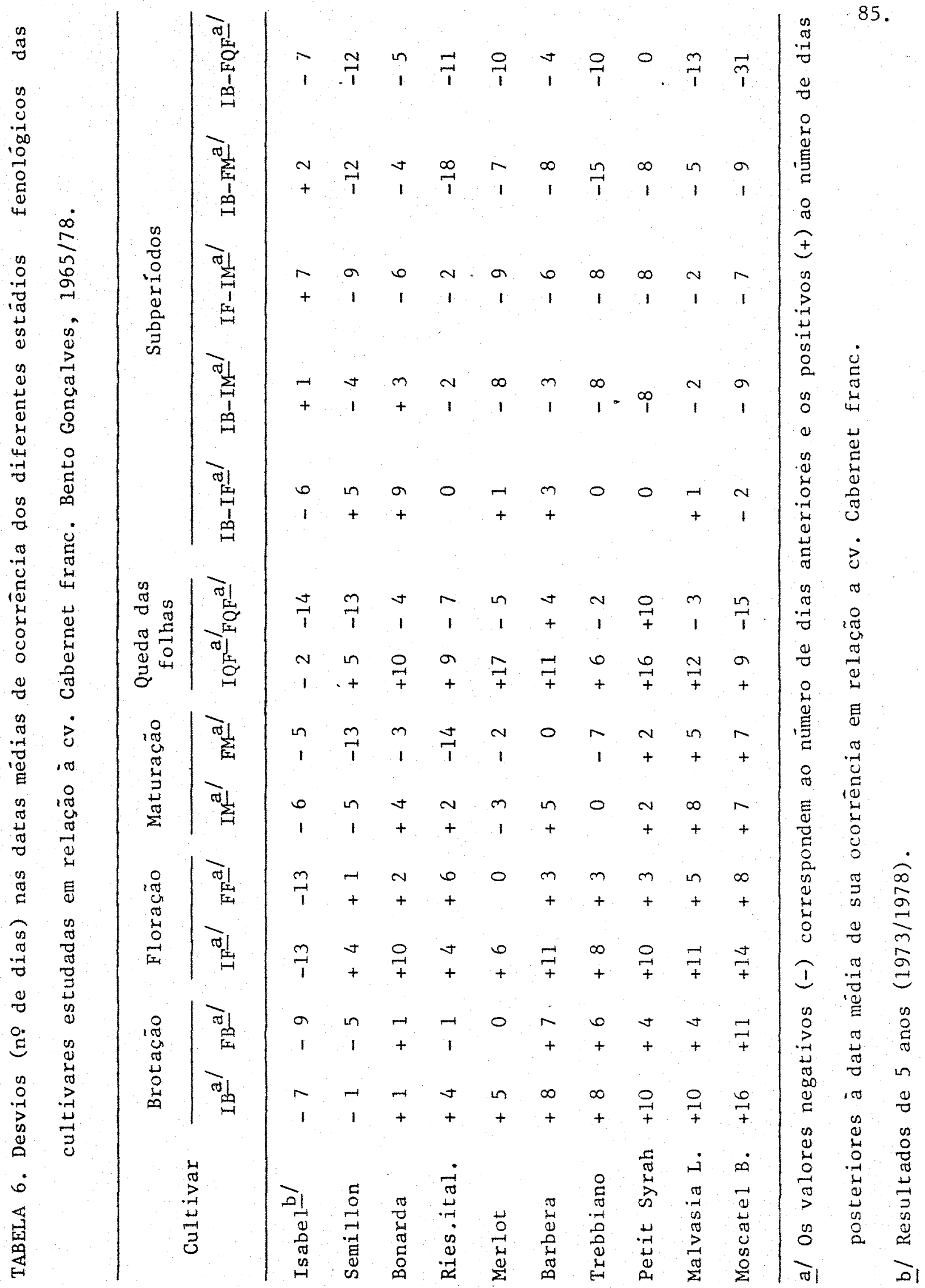


ocorreu 2 dias antes na $\mathrm{cv}$. Isabel e o término da queda das folhas foi 15 dias antes na cv. Moscatel branco; já a cv. Merlot iniciou a queda das folhas 17 dias após e a cv. Petit Syrah terminou de perder suas fo Thas 10 dias após. A comparação entre os subperíodos, tendo como referência a cv. Cabernet franc, mostrou que o subperíodo início da brota ção - início da floração ocorreu 6 dias antes para a cv. Isabel e 9 dias após para a cv. Bonarda. o subperíodo início da brotação - início da maturação ocorreu 9 dias antes para a cv. Moscatel branco e 3 dias a pós para a cv. Bonarda. O subperíodo início da floração - início da ma turação ocorreu 9 dias antes para as cvs. Semillon e Merlot e 7 dias a pós para a cv. Isabel. O subperíodo início da brotação - final da matü ração ocorreu 18 dias antes para a cv. Riesling itālico e 2 dias após para a cv. Isabel. Todas as cultivares, excetuando-se a cv. Petit Syrah, apresentaram para o subperíodo início da brotação - final da que da das folhas um tempo menor que a cv. Cabernet franc, sendo que a di ferença foi mais acentuada em relação à cv. Moscatel branco (31 dias).

\subsection{Caracterização tērmica}

\subsubsection{Temperatura-base}

A tabela 7 apresenta os graus-dia acumulados durante os treze anos, desde o início da brotação até a colheita, para a cv. Cabernet franc,e as respectivas regressões lineares simples, obtidas associando graus-dia com diferentes temperaturas-base. 


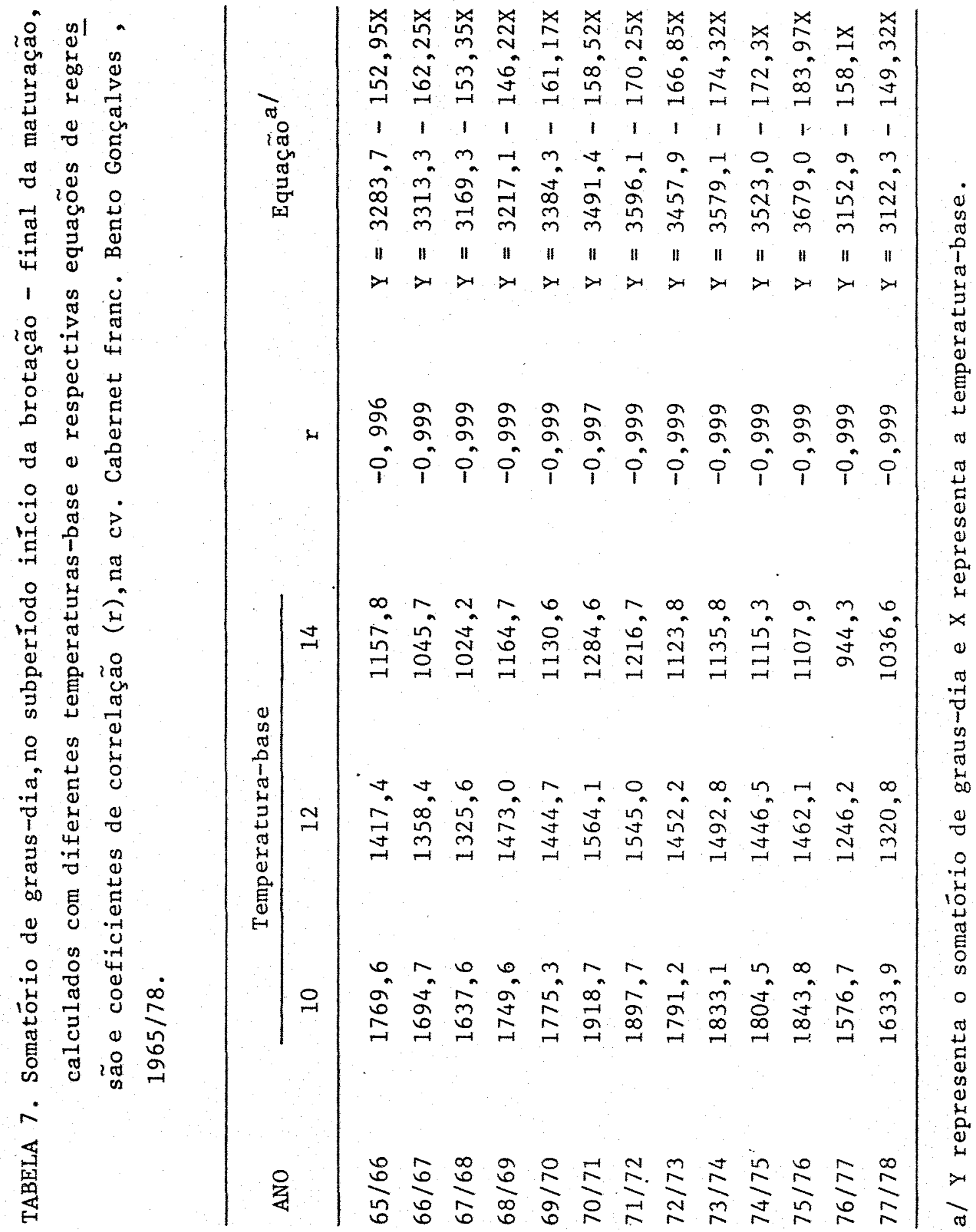


A figura 10a mostra as curvas traçadas a partir das regressões estimadas para as diversas temperaturas-base. Observa-se que não ocorreu uma aproximação entre elas em um único ponto e que a1 gumas delas se distanciaram das demais. A figura $10 \mathrm{~b}$ representa as cur vas que apresentaram uma tendência de se cruzarem em um ünico ponto. Procurou-se determinar o motivo para essa dispersão atravēs de uma anā lise entre a temperatura média e o nümero de dias necessārios para com pletar o subperíodo início da brotação-colheita (figura 11). Constatou-se que os três pontos mais afastados da reta corresponderam aos a nos agrícolas de $1967 / 68$ (temperatura média $20^{\circ} \mathrm{C}$ e ciclo de 158 dias que correspondeu a 25 dias a menos do que a mëdia); 1976/77 (temperatü ra média $18,1^{\circ} \mathrm{C}$, a menor de todos os anos e ciclo de 181 dias); $1977 /$ 78 (temperatura média $18,8^{\circ} \mathrm{C}$ e ciclo de 162 dias que correspondeu a 21 dias a menos do que a média). Como não foram analisados outros parâ metros que possivelmente influem na duração do ciclo vegetativo, tais como precipitação, insolação, época da poda seca, incidência de pragas e moléstias, entre outros, não foi possível explicar o motivo pelo qual esses três anos agrícolas $(1966 / 67,1970 / 71$ e 1971/72) não acompanharam a uniformidade de resposta evidenciada nos demais anos.

$\mathrm{Na}$ tabela 8 e na figura 12 são apresentadas as temperaturas- base escolhidas "a priori" (de 4 a $16^{\circ} \mathrm{C}$ ) e os respectivos des vios padrões das somas tērmicas (GD) expressos em dias, para a cultivar Cabernet franc, nos sete anos agrícolas selecionados. Os graus-dia corrigidos foram obtidos atravēs das equações contidas na tabela. 7 . 


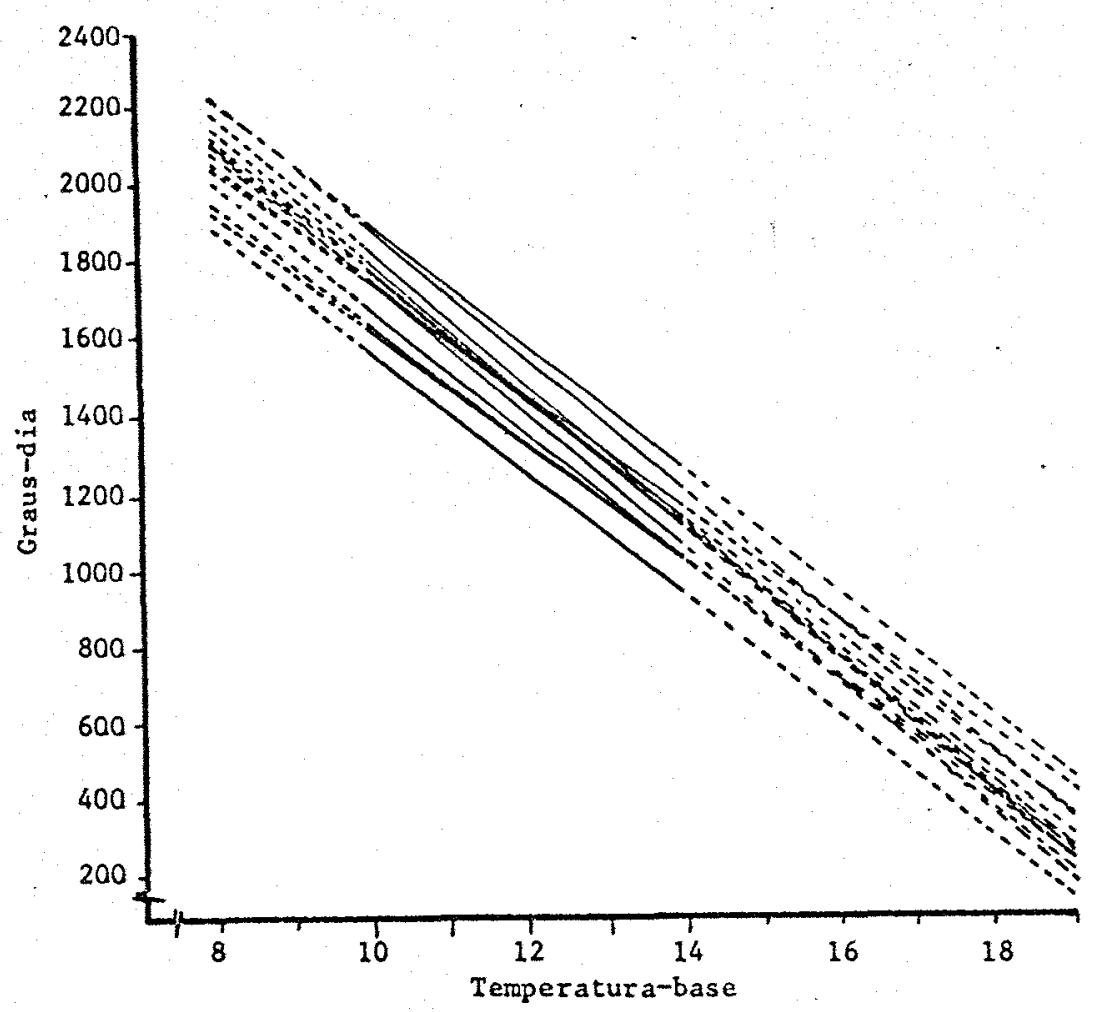

89.

Figura 10.a - Graus-dia acumulados obtidos em função da temperaturabase, no subperíodo início da brotação-final da matura ção, para a cultivar Cabernet franc. Bento Gonçalves, $1965 / 78$.

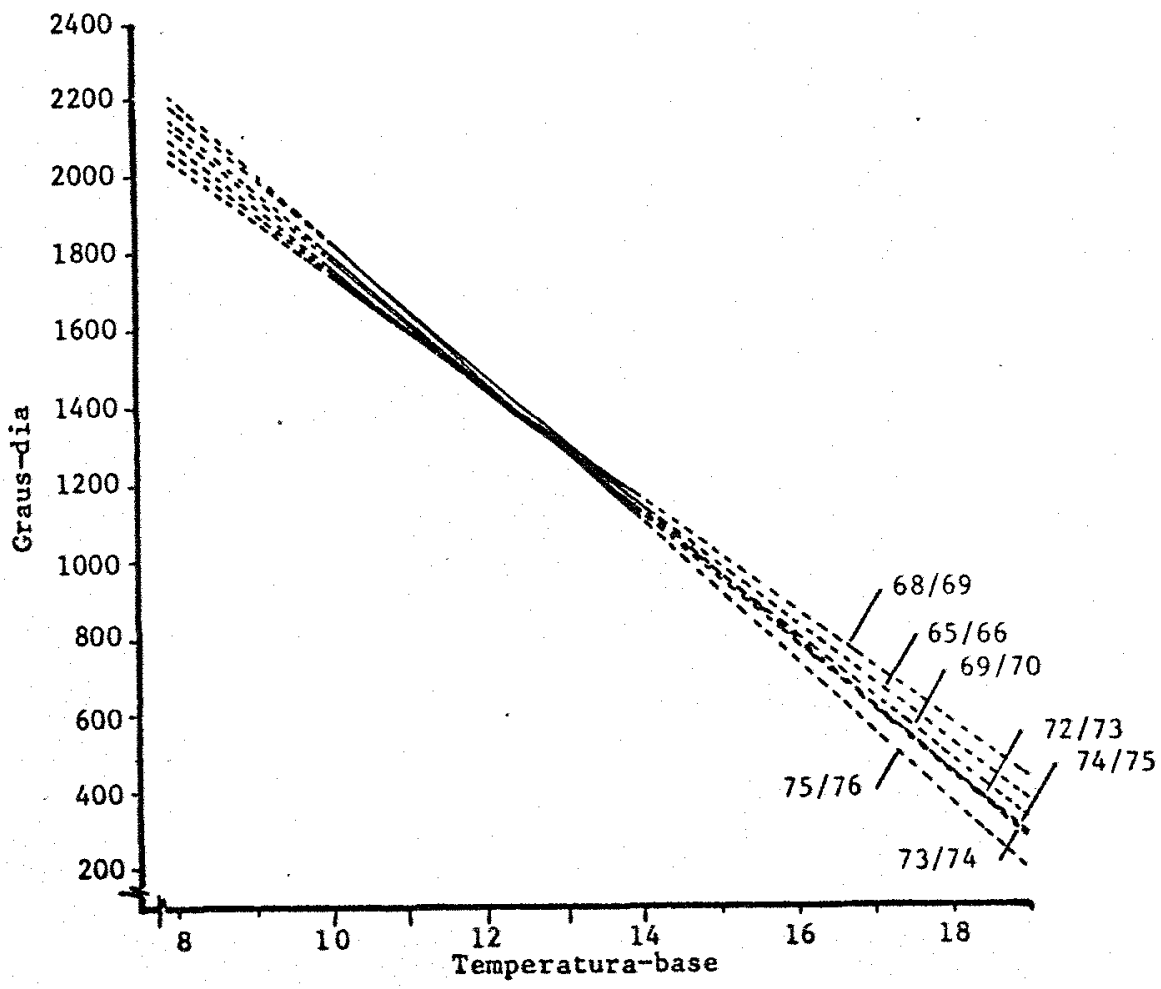

Figura 10.b - Graus-dia acumulados obtidos em função da temperaturabase, no subperíodo inicio da brotação-final da matura ção, para a cultivar Cabernet franc, nos sete anos agrícolas selecionados. 


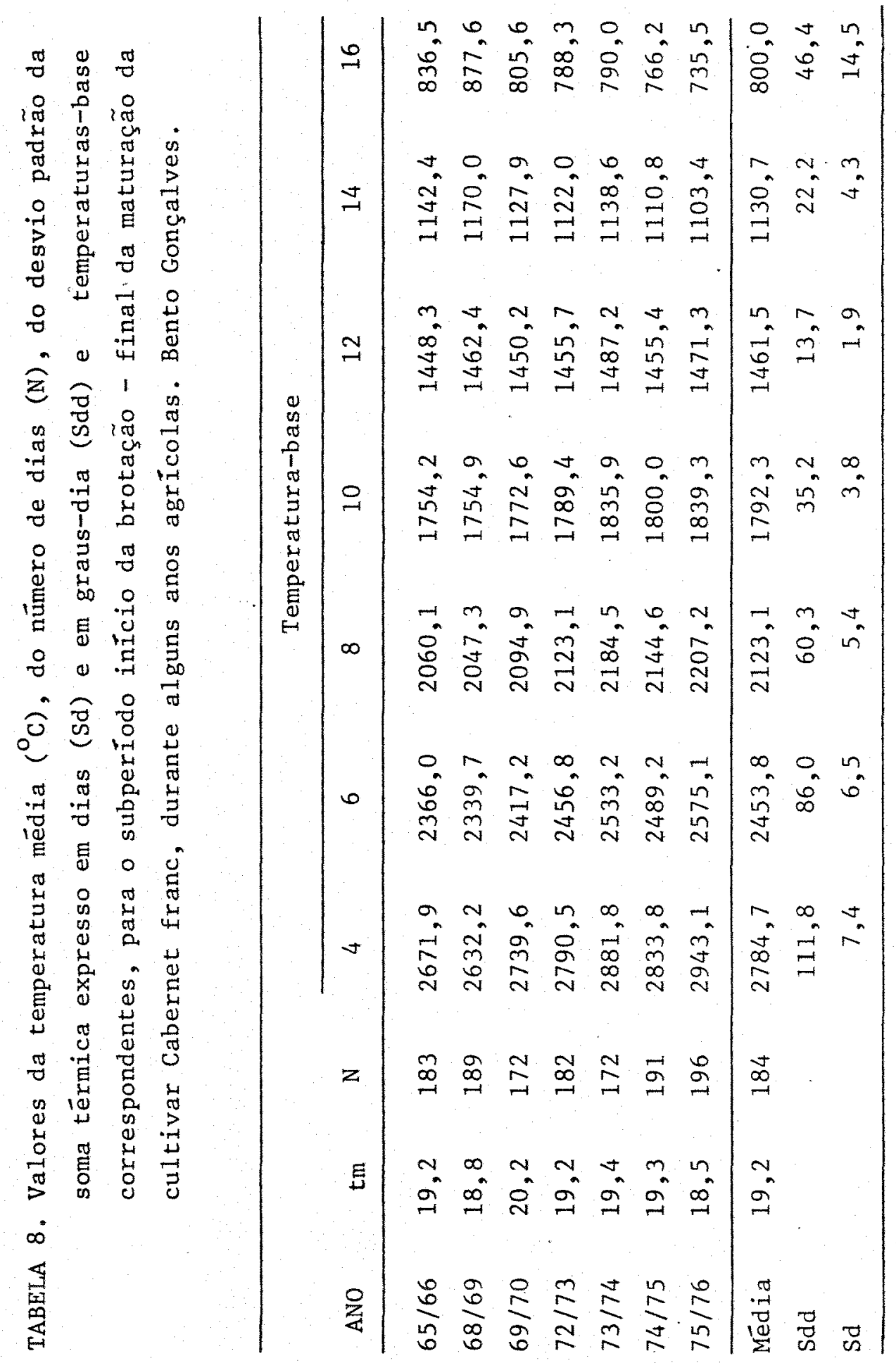




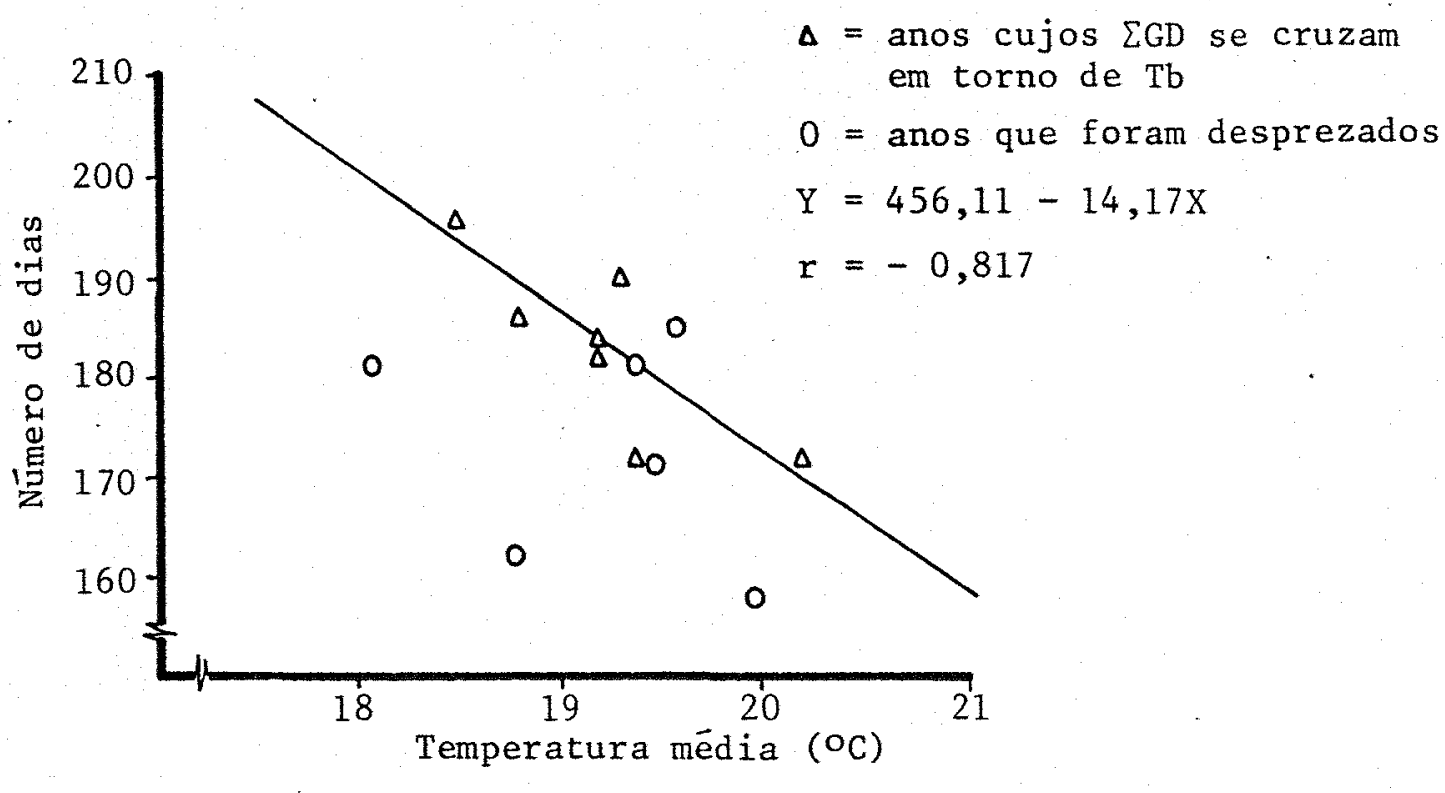

91.

Figura 11 - Número de dias necessārios para o subperíodo início da brotação - final da maturação da cultivar Cabernet franc em função da temperatura média do ar. Bento Gonçalves, $1965 / 78$.

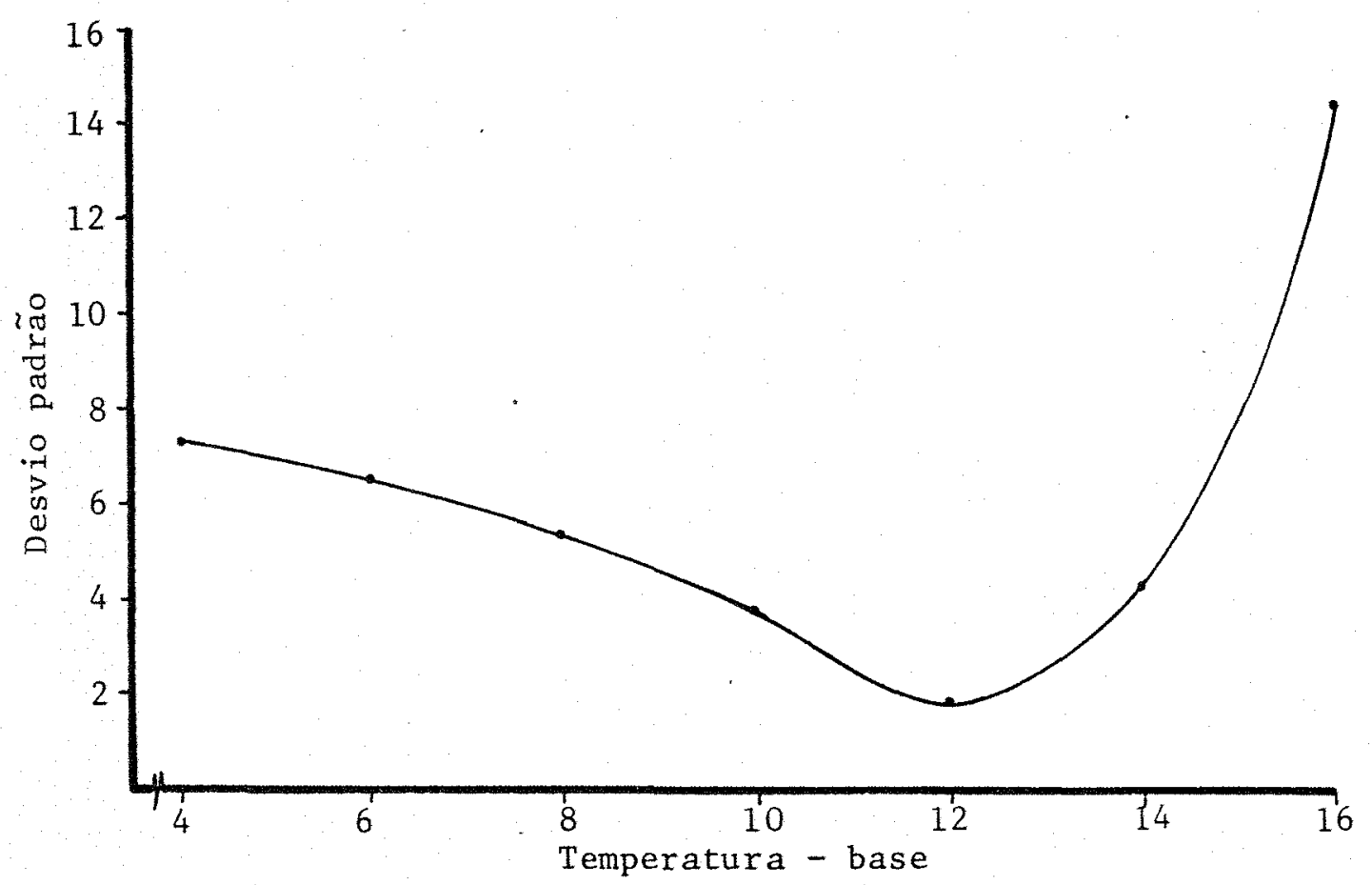

Figura 12 - Desvio padrão (em dias) em função de temperaturas-base entre 4 a $16^{\circ} \mathrm{C}$, para o subperíodo início da brotação final da maturação na cultivar Cabernet franc. Bento Gonçalves. 
Considerou-se que a temperatura-base que apresentou o menor valor do desvio padrão, em dias, representaria a temperatura-base. Assim sendo, $12^{\circ} \mathrm{C}$ foi a temperatura-base adotada para a cv. Cabernet franc. o mesmo procedimento adotado na determinação da temperatura-base para a cv. Cá bernet franc (duração do ciclo 179 dias, uma das mais tardias entre as estudadas) foi utilizado para a cv. Riesling itälico (duração do ciclo 162 dias, a mais precoce entre as estudadas). Nesta ültima a temperatu ra-base calculada foi de $11^{\circ} \mathrm{C}$. Considerou-se,para o presente estudo, que a temperatura de $12^{\circ} \mathrm{C}$ representaria a temperatura-base para todo $o$ ciclo vegetativo e para todas as cultivares estudadas.

Esse valor coincide com o obtido por ALMEIDA (1972) que, analisando as possibilidades vitícolas de Angola, testou as temperaturas-base de 10,12 e $14^{\circ} \mathrm{C}$ e constatou que a de $12^{\circ} \mathrm{C}$ era a que meThor se ajustava às necessidades térmicas exigidas pela videira. Segun do este autor, a temperatura de $10^{\circ} \mathrm{C}$ daria um acúmulo de calor efetivo inadequado pois excederia suas necessidades. Por outro lado, se fosse adotada a base $14^{\circ} \mathrm{C}$, as videiras não teriam possibilidades de maturar seus frutos, pois as necessidades térmicas ficariam aquëm de suas exigências. VLACHOS (1971) admite para a viticultura grega $11^{\circ} \mathrm{C}$. FREITAS e GRÁCIO (1971) consideraram que, para Portugal, ela oscila entre 12 e $13^{\circ} \mathrm{C}$, mas a grande maioria dos pesquisadores consideram que a temperatura-base para a videira $\vec{e} 10^{\circ} \mathrm{C}$ (BRANAS et alii, 1946; CONSTANTINESCU, 1967 ; HIDALGO, 1980).

Utilizando-se o método proposto por PoUGET (1967), foi determinado $\mathrm{T}^{\circ}$, que considera a média aritmética da soma das tempe- 
raturas médias dos dez dias anteriores à data da brotação. Na tabela 9 são apresentados os $\mathrm{TO}^{\circ}$ para as cultivares em estudo. Observando-se a data do início de brotação para cada cultivar, constata-se que não hou ve uma correspondencia entre a data do início da brotação e o $\mathrm{To}^{\circ}$, is to é, a cultivar que apresentou a data mais precoce para o início da brotação, na maioria das vezes, não apresentou o menor valor de $\mathrm{To}^{\circ}$. Em alguns anos as cultivares mais tardias foram as que apresentaram os me nores valores de $\mathrm{TO}^{\circ}$. Por este motivo a metodologia proposta por POUGET (1967) não foi empregada no presente estudo, apesar dos valores médios serem bastante próximos aos encontrados por ZULUAGA et alii (1971), para a Argentina $\left(14,5^{\circ} \mathrm{C}\right.$ para as cvs. Merlot, Trebbiano, Malva sia e Bonarda; $15^{\circ}$ para a cv. Cabernet franc).

\subsubsection{Graus-dia}

A tabela 10 apresenta a média, para os treze anos, do somatório dos graus-dia acumulados, nos estádios fenológicos brotação, floração, maturação e o total para o subperíodo início da brotação-fi nal da maturação. A cultivar que necessitou de menor soma térmica para atingir a maturação foi a Riesling itálico com 1299 GD, a de maior so ma foi a cv. Cabernet franc com $1427 \mathrm{GD}$.

Para atingir a maturação das uvas foram encontrados os seguintes valores na literatura: de menos de 1371,8 a mais de $2205^{\circ} \mathrm{C}$ pa ra a Califórnia, EEUU (WINKLER, 1965); 1500 a $1750^{\circ} \mathrm{C}$ para Israel (SA- 


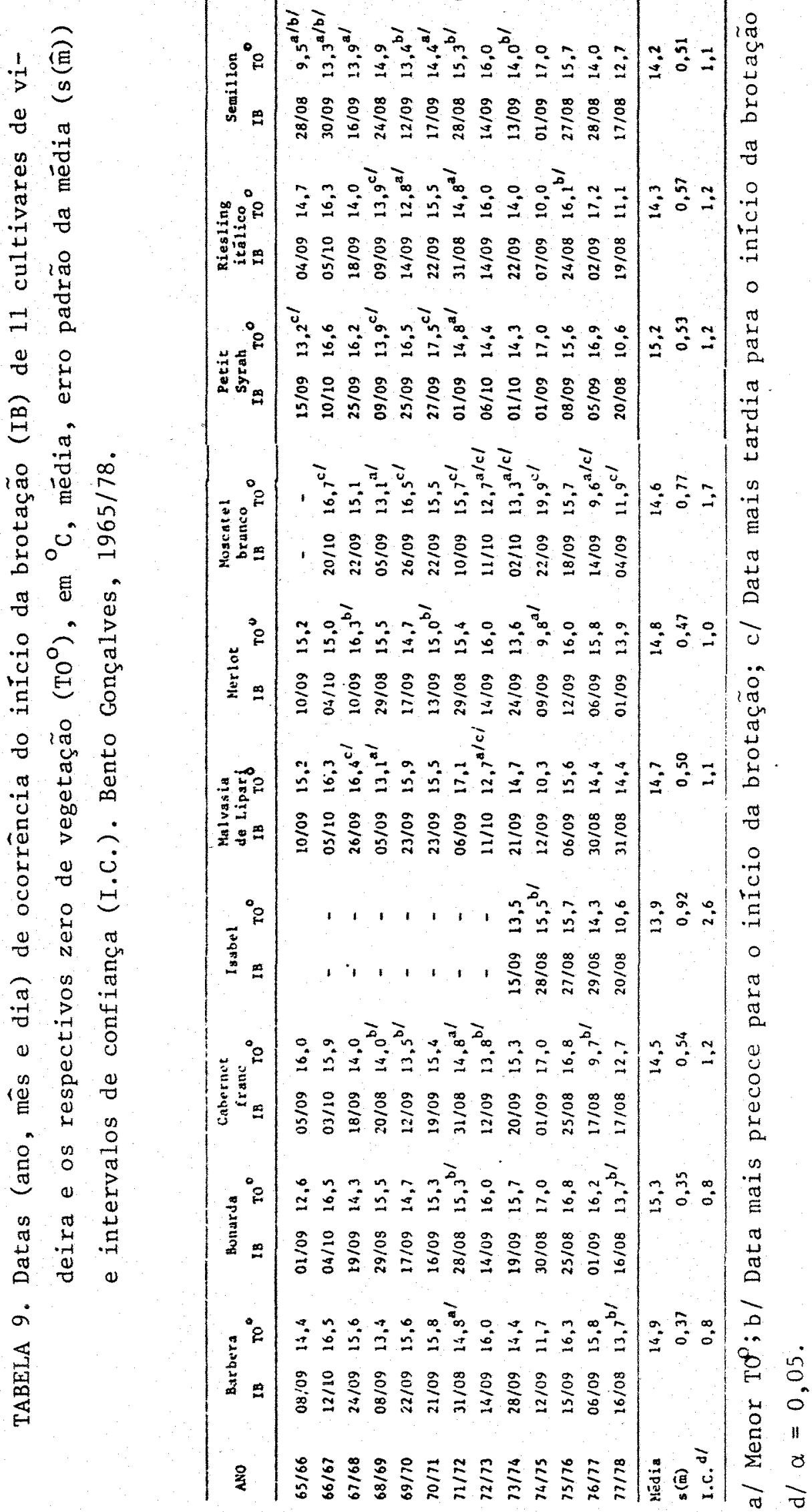


95.

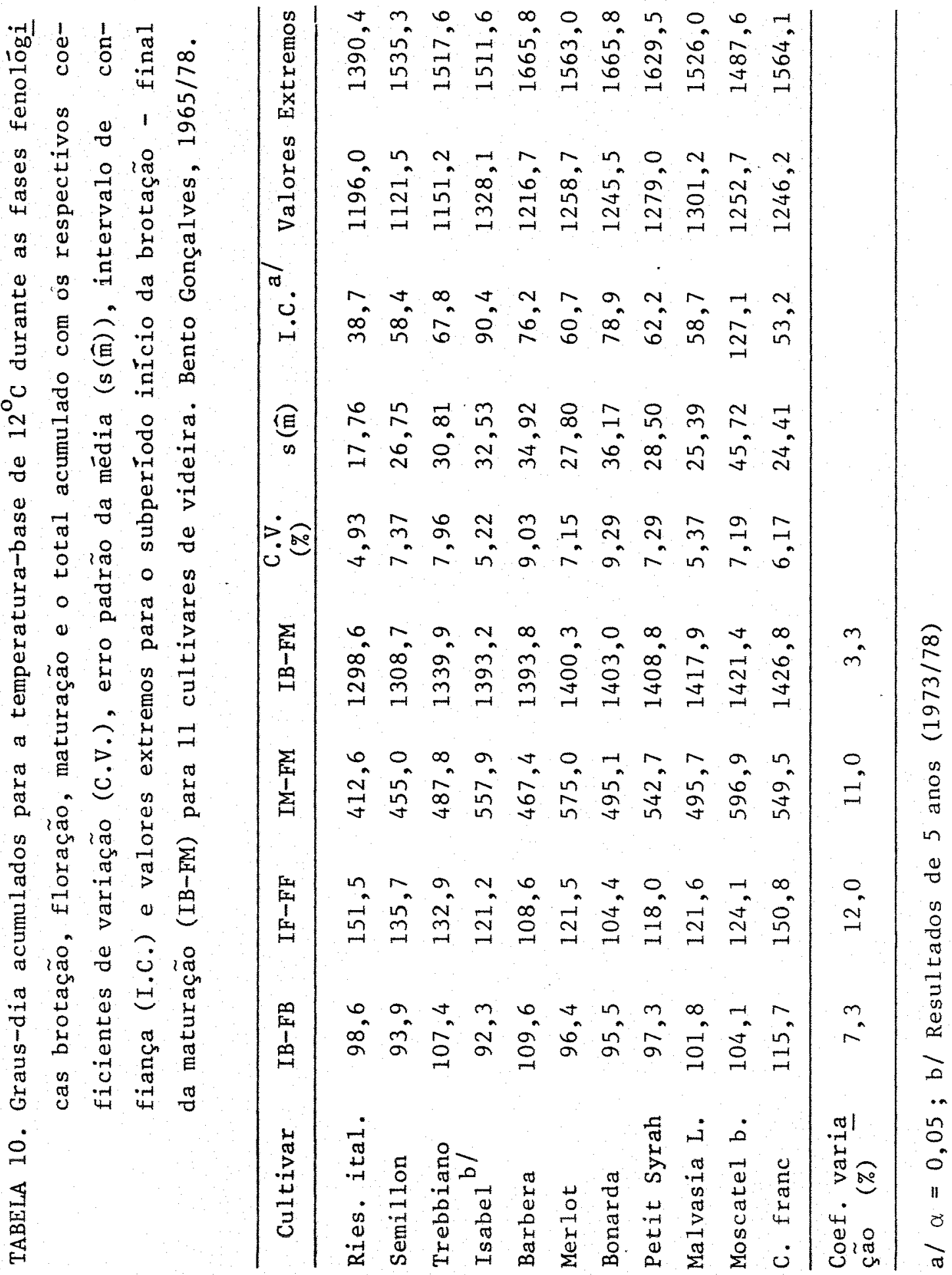


FRAN e HOCHBERG, 1971); 1400 a $1700^{\circ} \mathrm{C}$ para a Romenia (MARTIN, 1971); 970 a $1600^{\circ} \mathrm{C}$ para a Hungria (NEMETH, 1972); 1050 a $2100^{\circ} \mathrm{C}$ para a Bulgáa ria (STOEV et alii, 1971); 992 a $2142^{\circ} \mathrm{C}$ para a França (HUGLIN, 1971); $2197^{\circ} \mathrm{C}$, para Caldas, MG (ROSA FILHO, 1973); $921^{\circ} \mathrm{C}$ para as cultivares precoces e $1354^{\circ} \mathrm{C}$ para as cultivares tardias, para a Hungria (DUNKEL et alii, 1980).

Considerando-se todo o período vegetativo o valor mēdio seria $2350^{\circ} \mathrm{C}$. Para este período foram encontrados os seguintes va lores na literatura: de menos de 2500 a $3300^{\circ} \mathrm{C}$ para a Russia (Davitaya, 1948 citado por VERDEREVSKIY, 1962); $3200^{\circ} \mathrm{C}$ para a Austria (MUL LNER, 1971) ; de menos de 1500 a mais de $2900^{\circ} \mathrm{C}$ para o zoneamento da videira européia no Rio Grande do Sul (RIO GRANDE DO SUL, 1975); de me nos de 1300 a mais de $2300^{\circ} \mathrm{C}$ para o zoneamento da videira em Santa Ca tarina (EMPASC, 1978).

Observa-se que os valores médios encontrados estão em conformidade com aqueles encontrados para outras regiões vitícolas.

\subsubsection{Temperatura ativa}

A tabela 11 apresenta a média dos treze anos do somatório da temperatura ativa acumulada para os estádios fenológicos bro tação, floração, maturação e o total correspondente ao subperíodo ini cio da brotação - final da maturação. Observa-se que houve um comporta mento bastante semelhante entre todas as cultivares e para todos os es 


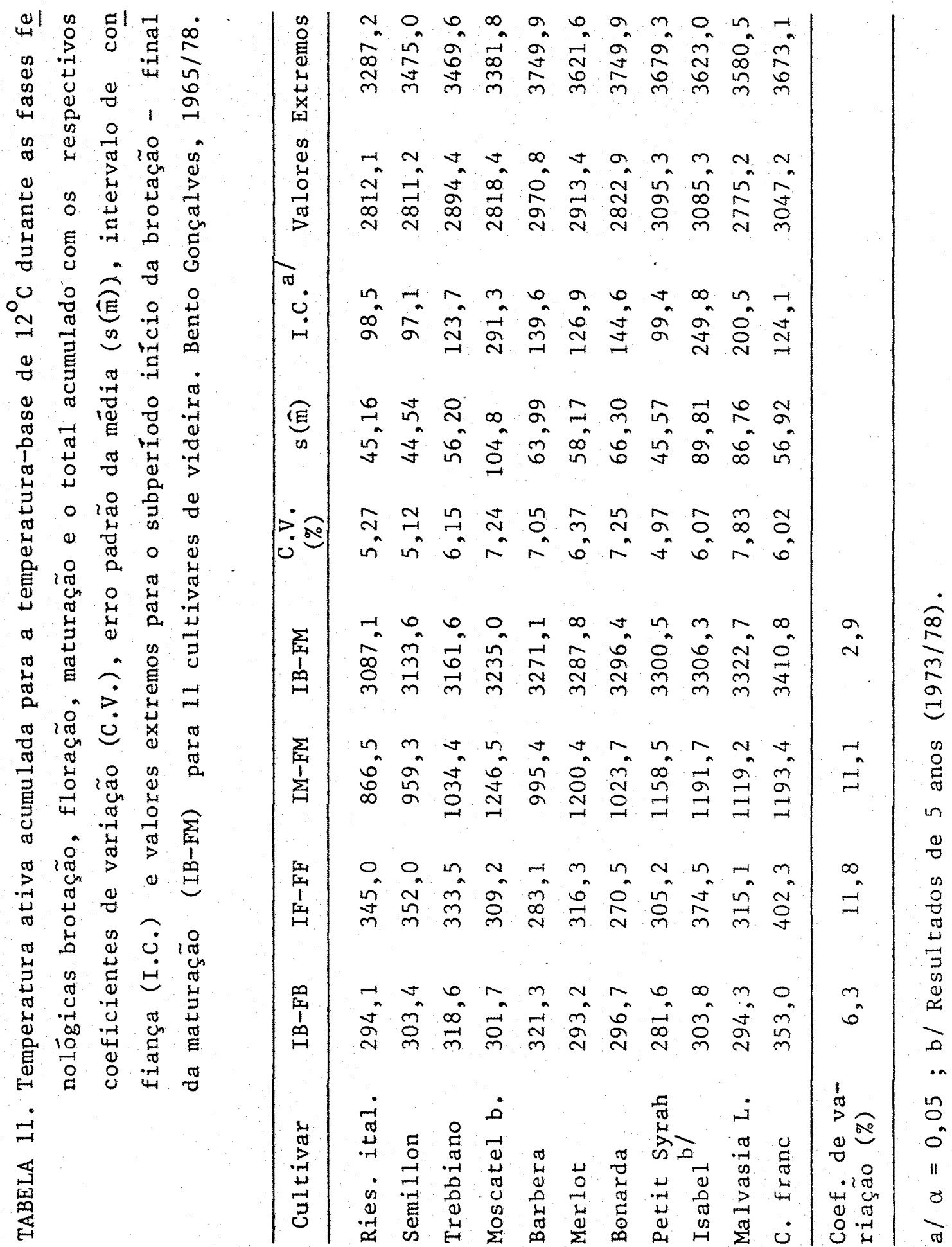


tädios fenológicos. A cultivar que necessitou de menor soma de tempera turas para atingir a maturação foi a Riesling itälico, com $3087^{\circ} \mathrm{C}$, e a de maior soma foi a $\mathrm{cv}$. Cabernet franc, com $3411^{\circ} \mathrm{C}$. VASCONCELLOS (1930) encontrou valores que oscilam entre 2286 a $4411^{\circ} \mathrm{C}$, para Piracicaba, sa lientando que nos anos em que ocorreram secas prolongadas, as videiras necessitaram de maiores somas térmicas. Para atingir a maturação das u vas foram encontrados os seguintes valores na literatura: $3124^{\circ} \mathrm{C}$ para a cv. Merlot e $2992^{\circ} \mathrm{C}$ para a cv. Trebbiano, para Caxias do Sul (GoBBATO, 1940); 2800 a $4000^{\circ} \mathrm{C}$ para a Espanha (Marcilla, 1954 citado por HI DALGO, 1980); 2726 a $3837^{\circ} \mathrm{C}$ para a França (BRANAS et alii, 1946); 1610 a $3778^{\circ} \mathrm{C}$ para a Romênia (CONSTANTINESCU, 1967); 2200 a $3100^{\circ} \mathrm{C}$ para a Russia (GOLODRIGA, 1971); 2500 a $3300^{\circ} \mathrm{C}$ para a Alemanha Federal (AICHE LE, 1971); 2531 a $3191^{\circ} \mathrm{C}$ para Luxemburgo (FABER, 1971); 2572 a $2934^{\circ} \mathrm{C}$ para a Tchecos lovaquia (VERES e VALACHOVIC, 1978).

Pela comparação dos resultados encontrados com os de outros locais, apesar destes utilizarem a temperatura-base de $10^{\circ} \mathrm{C}$, vê-se que o regime térmico da MRH 311 está contido dentro dos limites en contrados pela maioria dos países vitícolas.

Constata-se que, tanto para os graus-dia como para a temperatura ativa, as mesmas cultivares (Riesling itälico e Cabernet franc) apresentaram os valores extremos, demonstrando que o cälculo das necessidades térmicas por qualquer um desses métodos apresentou resultados semelhantes (o que diferiu foi a metodologia empregada para o 
seu cálculo). As tabelas 10 e 11 mostraram que os coeficientes de variações foram mais altos para os estädios fenológicos floração e maturação, seguidos pelo da brotação. Quando se abrange o subperíodo brota ção - maturação, os coeficientes de variação diminuem nos dois métodos. Os resultados confirmam que cada cultivar necessita de uma certa soma de temperaturas para completar seu ciclo; se um determinado está dio fenológico necessitou menor soma tërmica para ser completado, um outro necessitará de uma maior, dando como resultado final valores mais ou menos constantes.

A tabela 12 apresenta o número mëdio de dias e as respectivas necessidades térmicas para o subperíodo início da brotação ao final da maturação para todas as cultivares estudadas, excetuando-se a cv. Isabel, uma vez que sua fenologia foi determinada para um pe ríodo de 5 anos e não de 13 anos como nas demais. Observa-se, de um mo do geral, que as cultivares que necessitam de um menor número de dias para atingirem a maturação, apresentaram os menores valores do somatório térmico, seja para graus-dia ou temperatura ativa, enquanto que as cultivares que necessitam de um maior número de dias para atingirem a maturação apresentaram os maiores valores da soma térmica, exceção fei ta à cv. Moscatel branco. A cv. Moscatel branco foi a ültima, entre as cultivares estudadas, a iniciar a brotação, o que quer dizer que ela necessita de temperaturas mais elevadas para iniciar a brotação. Este fato pode explicar porque esta cultivar, que apresentou um subperíodo de alguns dias mais precoce, alcançou uma das maiores somas térmicas.. 
TABELA 12. Nümero de dias e valores mëdios do somatörio dos graus-dia $(\Sigma G D)$ e temperatura ativa ( $\Sigma \mathrm{Ta}$ ) para o subperíodo início da brotação - final da maturação (IB-FRi) de 10 cultivares de videira. Bento Gonçalves, 1965/78.

\begin{tabular}{lccc}
\hline \multicolumn{1}{c}{ Cultivar } & IB-FM & IGD & $\Sigma$ Ta \\
\hline Riesling itālico & 162 & 1298,6 & 3087,1 \\
Trebbiano & 164 & 1339,9 & 3161,6 \\
Semillon & 166 & 1308,7 & 3133,6 \\
Moscatel branco & 168 & 1421,4 & 3235,0 \\
Barbera & 169 & 1393,8 & 3271,1 \\
Petit Syrah & 170 & 1408,8 & 3300,5 \\
Merlot & 171 & 1400,3 & 3287,8 \\
Bonarda & 174 & 1403,0 & 3296,4 \\
Malvasia de Lipari & 176 & 1417,9 & 3322,7 \\
Cabernet franc & 179 & 1426,8 & 3410,8 \\
\hline
\end{tabular}


As cultivares estudadas apresentaram uma variação bastante pequena en tre o número de dias para atingirem o final da maturação (17 dias) e a presentaram, tambēm, como era de se esperar, uma diferença pequena en tre suas necessidades térmicas (128GD; $324^{\circ} \mathrm{C}$ para temperatura ativa).

\subsection{Produto heliotërmico}

A tabela 13 mostra a média dos treze anos do produto heliotérmico (P.H.) para os estádios fenológicos brotação, floração e ma turação,bem como o total requerido pelo subperíodo inicio da brotação-final da maturação. A cultivar que apresentou o menor P.H. para atingir a colheita foi a Riesling itälico, com 2,58, e o maior valor 3,17 pa ra a Cabernet franc. Foram encontrados na literatura os seguintes valo res de P.H.: de 2,8 a 4,5 para a França (BRANAS et alii, 1946); 3,225 pa ra a cv. Riesling itálico, 3,326 para a cv. Trebbiano, 1,98 para a cv. Merlot, 2,222 para a cv. Cabernet franc, 3,181 para a cv. Bonarda,para as uvas atingirem a maturação industrial, na Argentina (ZULUAGA et alii, 19.71); 2,29 a 3,7 para a Tchecoslováquia (VERES, 1971); 3,4 a 7,8 para Portugal (FREITAS e GRĀCIO, 1971); 2,5 a 4,07 para Luxemburgo (FABER, 1971); 2,7 a 3,6 para Israel (SAFRAN e HOCHBERG, 1971);2,2 a 2,8 para a Romênia (MARTIN, 1971).

Considerando-se o período da brotação ao amarelecimen to das folhas ( \pm 240 dias b foi encontrado P.H. próximo a 7,0 , concordando com o que foi proposto por WESTPHALEN (1977) para indicar a adap tação das cultivares européias ao clima do Rio Grande do Sul. ZULUAGA 
TABELA 13. Produto Heliotérmico (P.H.) durante as fases fenológicas brotação, floração, maturação e total acumulado com a res pectiva média, coeficiente de variação e erro padrão da mé dia para o subperíodo início da brotação - final da matura ção (IB-FM) para 11 cultivares de videira. Bento Gonçalves, $1965 / 78$.

\begin{tabular}{|c|c|c|c|c|}
\hline Cultivar & $I B-F B$ & $I F-F F$ & $I M-F M$ & $I B-F M$ \\
\hline Riesling itälico & 0,0251 & 0,0294 & 0,2106 & 2,5869 \\
\hline Semi11on & 0,0246 & 0,0346 & 0,2580 & 2,6661 \\
\hline Trebbiano & 0,0266 & 0,0303 & 0,3090 & 2,7125 \\
\hline Barbera & 0,0276 & 0,0221 & 0,2836 & 2,9107 \\
\hline Merlot & 0,0252 & 0,0268 & 0,4190 & 2,9276 \\
\hline Moscate1 branco & 0,0232 & 0,0311 & 0,3662 & 2,9325 \\
\hline Petit Syrah & 0,0216 & 0,0264 & 0,3766 & 2,9523 \\
\hline Bonarda & 0,0261 & 0,0195 & 0,3138 & 2,9576 \\
\hline Malvasia de Lipari & 0,0242 & 0,0322 & 0,3067 & 2,9955 \\
\hline 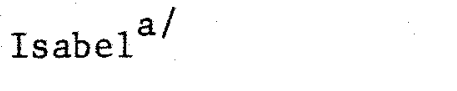 & 0,0242 & 0,0319 & 0,3906 & 3,0484 \\
\hline Cabernet franc & 0,0342 & 0,0437 & 0,3982 & 3,1715 \\
\hline Média & & & & 2,8965 \\
\hline Coef. variação & & & & 5,98 \\
\hline Erro padrão da mëdia & & & & 0,05 \\
\hline
\end{tabular}

a/ Resultados de 5 anos (1973/78). 
et alii (1971) consideraram que o limite, para a Argentina, deveria ser superior a 3,0 e inferior a 9,0. Observa-se que os valores encontrados para o subperíodo brotação - final da maturação mostraram-se estar den tro dos limites requeridos para a maturação da videira em outros paises.

\subsection{Coeficiente hidrotérmico para o desenvolvimento de fungos}

A tabela 14 apresenta o coeficiente hidrotérmico (C. H.) para alguns anos agrícolas selecionados em função de suas precipitaçôes. O ano agrícola $1969 / 70$ (o de menor precipitação para o subperíodo início da brotação - final da maturação com $496,8 \mathrm{~mm}$ ) foi o que apresentou a menor média, 59,51 e o ano agrícola 1972/73 (o de maior precipitação com $1335,7 \mathrm{~mm}$ ) apresentou a maior média, 143,32.

A probabilidade de ocorrência de doenças füngicas (míl dio) é determinada através do coeficiente hidrotérmico. Quando os valo res desse indice ultrapassam o valor considerado como limite, a possibilidade que a incidência dos fungos vão causar danos às videiras são bem maiores. Se esses valores forem inferiores ao limite, a probabilidade dos danos não terão maiores consequências. ZULUAGA et alii (1971) consideraram, para a Argentina, que o Iimite seria 40. RIO GRANDE DO SUL (1975) considerou, para o zoneamento da videira européia, que esse limite seria 50. WESTPHALEN (1977) propôs, para o Rio Grande do SuI., o valor 70. EMPASC (1978) considerou como limite o valor 100. Esses au 
104.

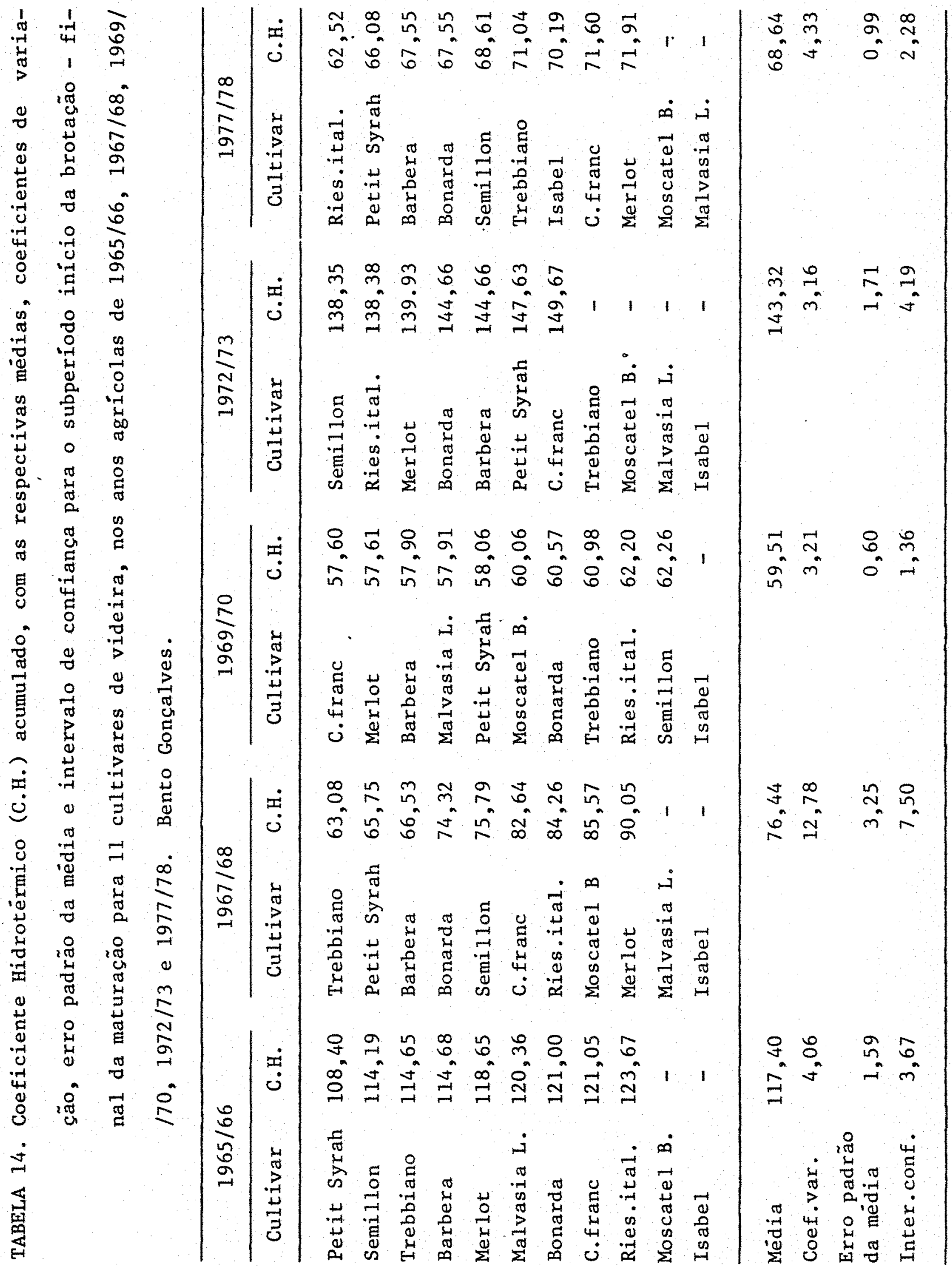


tores consideram que o período para o desenvolvimento dọ fungo vai de setembro a abril.

Os resultados mostraram que todos os anos excederam o limite proposto para o zoneamento da videira no Rio Grande do Sul e que somente no ano agrícola menos chuvoso (1969/70), para o subperíodo bro tação - final da maturação, encontraram-se valores que se aproximaram do limite proposto por WESTPHALEN (1977). Como, em média, a precipitação acumulada durante os meses de setembro a abril foi superior a $1000 \mathrm{~mm}, 0 \mathrm{~s}$ valores do coeficiente hidrotérmico serão superiores a 90 .

Os coeficientes hidrotērmicos determinados a partirda metodologia proposta por ZULUAGA et alii (1971) indicam que a probabilidade de ocorrência de doenças fúngicas, na videira européia cultivada na MRH311, pode ser considerada elevada mesmo quando selecionados os anos menos chuvosos da sërie estudada.

\subsection{Caracterização hel iohidrotērmica}

\subsubsection{Indice bioclimātico de Constantinescu}

A tabela 15 apresenta o indice bioclimätico (Ibc) para alguns anos agrícolas selecionados em função de sua precipitação. o ano agrícola de menor precipitação (1969/70, com 496,8mm) apresentou um Ibc médio de 4,95. 0 ano agrícola de maior precipitação (1972/73, com $1335,7 \mathrm{~mm}$ ) apresentou um Ibc de 1,50. Esses valores foram encontrados para os subperiodos início da brotação - final da maturação. 
106.

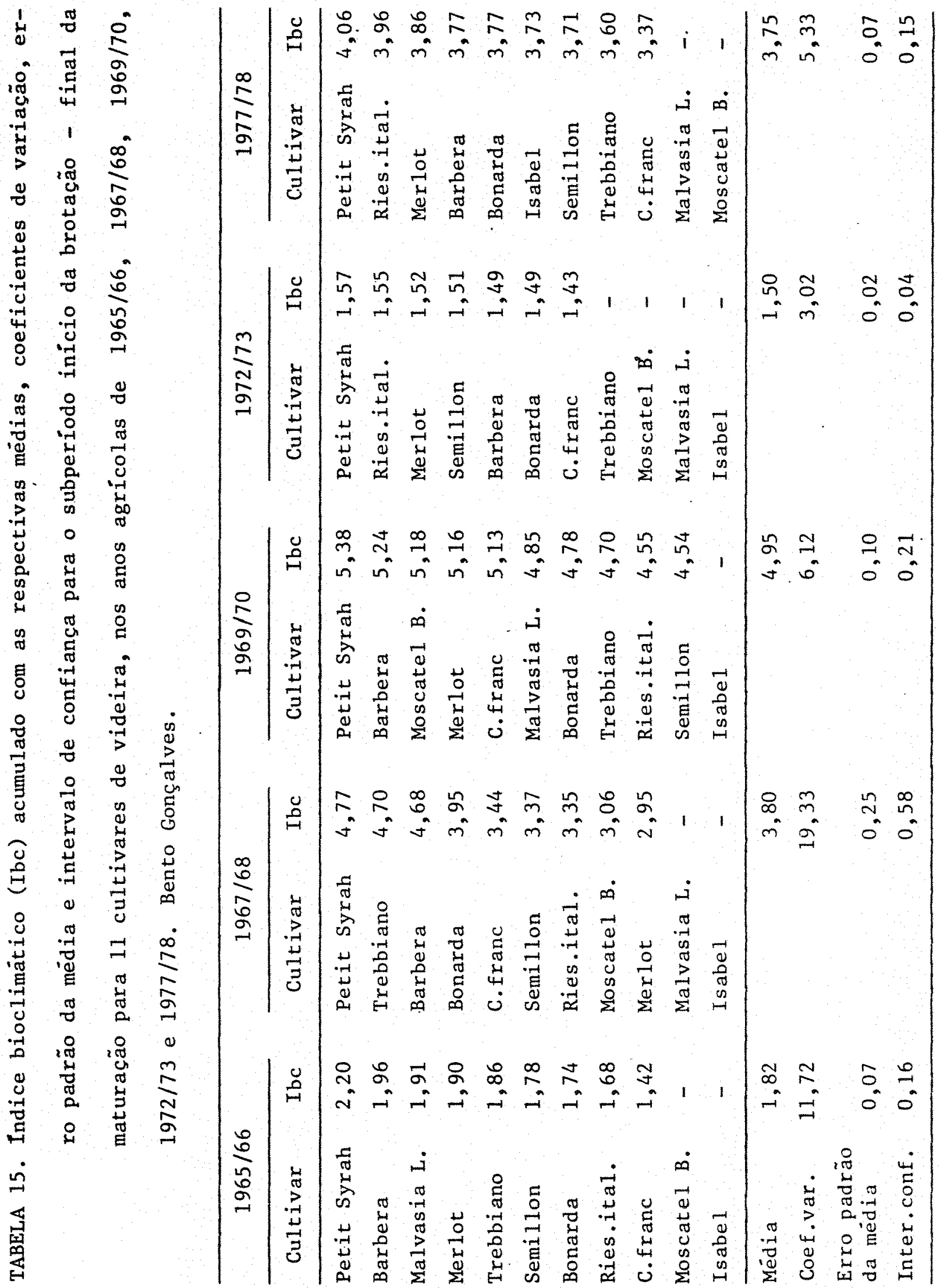


Para atingir a maturação das uvas foram encontrados, na literatura,os seguintes valores: de 3,0 (forte excedente hídrico) a 18,2 (défice acentuado) para a Romênia (CONSTANTINESCU, 1967); 15,2 pa ra as regiões portuguesas de Alvito, Cuba e Vidigueira (GRÁCIO, 1971); 6,05 a 8,23 para a Tchecosloväquia (VERES, 1971); 3,34 a 10,65 para a Iuguslávia (AVRAMOV et alii, 1971). Os baixos valores encontrados neste trabalho, mesmo nos anos menos chuvosos põem em evidência que a re gião apresenta uma precipitação excessiva quando comparada com outras regiões vitícolas.

\subsubsection{Quociente heliopluviométrico de maturação}

A tabela 16 apresenta o quociente heliopluviométrico de maturação (Q.M.), o qual caracteriza as condições de maturação das uvas no subperíodo início da mudança de cor das bagas ao final da matu ração.

0 ano.agrícola que apresentou o maior indice foi o de $1977 / 78$, com um valor médio de 3,92 , e o menor foi para o ano agrícola 1972/73, com 0,73. Os valores médios da insolação e da precipitação pa ra os anos agrícolas selecionados foram respectivamente 1977/78, com $398,5 \mathrm{hs}$ e $118,58 \mathrm{~mm} ; 1967 / 68$, com $272,4 \mathrm{hs}$ e $78,6 \mathrm{~mm} ; 1969 / 79$, com $351,7 \mathrm{hs}$ e $148,1 \mathrm{~mm} ; 1965 / 66$, com $300,5 \mathrm{hs}$ e $352,4 \mathrm{~mm} ; 1972 / 73$, com $302,3 \mathrm{hs}$ e $447,9 \mathrm{~mm}$.

WESTPHALEN (1977) considera que, quando o Q.M. for superior a 2,0 , as condições para a maturação das uvas serão favorecidas 
108.

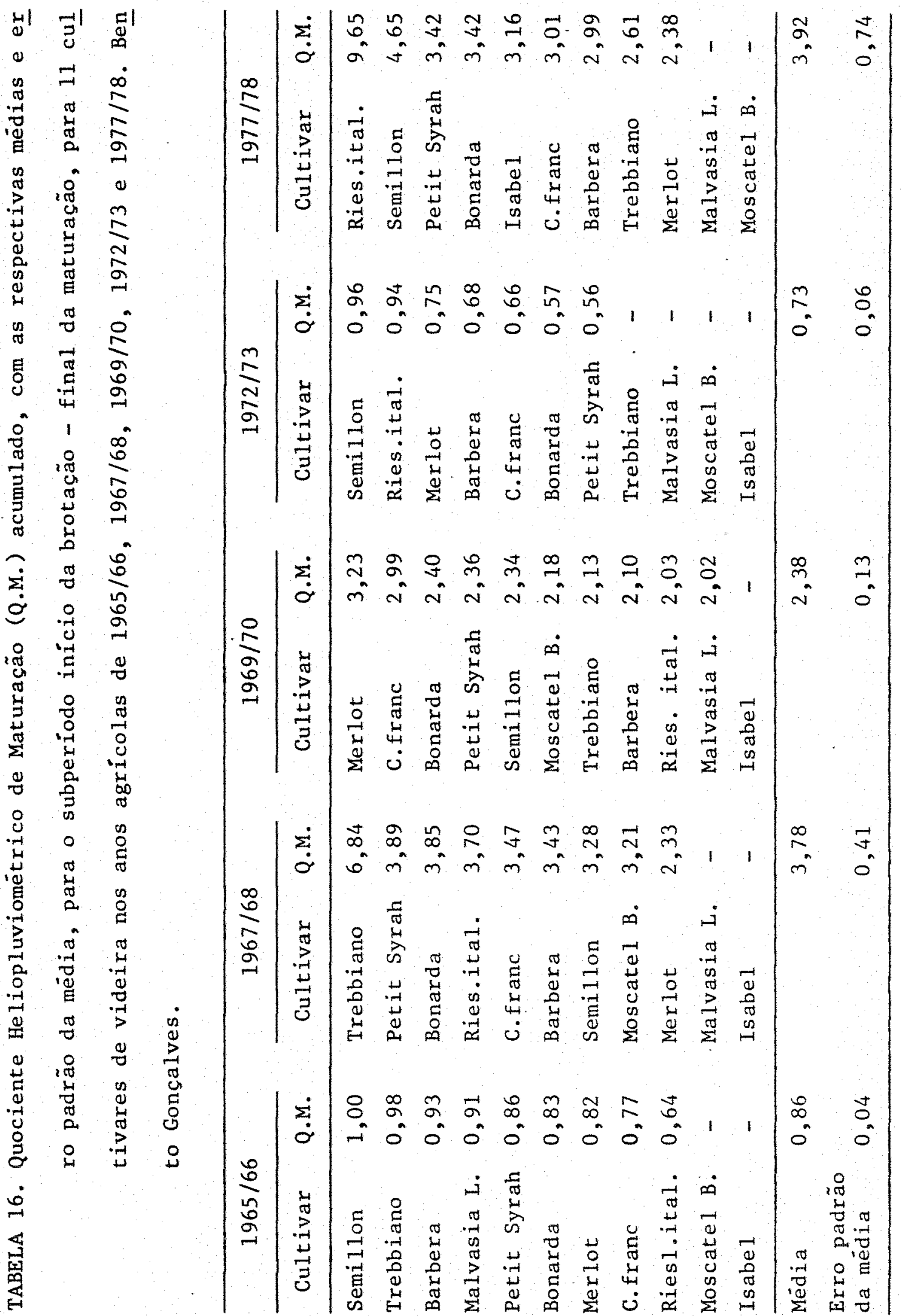


e as possibilidades de se obter um produto de melhor qualidade serão maiores. O zoneamento agroclimätico para a cultura da videira no Rio Grande do Sul utilizou o Q.M. para as cultivares de origem americana. Estas cultivares são bem mais resistentes às adversidades climáticas que as de origem européia. Sendo assim, seria mais lógico considerar o Q.M. tambēm para as cultivares européias, como comenta WESTPHALEN (1980), uma vez que estas, geneticamente, têm a capacidade de proporcio nar produtos de melhor qualidade, quando as condições climátiças forem favoráveis.

Comparando-se os resultados obtidos com os propostos por WESTPHALEN (1977), constata-se que os anos agrícolas de 1967/68, 1969/70 e 1977/78 apresentaram valores superiores a 2,0, Iimite mínimo estabelecido pelo autor para que haja uma maturação satisfatōria das $\underline{u}$ vas. Isto indica que os anos agrícolas citados foram favoráveis à matu ração das uvas e consequentemente apresentaram maiores possibilidades para a obtenção de um produto de melhor qualidade. Por outro lado, os anos agrícolas de 1965/66 e $1972 / 73$ não foram favoráveis, uma vez que apresentaram valores inferiores a 2,0 . 


\section{CONCLUSÕES}

Os resultados apresentados permitiram chegar às seguin tes conclusões:

- As cultivares Isabel e Semillon tiveram brotação mais precoce, a cultivar Moscatel branco mais tardia, sendo intermediäria nas cultivares Cabernet franc, Bonarda, Riesling itälico, Merlot, Barbera, Trebbiano, Petit Syrah e Malvasia de Lipari. Entre as médias ex tremas de brotação, foi observada uma amplitude de 23 dias.

- Quanto à ocorréncia da floração, a sequência das datas mëdias para cada cultivar foi semelhante à da brotação, observando-se uma amplitude de 27 dias entre as extremas.

- Segundo a escala de Pulliat, quanto à maturação, as cvs. Riesling itälico, Semillon, Trebbiano, Isabel e Bonarda demonstra ram pertencer ao 39 grupo (maturação de 12 a 15 dias apōs a Chasselas dorē), enquanto as cvs. Merlot, Barbera, Cabernet franc, Petit Syrah, Malvasia de Lipari e Moscatel branco demonstraram pertencer ao 49 gru- 
po (maturação de 25 a 30 dias apōs a Chasselas dorë). Entre as médias extremas de maturação, foi observada uma amplitude de 21 dias.

- Numa escala de maturação, a soma térmica média (graus-dia - GD) necessária para cada cultivar foi: Riesling itálico 1299GD, Semi11on 1309GD, Trebbiano 1340GD, Isabe1 1393GD, Barbera 1394GD, Merlot 1400GD, Bonarda 1403GD, Petit Syrah 1409GD, Malvasia de Lipari 1418GD, Moscate1 branco 1421GD e Cabernet franc $1427 \mathrm{GD}$.

- o somatório térmico médio obtido através da temperatura ativa mostrou que, para atingir a maturação das uvas, as cultivares necessitaram de: Riesling itälico $3087^{\circ} \mathrm{C}$, Semillon $3134^{\circ} \mathrm{C}$, Trebbiano $3162^{\circ} \mathrm{C}$, Moscatel branco $3235^{\circ} \mathrm{C}$, Barbera $3271^{\circ} \mathrm{C}$, Merlot $3288^{\circ} \mathrm{C}$, Bonarda $3296^{\circ} \mathrm{C}$, Petit Syrah $3300^{\circ} \mathrm{C}$, Isabel $3306^{\circ} \mathrm{C}$, Malvasia de Lipari $3323^{\circ} \mathrm{C}$ e a Cabernet franc $3411^{\circ} \mathrm{C}$.

- A cultivar Riesling itālico apresentou o menor somatório de produto heliotērmico (P.H.), atē a maturação das uvas $(2,59)$, enquanto a cultivar Cabernet franc apresentou o maior valor $(3,17)$.

- Os somatörios das necessidades térmicas e heliotérmicas mëdias, quando comparados com outras regiões viticolas, mostraram que a região apresentou condições térmicas e heliotérmicas suficientes para o desenvolvimento da videira.

- o coeficiente hidrotérmico (C.H.) e o indice bioclimätico (Ibc) mostraram que a região apresentou umidade excessiva em todos os anos estudados, considerando que os valores calculados excederam os limites minimos estabelecidos para outras regiões vitícolas. 
- Embora seja considerada excessiva a umidade para todo o ciclo, o quociente heliopluviométrico de maturação (Q.M.) demonstrou que, para alguns anos, existiram condições para a obtenção de uvas de boa qualidade para a vinificação. 


\section{LITERATURA CITADA}

AICHELE, H., 1971. Caractéristiques bioclimatiques des cépages et des vignobles - Allemagne. In: XIII Congres International de la Vigne et du Vin. Anais. Mendoza, Office International de la Vigne et du Vin, 1: $2-6$.

ALMEIDA, J.L.F. de, 1972. Possibilidades de produção de uvas de mesa em Moçâmedes e em Roçadas. Angola, Instituto de Investigação Agronômica de Angola. $19 \mathrm{p}$.

ALMEIDA, J.L.F. de e A.M. GRĀCIO, 1969. Macrozonagem da uva de mesa em Portuga1 Continental. De Vinea et Vino Portugaliae. Lisboa, $\underline{4}$ : $1-68$.

ARNOLD, C.Y., 1959. The determination and significance of the base temperature in a Linear Heat Unit System. Proc. American Society for Horticultural Science. Virginia, 74: 430-445. 
AVRAMOV, L., L. HRCEK e S. STANOJEVIC, 1971. Caractéristiques bioclimatiques des cépages et des vignobles - Yougoslavie. In: XIII Congres International de 1 a Vigne et du Vin. Anais. Mendoza, Office International de la Vigne et du Vin, 1: 2-12.

AZZI, G., 1959. Ecología agräria. Barcelona, Salvat Editores S. A. $449 \mathrm{p}$.

BĀN, A.D., 1979. Estudo ampelogräfico das principais cultivares do Estado do Rio Grande do Sul. Porto Alegre, IPAGRo. 166 p. (Série Boletim Técnico, 5).

BECKER, N.Y., 1978. Critēres écologiques de la délimitation des vigno bles septentrionaux. Bulletin de l'Office International de la Vigne et du Vin. Paris, 51: 179-183.

Berlato, M., V. SUTIl e A.0. CASTro, 1974. Comparação de 3 métodos de cälculo das exigências térmicas para o espigamento do milho. Agronomia Sulriograndense. Porto Alegre, 10: 87-94.

BRANAS, J., 1974. Viticulture. Montpellier, Dēhan, 990 p.

BRANAS, J., G. BERNON e L. LEVADOUX, 1946. Elëmënts de viticulture générale. Montpellier. Delmas Bordeaux, $400 \mathrm{p}$.

BRAVO, P. e D. de OLIVEIRA, 1974. Viticultura moderna. 4. ed. Coimbra, Liv. Almedina Editora. $463 \mathrm{p}$.

BUTTROSE, M.S., 1974. Climatic factors and fruitfulness in grapevines. Horticultural Abstracts. Maidstone, 44:319-326. 
CALO, A., 1972. Influenza di alcune condizioni ambientali sulla allegagione nella Vitis vinifera L. Rivista di Viticoltura e di Enologia. Conegliano, $\underline{5}$.

CALÓ, A. e A. Costacurta, 1974. Sulla reazione delle varietà delle specie Vitis vinifera L. ad alcuni fattori ambientali. In: Institu to Sperimentale per la Viticoltura. Anais. Conegliano, 31: 1-12.

CALó, A., A. COSTACURTA e G. NICOLin, 1976. Indagini sul ruolo della temperatura e sul comportamento di alcune varietá di vite (V. vinifera L.) in relazione al momento del germogliamento. Rivista di Viticoltura e di Enologia. Coneg1iano, 29: 135-147.

CALŌ, A., A. COSTACURTA, C.S. LIUNI, S. SPADA e G. ONDRADU, 1979. La fenologia della vite in Sardegna influenza delle forme di allevamen to vitigni e portinnesti. In: Instituto Sperimentale per la Viticol tura. Anais. Conegliano, 36: 1-9.

CARBONNEAU, A., 1982. Rapport de mission de viticulture en Rio Grande du Sud - Bresil. Bento Gonçalves, UEPAE/BG. 12 p.

CHANDLER, W.H., 1954. .Cold resistance in horticultural plants; a review. Proceedings of the American Society for Horticultural Science. New York, 64: 552-569.

CONSTANTINESCU, G., 1967. Mëthodes et principes de dëtermination des aptitudes viticoles d'une région et du choix des cépages appropriés. Bulletin de 1 'office International de 1 a Vigne et du Vin. Paris, 40: $1179-1205$. 
CONSTANTINESCU, G., 1971. Caractëristiques bioclimatiques des cépages et des vignobles-Roumanie. In: XIII Congres International de la Vig ne et du Vin. Anais. Mendoza, Office International de la Vigne et du Vin, 1: 2-42.

COSTACURTA, A. e G. ROSELLI, 1980. Fattori climatici ed edafici che condizionano gli impianti dei vigneti. Rivista di Viticoltura e di Enologia. Conegliano, 10: 469-480.

De FINA, A.L. e A.C. RAVELo, 1973. Fenologia. In: De FINA, A.L. e A.C. RAVELo. Climatologia y Fenologia Agrícolas. Buenos Aires, EUDEBA, p. 201-209.

DIAS, M.F., 1959. A variedade na renovação dos vinhedos riograndenses. Agronomia Sulriograndense. Porto Alegre, 4: 43-55.

DIAS, M.F., U.A. CAMARGO, J.L. LOVATEL e F. MANDELli, 1982. A cultivar de videira Sémillon: características e comportamento no Rio Grande do Sul. Bento Gonçalves, EMBRAPA/UEPAE de Bento Gonçalves/ IPAGRo/Secretaria de Agricultura do Rio Grande do Sul. 35 p. (Série Circular Tëcnica, 8).

DUNKEL, Z., J. FUtRI e F. KOZMA, 1980. Temperature and radiation requi rements of grapevines. A szolo hömërsékletés sugärzásigénye. Kertgazdasäg 12: 67-80. Apud: Horticultural Abstracts, Maidstone, 51 (9): 602,1981 .

EMPRESA BRASILEIRA DE PESQUISA AGROPECUÄRIA. Departamento Técnico-Cien tífico, 1981. PNP Viticultura. Brasilia, EMBRAPA/DID. 38 p. 
EMPRESA BRASILEIRA DE PESQUISA AGROPECUARIA. Unidade de Execução de Pesquisa de Âmbito Estadual, 1982. Relatörio Tëcnico Anual - 1981. Bento Gonçalves, EMBRAPA/UEPAË-BG. 150 p.

EMPRESA BRASILEIRA DE PESQUISA AGROPECUÄRIA. Unidade de Execuçäo de Pesquisa de Ámbito Estadua1, 1983. Relatörio Ténico Anual - 1982. Bento Gonçalves, EMBRAPA/UEPAE-BG. 92 p.

EMPRESA CATARINENSE DE PESQUISA AGROPECUĀRIA, 1978. Zoneamento Agroclimático do Estado de Santa Catarina. Porto Alegre, Ed. Pallotti, $150 \mathrm{p}$.

FABER, J., 1971. Caractéristiques bioclimatiques des cépages et des vignobles-Luxembourg. In: XIII Congres International de la Vigne et du Vin. Anais. Mendoza, Office International de la Vigne et du Vin, 1: 2-7.

FREITAS, A.G.B. de e A.M. GRĀCIO, 1971. Caractëristiques bioclimatiques des ceppages et des vignobles - Portugal. In: XIII Congres International de la Vigne et du Vin. Anais. Mendoza, Office Interna tional de 1 a Vigne et du Vin, 1 : $2-45$.

FUNDAÇÃO EDUCACIONAL DA REGIÃO DOS VINHEDOS. Instituto de Planejamento e Pesquisa, Bento Gonçalves, 1978. Hierarquia sócio-econômica das indüstrias dos principais municipios da Encosta Superior da Serra do Nordeste. FERVI, 84 p.

GALET, P., 1983. Précis de viticulture. 4. ed. Montpel1ier, Imprimerie Dëhan. $584 \mathrm{p}$.

GoBBATO, C., 1940. Manual do vitivinicultor brasileiro. Porto Alegre, Livraria Globo. 19. V. 422 p. 
GOLODRIGA, P., 1971. Caractëristiques bioclimatiques des cépages et des vignobles - U.R.S.S. In: XIII Congres International de la Vigne et du Vin. Anais. Mendoza, Office International de la Vigne et du Vin, $1: 2-12$.

GRÁCIO, A.M., 1971. A região vitícola de Alvito, Cuba e Vidigueira (seu passado, presente e futuro); Esboço de uma demarcação vitícola. Centro Nacional de Estudos Vitivinícolas. Lisboa, 18 p.

HIDALGO, L., 1956. Equivalentes meteorologicos de la vid. INIA. Madrid, 16: 175-209.

HIDALGO, L., 1980. Caracterización macrofisica del ecosistema medio-planta en los viñedos españoles. INIA. Madrid, 29: 1-255.

HIDALGO, L. e M.R. CANDELA, 1971. Caractēristiques bioclimatiques des cépages et des vignobles - Espagne. In: XIII Congres International de la Vigne et du Vin. Anais. Mendoza, Office International de la Vigne et du Vin, 1: 2-51.

HUGLIN, P., 1971. Caractéristiques bioclimatiques des cépages et des vignobles - France. In: XIII Congres International de la Vigne et du Vin. Anais. Mendoza, Office International de la Vigne et du Vin, $1:$ : 2-20.

KOKHANOVA, L.T., 1972. The effect of temperature on the duration of the second growth phase in grapevines. Nauchnye Trudy, Severo-Kavkazskii Zonal'nyi Nauchno Issledovatel'skii Institut Sadovodstva i Vinogradarstva, $\underline{2}$ : 338-346. Apud: Horticultural Abstracts, Maidsto ne, $44(10): 668,1974$. 
LEDESMA, N.R., 1950. Consecuencias del frio invernal insuficiente en los arboles de follage caduco. Rev. de la Facultad de Agronomia de 1a Plata. Buenos Aires, 27: 181-196.

LEMOS, R.C. de, M.A.D. AZOLIN, P.U. R. ABRÄO, M. da C.L. dos SANTOS e A.M. de CARVALHO, 1967. Levantamento de reconfiecimento dos solos do Estado do Rio Grande do Su1. Primeira etapa, planalto rio-grandense. Pesquisa Agropecuäria Brasileira. Rio de Janeiro, 2: 71-209.

LINDSEY, A.A. E J.E. NEWMAN, 1956. Use of official weather data in spring time-temperature analysis of an Indiana phenological record. Ecology. Durham, 37: 812-823.

MARTIN, T., 1971. Caractëristiques bioclimatiques des cépages et des vignobles - Roumanie. In: XIII Congres International de la Vigne et du Vin. Anais. Mendoza, Office International de la Vigne et du Vin, 1 : $2-12$.

MORENO, J.A., 1961. Clima do Rio Grande do Sul. Porto Alegre, Secretaria da Agricultura. 42 p.

MOTA, F.S. da, 1957. Os invernos de Pelotas-RS, em relação às exigências das ärvores frutiferas de folhas caducas. Pelotas, MA/IPEAS. 38 p. (Série Boletim Técnico, 18).

MULLNER, L., 1971. Caractëristiques bioclimatiques des cépages et des vignobles - Autriche. In: XIII Congres International de la Vigne et du Vin. Anais. Mendoza, Office International de la Vigne et du Vin, I: $2-4$. 
NEGROUL, A.M., 1965a. Les rythmes des përiodes vëgétatives et de repos chez la vigne. Le Progrés Agricole et Viticole. Paris, 82 : 47-51.

NEGROUL, A.M., 1965b. Les rythmes des périodes végétatives et de repos chez la vigne. Le Progrés Agricole et Viticole. Paris, 82 : 104-111.

NEMETH, M., 1972. Caractëristiques écologiques des cépages et des vig nobles - Hongrois. Bulletin de I'Office International de la Vigne et du Vin. Paris, 45: 25-43.

NITSCH, J.P., 1957. Photoperiodism in woody plants. Proceedings of the American Society for Horticultural Science. New York, 70: 526-544 .

PAGLIARI, M., 1980. L'indice di De Martonne e la qualitá dell'annata vinicola. Vignevini. Bologna, $7: 27-30$.

PAI ANISWAMY, K.P., S. KRISNAMURTHI e V.N.M. RAO, 1965. Influence of certain climatic factors on the quality of grapes. South. Indian Horticulture. Coimbatore, 13: 1-15.

POUGET, R., 1966. Étude du rythme végétatif: caractéres physiologiques liés a la précocité de débourrement chez la vigne. Annales Amélioration des plantes. Paris, 16: 81-100:

POUGET, R., 1967. Méthode d'appréciation de 1'évolution physiologique des bourgeons pendant la phase de prë-dëbourrement: application à 1 'étude comparée du débourrement de la Vigne. Vitis. Siebelding, $\underline{6}$ : 294-302. 
POUGET, R., 1969. Etude méthodologique de la précocité relative de dëbourrement chez la vigne. Annales Amélioration des Plantes. Paris, 19: $81-90$.

POUGET, R., 1972. Considérations gēnérales sur le rythme végétatif et la dormance des bourgeons de la vigne. Vitis. Siebelding, 11: 198-217 .

PRIMAULT, B., 1969. D'une application pratique des indices biométéoro logiques. Agricultura1 Meteorology. Amsterdam, 6: 71-96.

REDONDO, A.L., 1973. E1 año meteorológico y la cosecha de uva. La Semana Vitivinícola. Valencia, 28: 265-271.

REDONDO, A.L., 1974. E1 año meteorológico y la cosecha de uva. La Semana Vitivinícola. Valencia, p. 1213-1219.

REDONDO, A.L., 1977. E1 año meteorológico y la cosecha de 1976 em Rio ja. La Semana Vitivinícola. Valencia, p. 611-615.

RIBAS, W.C., 1962. Observações sobre as possibilidades da viticultura no Mëdio São Francisco. Campinas, IAC. 27 p. (Sërie Boletim Técnico, 125).

RIO GRANDE DO SUL. Programa de investimentos integrados para o setor agropecuärio, 1975. Zoneamento agrícola. Porto Alegre, 303 p.

RIO GRANDE DO SUL. Secretaria da Agricultura. Unidade de Enologia, 1977. Relação de estabelecimentos registrados. Porto Alegre, Secretaria da Agricultura, 34 p. 
RIO GRANDE DO SUL. Secretaria da Agricultura, 1978. Cuidados para ob ter uma boa produção de uvas. Lavoura Pecuāria. Porto Alegre, 5: $22-27$.

RIZZON, L.A. e J. TONIETTO, 1982. Os fatores climáticos e a qualidade da safra vitícola de 1982 na MRH311-Vinicultora de Caxias do Sul. Bento Gonçalves, UEPAE/BG, $9 \mathrm{p}$.

ROSA FILHO, T.P. da, 1973. Competição de métodos para aumentar o teor de açücar nas uvas amadurecidas sob condições chuvosas e de baixa luminosidade. In: II Congresso Brasileiro de Fruticultura. Anais. Viçosa, Sociedade Brasileira de Fruticultura, 2. 502-512.

SAFRAN, B. e N. HOCHBERG, 1971. Caractéristiques bioclimatiques des cépages et des vignobles - Israel. In: XIII Congres International de la Vigne et du Vin. Anais. Mendoza, Office International de la Vigne et du Vin, 1: 2-19.

SAMISH, R.M., 1954. Dormancy in woody plants. Am. Rev. of Plant Physiology. California, 5: 183-201.

SANTOS, R.S.B. dos, 1966. Fitoclimograma esquemático da videira no Brasil. Revista Brasileira de Geografia. Rio de Janeiro, 28: 113-127 .

SEGUIN, G., 1980. Influence des facteurs naturels sur les caractères des vins. In: RIBEREAU-GAYON, J. e E. PEYNAUD. Sciences et techniques de la vigne. Paris, Dunod. V. I. 
SIMON, J.L. e W. KOBLET, 1978. Choix des systëmes culturaux de la vig ne, en fonction des contraintes climatiques (altitude et latitude). Bulletin de l'Office International de la Vigne et du Vin. Paris, 51 : $329-334$.

SOUZA, J.S.I. de, 1969. Uvas para o Brasil. Säo Paulo, Me1horamentos. $454 \mathrm{p}$.

STAEHELIN, M., A. JAQUINET e J.L. SIMON, 1970. Particularités du climat et comportement de la vigne. Revue Suisse de Viticulture et d'arboriculture. Lausanne, 2 : 14-19.

STOEV, K., K. KATEROV e A. DONTCHEV, 1971. Caractëristiques bioclimatiques du cépages et des vignobles - Bulgarie. In: XIII Congres International de la Vigne et du Vin. Anais. Mendoza, Office Inter national de la Vigne et du Vin, 1: 2-16.

TABUENCA, M.C., 1965. Influencia del clima en plantaciones frutales. Bu1. Consejo Superior de Investigaciones Cientificas. Zaragosa, 8 : $55-63$.

TAMARo, D., 1920. Tratado de fruticultura. Traduçăo de A. CABALLERo. Barcelona, Editora Gustavo Gili. 933 p.

TRIPOLI, M.J. de 0. e, e L. MULLER, 1981. Desenvolvimento do fruto em algumas cultivares de videira no Rio Grande do Sul. Agronomia Sulriograndense. Porto Alegre, 17: 305-339.

UNIÃo BRASILEIRA DE VITIVINICULITURA, Porto Alegre, 1977 . Produção vinícola comerciāvel no Rio Grande do Sul. UVIBRA, 8p. 
VAN DEN BRINK, C., 1974. 'Predicting harvest date of the 'Concord' gra pe crop in southwest Michigan. HortScience, Alexandria, Virginia, 9: 206-208.

VASCONCELLOS, P.W.C. de, 1930. Subsidios a ampelografia nacional. Piracicaba, Livraria Giraldes. $71 \mathrm{p}$.

VEGA, J., 1969. Factores que condizionan la cantidad y calidad en la producción de uva. IDIA. Mendoza, 261: 9-56.

VERDEREVSKIY, D., 1962. Services d'avertissements contre les accidents météorologiques et les attaques parasitaires de la vigne. Bulletin de 1'Office International de 1 a Vigne et du Vin. Paris, 35: 715-724 .

VERES, A., 1971. Caractëristiques bioclimatiques des cépages et des vignobles - Tchecoslovaquie. In: XII Congres International de $1 \mathrm{a}$ Vigne et du Vin. Anais. Mendoza, Office International de la Vigne et du Vin, 1: 2-13.

VERES, A. e A. VALACHOVIC, 1978. Observations phēnologiques et mesures bioclimatiques dans plusieurs sites viticoles tchéques à différentes altitudes en vue de la délimitation de l'aire viticole. Bulletin de 1'Office International de la vigne et du Vin. Paris, 51: $78-86$.

VILlA NOVA, N.A. e J.C. OMETTO, 1978. "Cälculo da duração do dia. (N) no intervalo compreendido entre $5^{\circ}$ de latitude norte ate $35^{\circ}$ de 1 titude su1". In: II Congresso Latino-Americano de Energia Solar. Anais. João Pessoa. 70 p. (Anexo 50 A). 
VILLA NOVA, N.A., M.J.P. JUNIOR, A.R. PEREIRA E J.C. OMETTO, 1972. Es timativa de graus-dia acumulados acima de qualquer temperatura base, em função das temperaturas mảxima e mínima. Ciências da Terra. São Paulo, 30: 1-8.

VLACHOS, M., 1971. Caractéristiques bioclimatiques des cépages et des vignobles - Grece. In: XIII Congres International de la Vigne et du Vin. Anais. Mendoza, office International de la vigne et du Vin, $1: 2-19$.

WESTPHALEN, S.L., 1977. Bases ecolögicas para determinação de regiões de maior aptidão vitícola no Rio Grande do Sul. In: I Simpósio la tino-americano de la uva y del vino. Anais. Montevidéo, Ministério de Industria y Energia, Laboratörio Tecnológico del Uruguay, 1: 89-101. (Cuaderno Tëcnico, 38).

WESTPHALEN, S.L., 1980. 'Anālise dos critérios dos zoneamentos para a viticultura no Rio Grande do Sul e Santa Catarina. In: V Encontro de Atualização Vitivinícola, Bento Gonçalves, FERVI, 15 p.

WINKLER, A.J., 1965. Viticultura. México, Compañia Editorial Continental. $792 \mathrm{p}$.

WINKLER, A.J., J.A. COOK, W.M. KLIEWER e L.A. LIDER, 1974. General Viticulture. Berkley, University of California Press. 710 p.

ZULUAGA, P.A., E.M. ZULUAGA, J. LUMELli e F. de 1a IGLESIA, 1970. Metodologia para la classificación de zonas o regiones viticolas. OLAVU, Buenos Aires, 1: 9-27.

ZULUAGA, P.A., E.M. ZULUAGA, J. LUMELLI e F.J. de la IGLESTA, 1971 . Ecologia de la vid en la Republica Argentina. Mendoza, Compañia Ipsilön. $149 \mathrm{p}$. 